\title{
Income from apples in the eastern panhandle : Factors contributing to profitable orchard management
}

Martin A. Abrahamsen

Follow this and additional works at: https://researchrepository.wvu.edu/ wv_agricultural_and_forestry_experiment_station_bulletins

\section{Digital Commons Citation}

Abrahamsen, Martin A., "Income from apples in the eastern panhandle : Factors contributing to profitable orchard management" (1947). West Virginia Agricultural and Forestry Experiment Station Bulletins. 328.

https://researchrepository.wvu.edu/wv_agricultural_and_forestry_experiment_station_bulletins/331 @ WVU. It has been accepted for inclusion in West Virginia Agricultural and Forestry Experiment Station Bulletins by an authorized administrator of The Research Repository @ WVU. For more information, please contact ian.harmon@mail.wvu.edu. 
West Virginia University Libraries

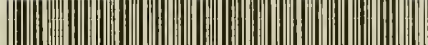

|||||||||.|||||||||||||||||||||||||||||||||||||.|||||||||||||||||||||||||||||

$\begin{array}{lll}3 & 0802100896127 & 1\end{array}$ 
Digitized by the Internet Archive in 2010 with funding from

Lyrasis Members and Sloan Foundation

http://www.archive.org/details/incomefromapples328abra 


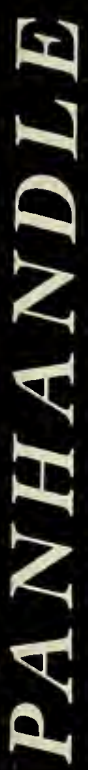

630.75
$0.5, b$
$\cos 20$

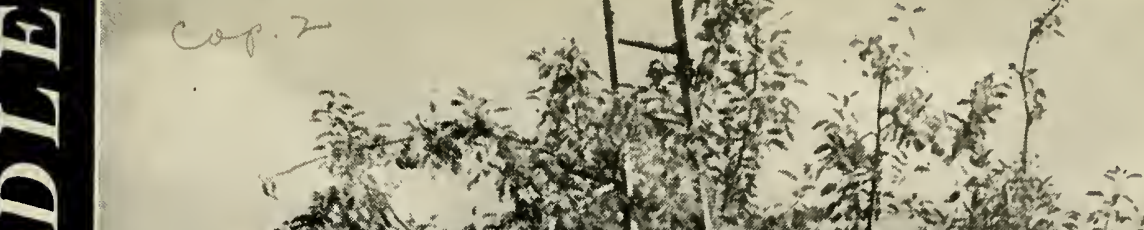

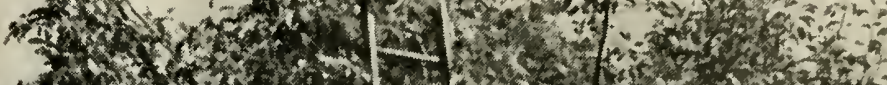

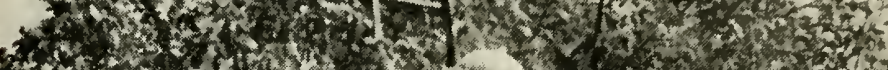

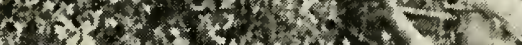

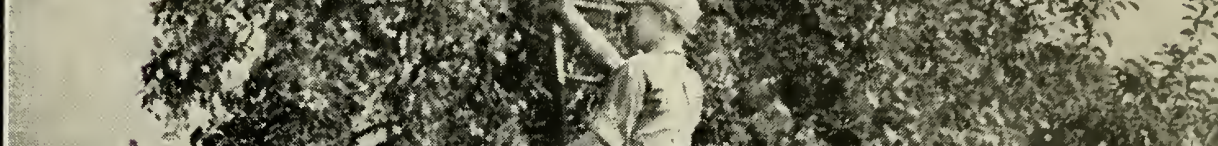

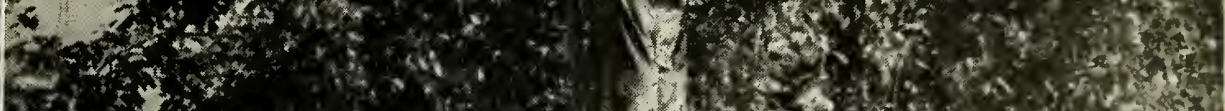

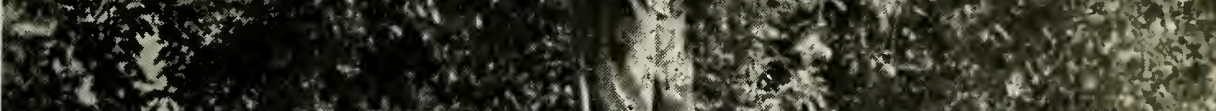

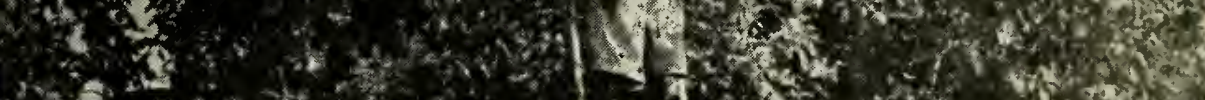

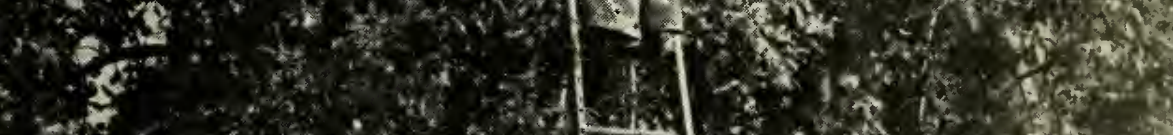

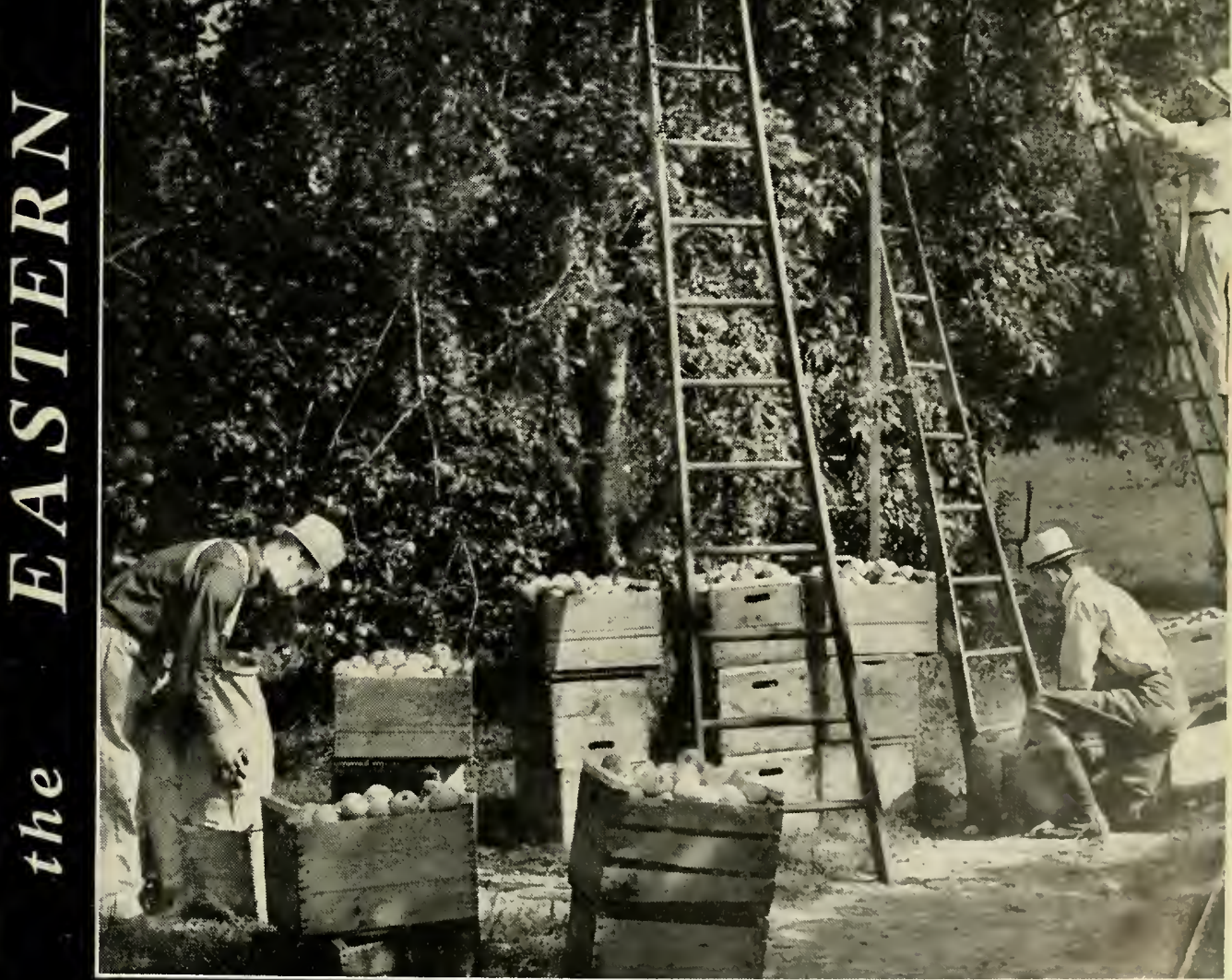

M. A. Abrahamsen

Agricultural Experiment Station Moreantown. West Virainia 


\section{LIST OF ILLUSTRATIONS}

Fig. 1-Number of Trees of Bearing Age Reported by Counties in West Virginia, 1900 and 1940.

Fig. 2-Relationship of Farm Returns from Commercial Apple Production to Income of Nonagricultural Workers, 1919-1944

Fig. 3-Pruning Practices. Pruning is an important part of cultural operations. Skill in this task does much to determine spraying costs, quality of fruit packed, and production for the years ahead.

Fig. 4-Spraying Operations. Good equipment, intelligent selection of spray materials, and timeliness of application do much to enable growers to obtain effective disease and insect control.

Fig. 5-Apple Picking. Skill in this operation is essential if bruising of apples is to be avoided and if fruit is to be picked and packed at right degree of maturity........

Fig. 6-Packing Practices. Packing has become a highly specialized operation that does much to determine the quality of fruit available for consumption.

Fig. 7-Storage Operations. Local and commercial storage operations have become an important part of orchard operations in the Eastern Panhandle of West Virginia..

Fig. 8-Orchard Facilities. Pictured is a combination applepacking shed, storage plant, and general utility building. Facilities of this nature explain why investments in orcharding are high

AGRICULTURAL EXPERIMENT STATION

COLLEGE OF AGRICULTURE, FORESTRY, AND HOME ECONOMICS

WEST VIRGINIA UNIVERSITY

C. R. ORTON, Director

MORGANTOWN 


\section{CONTENTS}

Purpose and method of study $\ldots \ldots \ldots \ldots \ldots \ldots \ldots \ldots \ldots$

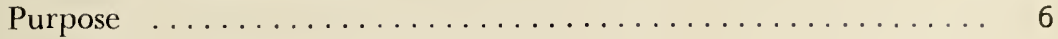

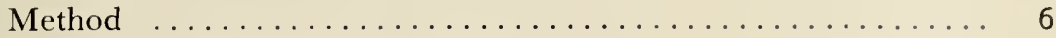

Importance of apples in West Virginia agriculture $\ldots \ldots \ldots \ldots \ldots \quad 7$

Apple income and production .................... 7

Comparison with other types of farming and size of farm operation 9

Economic considerations influencing the place of apples in the agricul-

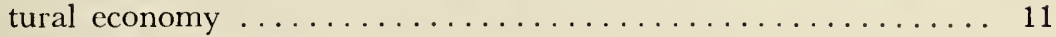

Trends within the apple industry $\ldots \ldots \ldots \ldots \ldots \ldots \ldots \ldots \ldots, 11$

Changes in the number of trees $\ldots \ldots \ldots \ldots \ldots \ldots \ldots \ldots 11$

Production and income ..................... 13

Competition from other fruits $\ldots \ldots \ldots \ldots \ldots \ldots \ldots \ldots \ldots \ldots$

Fresh fruits .......................... 14

Canned fruits .......................... 14

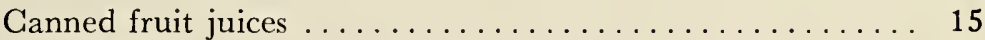

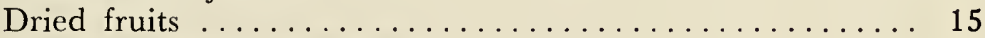

Other fruits and vegetables $\ldots \ldots \ldots \ldots \ldots \ldots \ldots \ldots \ldots, 15$

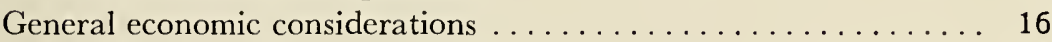

Consumer purchasing power $\ldots \ldots \ldots \ldots \ldots \ldots \ldots \ldots, 16$

Foreign trade in apples ................... 16

Costs and returns from apple production $\ldots \ldots \ldots \ldots \ldots \ldots \ldots \ldots$

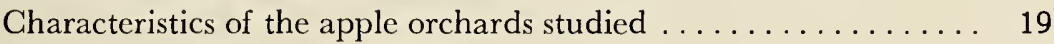

Costs, returns, and investments ................. 20

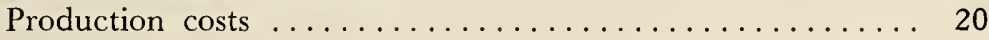

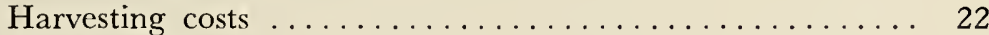

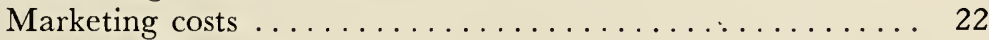

Overhead costs ........................ 22

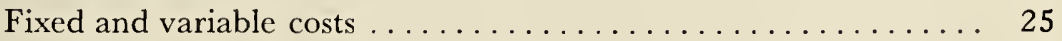

Cash and noncash costs $\ldots \ldots \ldots \ldots \ldots \ldots \ldots \ldots \ldots \ldots$

Significant features of selected orchards ............... 28

Most profitable and least profitable orchards ........... 29

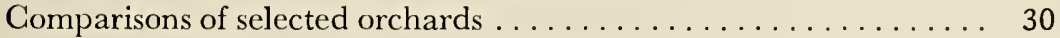

Factors contributing to profitable apple production . . . . . . . . 34

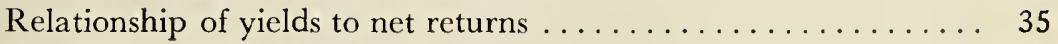

The influence of soil series . . . . . . . . . . . . . . . . 38

Comparison of shale and limestone soils . . . . . . . . . 38

Comparison of Frankstown and Hagerstown limestone soils . . . 39

Relationship of erosion to orchard performance ......... 41

The relationship of size of orchard operations to profitability .... . 41 
Influence of selected operating practices ............. 42

Variety plantings of bearing and nonbearing trees ....... 42

Number of trees per acre of bearing apples ........... 43

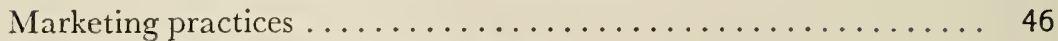

The role of local apple storages . . . . . . . . . . . . 46

Methods of sale ..................... 47

The growing complexity of problems of marketing ...... 48

The role of management . . . . . . . . . . . . . . . 49

Selected operating practices showing the influence of management ......................... 49

The use of labor and capital resources .............. 51

Characteristics of management contributing to successful orchard operation ................... 52

Orchard development costs and depreciation $\ldots \ldots \ldots \ldots \ldots \ldots \ldots 54$

Development costs ...................... 54

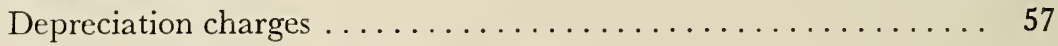

Production-unit method of depreciation $\ldots \ldots \ldots \ldots \ldots \ldots \ldots .59$

Summary and conclusions ...................... 63 


\title{
INCOME FROM APPLES IN THE EASTERN PANHANDLE (Factors Contributing to Profitable Orchard Management)
}

\author{
by \\ M. A. ABRAHAMSEN
}

SIGNIFICANT CHANGES have characterized the management of apple $S$ orchards in the Eastern Panhandle of West Virginia. Since the turn of the century, production practices have been influenced by the introduction of new and improved varieties, marked changes in cultural techniques, development of serious insect and disease problems, and mechanization of many operations. Harvesting methods have placed special stress on the need for avoiding bruises and thereby preserving the quality of apples produced. Consequently increased attention has been given to picking methods, to packing procedures, and to other problems associated with harvesting. Marketing practices have been modified by such factors as the trend toward individual ownership of local storage facilities, "fresh packing" (packing apples from storage at the time of sale as contrasted with the usual practice of packing at picking time), changes in types of containers, truck transportation, and constant modification in the character of marketing agencies available to growers and in the services they render. In addition some of the more general factors affecting the marketing of apples, and consequently the price that farmers receive for them, include the changing status of world trade, trends in consumer purchase power, and the influence of competition from other fruits.

Note: This study was undertaken as a joint project by the Departments of Agricultural Economics, Horticulture, and Plant Pathology of the Agricultural Experiment Station, West Virginia University. The Department of Horticulture has given attention to tree condition and fruit bruising, and the Department of Plant Pathology to tree condition and the relationship of spraying practices to fruit condition; the Department of Agricultural Economics has had responsibility for the assembling and analysis of financial data. In addition the Land Appraisal Division of the Farm Credit Administration, Washington. D. C., mapped approximately 50 orchards from which selections were made for detailed study. Maps of individual orchards were prepared. showing soil type, degree of erosion, slope, and variety plantings.

The study was requested by apple growers in the Eastern Panhandle and planned by Professor W. W. Armentrout, head, Department of Agricultural Economics. and by Dr. F. D. Fromme, formerly director of the West Virginia Agricultural Experiment Station. Acknowledgment is gratefully expressed to the following individuals who read this study in preliminary form and who offered many valuable suggestions: Professors Armentrout, R. H. Sudds, and C. F. Taylor, and Mr. Hugh Prettyman, all of the College of Agriculture, West Virginia University; Mr. George Miller of the Land Appraisal Division. Farm Credit Administration; Mr. Carroll R. Miller. secretary of the West Virginia Horticultural Society: Mr. Henry W. Miller. Jr., and Mr. Paul Hawkins, apple producers; Mr. Malcolm Brown, distributor; and Mr. David Volkin, manager. Fruit Growers Cooperative Storage Association, Eastern Panhandle of West Virginia.

Mr. W. Keith Lanham (deceased) and Mr. Volkin served as field agents in assembling financial records. Valuable assistance in statistical analysis was given by Mr. V. O. Havener. Mr. Volkin also assisted in this capacity during early stages of the study. Miss Margaret Cross and Mrs. Martha Frowen assisted in a clerical capacity. Mr. David Nellis was responsible primarily for mapping variety plantings. Grateful appreciation also is expressed to the many growers who have given time and have extended wholehearted cooperation in making data and information available.

For photographs the author is indebted to $\mathbf{M r}$. W. M. Nelson of the Agricultural Experiment Station and to Mr. Carroll R. Miller. 


\section{PURPOSE AND METHOD OF STUDY}

\section{Purpose}

The many changes taking place in the management of apple orchards call for a reexamination of the operating practices followed by growers. This study therefore aims to determine the relationship of various economic, managerial, physical, cultural, and climatic factors to profitable orchard management. More specifically attention is given to the following items:

1. Determining the importance of the apple industry in West Virginia agriculture.

2. Evaluating some of the more important economic considerations that influence the place of the apple industry in the agricultural economy.

3. Ascertaining costs and returns of apple production for the period 1938-1941 and for individual years within this period.

4. Appraising orchard-management practices from the standpoint of:

A. Relationship of soil type to profitable operation.

B. Determination of the relationship of net returns to selected operating practices.

C. Relationship of tree and fruit condition to insect and disease-control measures.

5. Considering the influence of marketing methods and orchard development costs as factors in profitable operation.

6. Presenting suggestions for improvement in orchard-management practices. ${ }^{1}$

The ability of growers to appraise changes in production, harvesting, and marketing operations will do much to determine the profitableness with which they may engage in apple production. Since findings of this study apply to the pre-war period of 1939-1941, they should be of assistance to orchardists as the apple industry adjusts to conditions of a post-war economy. It is hoped that the information made available will serve as guideposts for helping growers compare their operating performance with pre-war conditions as well as for planning future operations.

\section{Method}

To obtain general information as to the nature and extent of orchard operations in the Eastern Panhandle of West Virginia, a preliminary study of apple farms was undertaken in the summer of $1937 .{ }^{2}$ This study was particularly helpful in:

1. Furnishing information as to the types of orchard operations prevailing in the territory studied.

\footnotetext{
'While this item is outside the scope of this study, it is recognized that many factors affecting profitable orchard operation are beyond the direct influence of individual growers. They are in every respect as important, however, as the orchard-management factors stressed in this report. Examination of the past issues of the "Mountaineer Grower," the official publication of the West Virginia Horticultural Society, indicates the nature of many of the important economic problems that have received and are receiving the attention of growers through joint action. Some of these issues include references to crop estimates, freight rates, production adjustments, package standardization, government programs for assistance of growers (tree removal, apple purchasing, price supports, and price ceilings), storage problems, sales promotion and consumer preference for apples, and apple byproducts and processing-plant operations. It is largely through group action and agencies of government that growers can make their influence felt regarding many of these problems and such closely related items as elimination of barriers to internal and foreign trade, encouragement of sound and efficient marketing systems, reduction of wholesale and retail marketing margins, and improvements in grading techniques.

${ }^{2}$ M. A. Abrahamsen, A Labor Income Study of Orchard Farms in the Eastern Panhandle of West Virginia (with special reference to apple production), W. Va. Agr. Expt. Sta. Mim. Cir. No. 27. Jan. 1938.
} 
2. Indicating the need for giving careful attention to such factors as soils, varieties, and climatic considerations in establishing orchards and in demonstrating the practicability of various cultural practices once orchards were started.

3. Serving as a basis in selecting orchards for more intensive study.

Supplementary studies helpful in furnishing background information have dealt with labor incomes of apple growers for 1937. These include a summarization of apple trees according to variety and age, packing-house operations, local refrigerated storages, orchard depreciation, and 1943 costs and returns from selected orchards. ${ }^{3}$

In 1938, operators of approximately 50 orchards in the Eastern Panhandle began cooperating in a long-time study of orchard costs and returns (19381941). It was not possible always to select cooperating growers in direct proportion to the various physical and economic factors that made their influence felt in the area. Indications are, however, that those growers participating in this study were in position to furnish valuable information relative to problems that are important in determining profits or losses from orchard operations.

In most instances financial data have been supplemented with information pertaining to:

1. Detailed soil maps showing soil type, topography, extent of erosion, and tree counts according to variety and age.

2. Cultural history and prevailing managerial practices.

3. Information relating to tree condition, planting schemes, and climatological data concerning frost pockets.

4. Disease and insect-control problems and practices.

Records of costs and returns were kept under the direction of a fieldman. Because of the varying nature of year-to-year costs and returns, it was believed that no consideration relating to the economics of orchard management would be adequate or would give a true picture of the status of the industry that did not attempt to furnish information based on long-time studies that serve to level out the inherent fluctuations that characterize yearly apple-production data. The section dealing with costs and returns gives further indication of techniques used and methods followed in analyzing data.

\section{IMPORTANCE OF APPLES IN WEST VIRGINIA AGRICULTURE ${ }^{4}$}

\section{Apple Income and Production}

Apples are the most important cash crop in West Virginia. During the period 1938-1941, the years covered in this study, they accounted for 8.1 percent of the cash farm income of the state. This represented an average yearly

${ }^{3}$ See (1) M. A. Abrahamsen and W. Keith Lanham, Apple Production Costs and Returns in the Eastern Panhandle of West Virginia, Mim. Cir. No. 35-A. March 1939; (2) R. S. Marsh and M. A. Abrahamsen, Apple Varieties and the Age of Trees, Mim. Cir. No. 36. March 1939; (3) David Volkin and M. A. Abrahamsen, Packing-House Operating Costs in the Eastern Panhandle of West Virginia, 1938 Crop Year, Mim. Cir. No. 39. Sept. 1939; (4) David Volkin and M. A. Abrahamsen, Refrigerated Storage Plants in the Eastern Panhandle of West Virginia, Mim. Cir. No. 43. Dec. 1940-All published by the Agricultural Experiment Station, West Virginia University; (5) M. A. Abrahamsen, Orchard Depreciation-A Long Neglected Expense Item, American Fruit Grower, Jan. 1944; and (6) M. A. Abrahamsen, Costs of Producing Apples, 1943; Mountaineer Grower, March-April 1944 .

${ }^{4}$ In his study, An Apple Orchard Survey of Berkeley County, W. Va. Agr. Expt. Sta. Bul. No. 151. June 1914, Professor E. C. Auchter reports on the early beginnings of apple production in West Vir- 
sum of nearly 3.5 millions of dollars and amounted to about 30 percent of the cash income from all crops. Although cash farm income in 1944 was about twice the 1938-1941 average, the relative importance of the major crops, including apples, remained much the same (Table 1).

TABLE 1-Sources of Cash Farm Income in West Virginia, 1938-1941 and $1944^{1}$

\begin{tabular}{|c|c|c|c|c|c|c|}
\hline \multirow[b]{3}{*}{ Source of income } & \multicolumn{3}{|c|}{ Yearly average $1938-1941$} & \multicolumn{3}{|c|}{$1944^{2}$} \\
\hline & \multirow[b]{2}{*}{ Amount } & \multicolumn{2}{|c|}{ Percentage of: } & \multirow[b]{2}{*}{ Amount } & \multicolumn{2}{|c|}{ Percentage of: } \\
\hline & & $\begin{array}{c}\text { Total } \\
\text { cash } \\
\text { income }\end{array}$ & $\begin{array}{c}\text { Cash } \\
\text { income } \\
\text { from crops }\end{array}$ & & $\begin{array}{l}\text { Total } \\
\text { cash } \\
\text { income }\end{array}$ & $\begin{array}{c}\text { Cash } \\
\text { income } \\
\text { from crops }\end{array}$ \\
\hline & $\begin{array}{r}1,000 \\
\text { dollars }\end{array}$ & percent & percent & $\begin{array}{c}1,000 \\
\text { dollars }\end{array}$ & percent & percent \\
\hline \multicolumn{7}{|l|}{$\begin{array}{l}\text { Crops } \\
\text { Fruits and vegetables }\end{array}$} \\
\hline Apples & 3,435 & 8.1 & 29.4 & 6,376 & 7.2 & 26.3 \\
\hline Potatoes & 919 & 2.2 & 7.9 & 3,287 & 3.7 & 13.5 \\
\hline Other & 2,809 & 6.6 & 24.0 & 4,188 & 4.8 & 17.3 \\
\hline $\begin{array}{c}\text { Total } \\
\text { Othex crops }\end{array}$ & $7, \overline{163}$ & 16.9 & 61.3 & 13,851 & 15.7 & 57.1 \\
\hline Other crops & 4,526 & 10.7 & 38.7 & 10,388 & 11.8 & 42.9 \\
\hline \multirow{2}{*}{$\begin{array}{c}\text { Total all clops } \\
\text { Livestock and livestock } \\
\text { products }\end{array}$} & 11,689 & 27.6 & 100.0 & 24,239 & 27.5 & 100.0 \\
\hline & 30,688 & 72.4 & . & 63,769 & 72.5 & $\ldots$ \\
\hline Total all items & 42,377 & 100.0 & $\ldots$ & 88,008 & 100.0 & $\ldots$ \\
\hline
\end{tabular}

${ }^{1}$ Compiled from data published by the West Virginia Crop and Livestock Reporting Service. Government payments are not included.

'Preliminary.

Apple growing in West Virginia is a highly commercialized industry. As a general rule about 60 percent of the total production finds its way into channels of trade. Commercial production, in turn, accounted for about 80 percent of the gross farm income from apples. As closely as can be determined, about 85 percent of returns comes from the sale of commercial apples from the Eastern Panhandle." The remainder primarily is from the Ohio Valley-principally Hancock and Mason Counties. Other commercial areas are decidedly localized in character and of relatively limited importance. Apple production is becoming increasingly concentrated in the Eastern Panhandle in comparison with other sections of the state. This is indicated by the fact that in 1939 that section reported 43.9 percent of the non-bearing trees as compared with but 38.1 percent of the bearing trees (Sixteenth Census of Agriculture).

ginia. He states that the first recorded planting of apples in the state took place at about the time of the Revolutionary War. In 1774 George Washington leased 125 acres of land to William Bartlett in the "Barrens of Bullskin," then a part of Berkeley County. The lease stipulated that the lessee "should within seven years plant one hundred winter apple trees, forty feet apart each way." He further reports that the first commercial orchard of fruit reported in West Virginia was planted in 1851, when Mr. W. S. Miller, a farmer near Gerrardstown, planted 16 acres of apples, peaches, and plums. This would establish commercial production at about the time of the Civil War. Since that time "Apple Pie Ridge" has become synonymous with apple production in the eastern part of the state. Fortunes have been made and lost in highly speculative apple-orcharding ventures, and some of the largest apple orchards in the country have become established in West Virginiaseveral being over 300 acres and one over 1,000 acres in extent.

From these early beginnings, such developments as shipping-point inspection and the establishment of Federal and state grades; shifts from barrels to baskets and boxes, including wrapping of a considerable proportion of the fruit; establishment of numerous apple-sales agencies (private and cooperative): growth of commercial and, more recently, individually owned and cooperative storage and byproduct establishments; and extensive trucking facilities to supplement rail transportation-these are some of the more recent economic trends in the apple industry of West Virginia.

"As used in this study, the term "Eastern Panhandle" is used broadly to comprise the counties of Jefferson, Berkeley, Morgan, Hampshire, and limited apple-producing areas in Mineral, Grant, and Hardy. 
A further measure of the importance of commercial apple production and cash farm income from apples in West Virginia for the period 1934-1944 may be noted by consideration of the following data:"

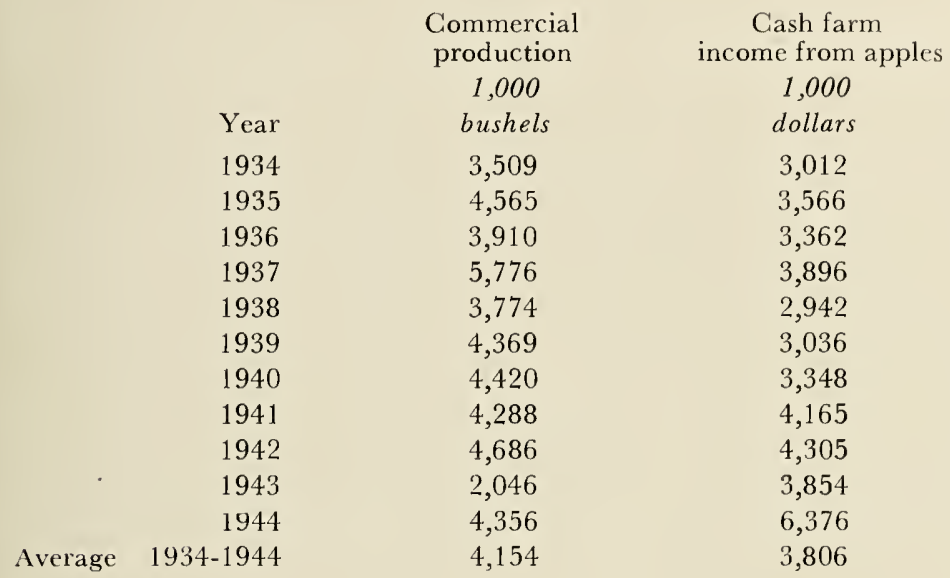

These data indicate that considerable variation exists from year to year in the apple industry. The influence of such factors as "off" and "on" years of production, seasonal variation in climatic conditions, trends in plantings, extent of orchard discontinuance, and conditions prevailing with respect to disease and insect outbreaks, all are important items in determining year-toyear production and income. These factors as well as such items as consumer income and foreign trade in apples have a marked influence on apple returns and consequently on the extent of profit derived or of loss sustained by growers.

\section{Comparison With Other Types of Farming, and Size of Farm Operations}

Some indication of the extent to which horticultural products are important on various types of farms in West Virginia may be obtained by examination of data presented in Table 2. While information is not available for a special classification of apple farms as such, except for a limited number of peach and cherry growers, operators in the "fruits and nuts and orchard specialties" class primarily are apple producers. A striking characteristic of these producers is the concentration of operations in a limited number of large farm holdings. It may be noted that the proportion of other types of farms that sell fruits and nuts and orchard specialties is low-for no group does it average over 17 percent. Fruits and nuts and horticultural specialties comprised 90.2 percent of all sales on farms in that classification. For all other types of farms, however, these items accounted for less than 2 percent of total sales (Table 2).

"Compiled from West Virqinia Aqricultural Statistics, W. Va. Dept. of Agr., Bul. N. C. No. 37 Included in production but not harvested for 1937 and 1940 , respectively, were 800,000 and 310,000 bushels of apples. It may be noted that for the five "off" yeat's (1934, 1936, 1938, 1941, and $1943)$ production was 16 percent below the average for the 1934-1944 period, and eash income was 9 percent below average. For" the six "on" year"s $(1935,1937,1939,1940,1942$, and 1944) production was 13 percent above the 1934-1944 average, and eash farm income from apples was 5 percent above average for the period. 
TABLE 2-Relations of Type of Farm to Percentage of Farmers Reporting Sales of Fruits and Nuts and Horticultural Specialties, Average Sales per Farm Reporting, and Proportion of Such Sales to Total Farm Sales, West Virginia, $1939^{1}$

\begin{tabular}{|c|c|c|c|c|c|}
\hline \multirow[b]{2}{*}{$\begin{array}{l}\text { Type of } \\
\text { farm }\end{array}$} & \multicolumn{2}{|r|}{ Farms } & \multicolumn{2}{|c|}{$\begin{array}{l}\text { Average sales per } \\
\text { farm for: }\end{array}$} & \multirow{2}{*}{$\begin{array}{l}\text { Percentage of } \\
\text { total sales } \\
\text { accounted for } \\
\text { by fruits and } \\
\text { nuts and or- } \\
\text { chard special- } \\
\text { ties }\end{array}$} \\
\hline & Total & $\mid \begin{array}{c}\text { Percentage of } \\
\text { total selling } \\
\text { fruits and nuts } \\
\text { and horticul- } \\
\text { tural specialties }\end{array}$ & $\begin{array}{l}\text { All farm } \\
\text { products }\end{array}$ & $\begin{array}{l}\text { Fruits and } \\
\text { nuts and } \\
\text { orchard } \\
\text { specialties }\end{array}$ & \\
\hline & number & percent & dollars & dollars & percent \\
\hline Livestock & 7,659 & 10 & 1,207 & 7 & 0.6 \\
\hline Dairy products & 2,486 & 17 & 2,144 & 22 & 1.0 \\
\hline Poultry & 2,263 & 17 & 949 & 13 & 1.4 \\
\hline Field crops & 2,882 & 13 & 690 & 10 & 1.4 \\
\hline Vegetables & 245 & . & 1,009 & $\ldots$ & .. \\
\hline Self-sufficing & 80,099 & 8 & 102 & 3 & 3.0 \\
\hline $\begin{array}{l}\text { Fruits and nuts and horticultural } \\
\text { specialties }\end{array}$ & 737 & 100 & 3,672 & 3,313 & 90 \\
\hline
\end{tabular}

${ }^{1}$ Compiled from the 16th Census of Agriculture, West Virginia, Third Series, p. 24.

Data presented in Table 3 indicate that a rather close relationship prevailed between size of operation and importance of the orchard enterprise. There is a definite concentration of orchard operations as the value of these products sold, traded, or used on farms increases. This is shown by the percentage of farmers selling or trading these products, average values of these items sold or traded per farm reporting, and percentage of total sales accounted for by fruits and nuts (Table 3 ).

TABLE 3-Relationship of Size of Farm Business to Proportion of all Farms Selling or Trading Fruits and Nuts, West Virginia, 1939 1

\begin{tabular}{|c|c|c|c|c|c|}
\hline \multirow[b]{2}{*}{$\begin{array}{l}\text { Size of farm } \\
\text { business } \\
\text { (Value of } \\
\text { products } \\
\text { sold, traded, } \\
\text { or used on } \\
\text { farms) }\end{array}$} & \multicolumn{3}{|c|}{ Farmers } & \multirow[b]{2}{*}{$\begin{array}{l}\text { Value of } \\
\text { fruit and } \\
\text { nuts sold } \\
\text { or traded } \\
\text { per farm } \\
\text { reporting }\end{array}$} & \multirow[b]{2}{*}{$\begin{array}{l}\text { Percentage } \\
\text { that sales or } \\
\text { trading of } \\
\text { fruits and } \\
\text { nuts are of } \\
\text { total farm } \\
\text { products sold } \\
\text { or traded }\end{array}$} \\
\hline & Total & $\begin{array}{c}\text { Selling or } \\
\text { trading } \\
\text { fruits and } \\
\text { nuts }\end{array}$ & $\begin{array}{c}\text { Percentage of } \\
\text { total selling } \\
\text { or trading } \\
\text { fruits and } \\
\text { nuts }\end{array}$ & & \\
\hline dollars & number & number & percent & dollars & percent \\
\hline Under 250 & 33,305 & 1,320 & 4 & 19 & 3.2 \\
\hline $250-399$ & 23,141 & 1,640 & 7 & 30 & 2.9 \\
\hline $400-599$ & 18,103 & 2,008 & 11 & 45 & 3.2 \\
\hline $600-3,999$ & 21,467 & 4,069 & 19 & 163 & 4.1 \\
\hline $4,000-9,999$ & 833 & 221 & 27 & 2,231 & 10.8 \\
\hline 10,000 -over & 210 & 73 & 35 & 14,043 & 24.6 \\
\hline Total & 97,059 & 9,331 & & & \\
\hline Average & . . . & $\ldots$ & 10 & 50 & 7.7 \\
\hline
\end{tabular}

${ }^{1}$ Compiled from the 16th Census of Agriculture, West Virginia, Third Series, p. 36.

In general the following observations may be made with respect to the commercial apple enterprise on West Virginia farms:

1. It is the most important cash crop in the state.

2. Production is concentrated on the larger farms and in the Eastern Panhandle.

3. Apples constitute the most important fruit crop in the state.

4. As a crop, apples are characterized by wide fluctuations in quality and quantity-a situation that seems inherent in production under West Virginia conditions. 


\section{ECONOMIC CONSIDERATIONS INFLUENCING THE PLACE OF APPLES IN THE AGRICULTURAL ECONOMY}

While this study primarily was designed to consider factors that contribute to profitable management of individual orchards, it is recognized that a wide variety of problems having their origin beyond the confines of the grower's "line fence" are very significant in the apple industry. It is becoming increasingly important, therefore, to recognize that many of the considerations that make their influence felt in determining the possibilities for profitable orcharding are beyond the scope of problems with which growers ean deal directly. Accordingly brief attention is given here to three of the more important of these problems before restricting attention to the financial analysis of orchards included in this study. These general considerations include: (1) trends within the apple industry, (2) the competitive position of apples, and (3) general economic matters.

\section{Trends Within the Apple Industry}

The more evident trends within the apple industry relate to: (1) changes in the number of trees (bearing and non-bearing) and (2) production and income. These factors are considered from the standpoint of the country as a whole, geographic areas (Eastern, Central, and Western),${ }^{7}$ and West Virginia.

Changes in the number of trees: ${ }^{8}$ Since 1910 a significant decrease has bren noticeable in the number of apple trees reported in the United States. The number of trees of bearing age has declined from 151,322,840 in 1910 to $58,152,108$ in 1940 - a decrease of slightly over 60 percent. Besides a general decline for the country as a whole, distinct trends have developed in the relative proportion of total trees reported for various geographic areas (for details sce Appendix Table A).

Further indication of trends in the number of apple trees of bearing age in various areas may be noted by consideration of the percentage that trees of bearing age in 1940 were of trees of bearing age in 1910, 1920, and 1930. For the United States these percentages were reported at 38, 50, and 65 percent, respeetively, for these periods. Furthermore, fluctuations in tree numbers were rather drastic in the various geographic areas until the decade of the 1930's, when greater stability in the relative position of the regions became noted.

As would be expected, the proportion of nonbearing trees was relatively higher shortly after the turn of the century because of extensive plantings and significant shifts in producing areas-particularly the development of commercial oreharding in the Western States. The industry, however, has attained a certain degree of maturity during the past two decades. (For an indication of trends in the number of trees of nonbearing and bearing age sec Appendix Table B.)

'As used in this report. the states comprising the various geographic areas were as follows: Eastern -Maine, New Hampshire. Vermont. Massachusetts, Rhode Island. Connecticut. New York. New Jersey, Pennsylvania, Delaware, Maryland, Virginia, West Virginia, North Carolina. South Carolina, Georgia, and Florida ; Central-Ohio, Indiana, Illinois, Michigan, Wiseonsin. Minnesota, Iowa, Missouri, Nebraska. Kansas. North Dakota, South Dakota, Kentucky, Tennessee, Alabama. Mississippi, Louisiana. Texas. Oklahoma, and Arkansas; and Western-Montana, Wyoming. Idaho, Colorado, New Mexico, Utah, Arizona, Nevada, Washington. Oregon, and California.

"Variations in methods of assembling census data may explain some of the differences in tree numbers from one census period to another. 

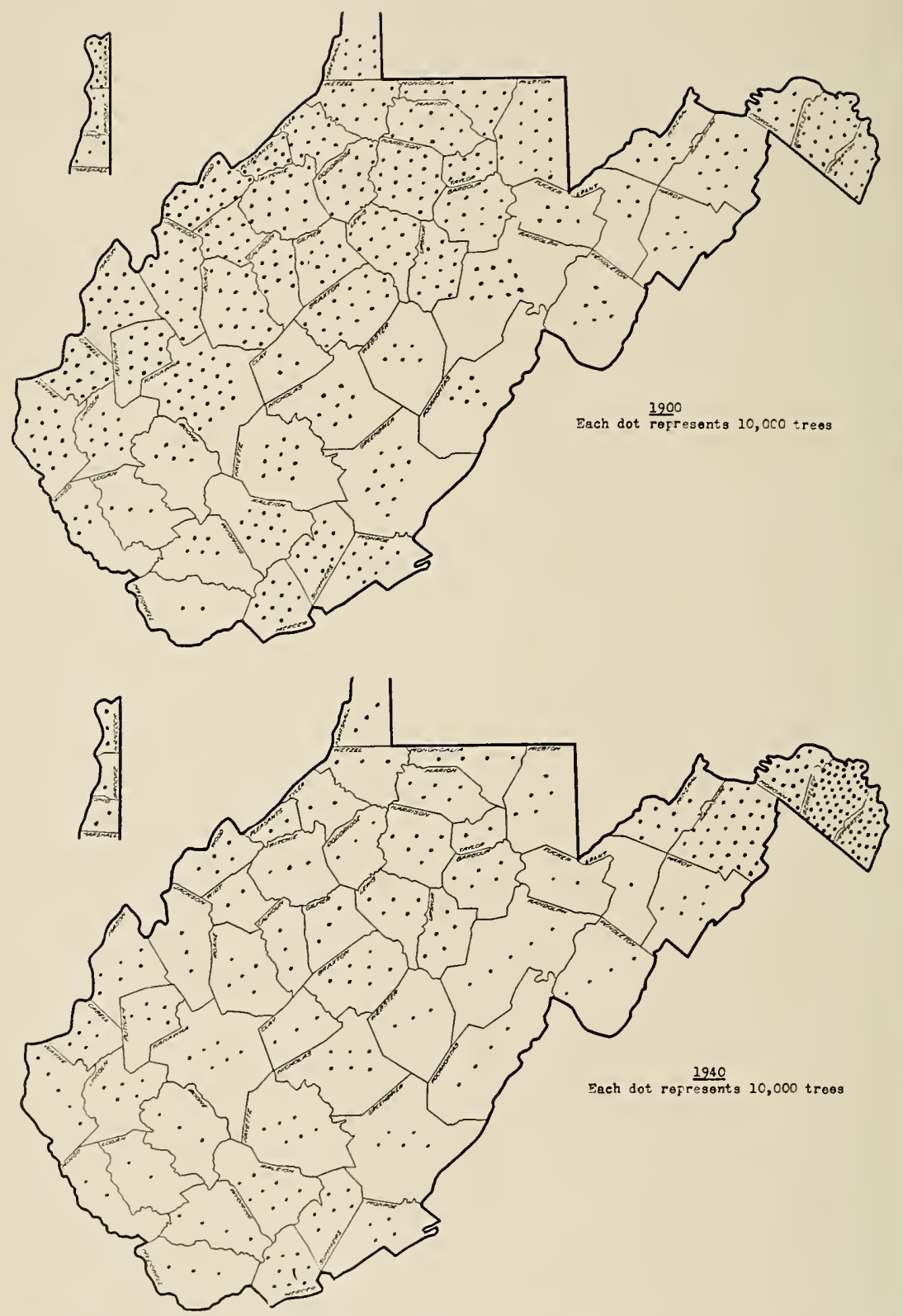

FIG. 1-Number of Trees of Bearing Age Reported by Counties in West Virginia, 1900 and 1940 
During the period 1900-1940, marked changes also have occurred in the number of apple trees reported for West Virginia and in the concentration of trees in various parts of the state. (See Appendix Table C.) Except for some variations as to time, however, many of the same considerations that influcnced apple-tree numbers in other parts of the country, particularly the Eastern area, also were significant in West Virginia. Not only has the total number of trees declined-particularly so since 1930-but also the percentage that trees of nonbearing age are of trees of bearing agc declined significantly until the 1920's. Data presented in Figure 1 show that since 1900 a marked shift in the number of trees in various parts of the state has occurred with considerable concentration of tree numbers in the Eastern Panhandle. (Data showing trends in apple-tree numbers in selected counties and in the Eastern Panhandle for the period 1910-1940 are presented in Appendix Table D.)

Production and Income: Factual information pertaining to apple production in the United States and to various geographic sections is shown in Table $\mathrm{E}$ of the Appendix. Additional information as to the proportion of total gross farm income accounted for by farm income from apples also is given in this table. All data are presented as yearly averages for 5-year intervals beginning in 1910 and continuing through to 1945 . For this period the following trends in production and income seem significant:

(1) Total production of apples has been downward, declining about 25 percent for the period. (Since an appreciable proportion of this decline represents the discontinuance of small farm orchards, it is not evident to what extent there has been an actual reduction in commercial production. In any event the decline in commercial production has been appreciably less than for total production.)

(2) The proportion of apples produced in the Eastern United States has remained reasonably constant, ranging from two-fifths to one-half of total United States production.

(3) The relative importance of apples in the central part of the United States has declined from two-fifths to one-fifth of the total production during the period (38 to 18 percent).

(4) The relative proportion of total production coming from the western part of the United States has shown a marked increase-accounting for 36 percent of all apples grown during the period 1940-1944 as compared with 12 percent for 1910-1914.

(5) The proportion that farm income from apples is of total gross farm income has declined from about 1.7 percent to 1 percent during the past 35 years. While complete information is not available, it appears that during the past decade the income from commercial apples accounted for approximately one-fifth the total income from all fruits.

A rather close relationship exists between production and farm income from apples. The fact that growers in the Eastern area are able to market a considerable proportion of their low-grade fruit to processing plants, while Western producers because of high transportation costs have stressed the production and marketing of high-grade fruit, is a factor that serves to explain why the average price of Western apples is higher than the average price of Eastern apples. The relationship of income to yield in geographic areas for 1943-44 was reported as follows: 
1943-44

Percentage of total

$\begin{array}{cc}\text { Income from } & \text { Apple } \\ \text { apples } & \text { production } \\ \text { percen! } & \text { percent } \\ 41 & 44 \\ 17 & 17 \\ 42 & 39\end{array}$

\section{Competition from Other Fruits}

Of interest and concern to apple growers is their competitive position is compared with other fruits and fruit products. This section gives consideration to trends in the consumption of fresh, canned, juiced, dried, and frozen fruits. ${ }^{9}$ To determine the position of apples as compared with other fruits, it is helpful to give attention to such items as total consumption, per-capita consumption, and percentage of each class accounted for by the more important fruits or fruit products.

Fresh Fruits: The total consumption of fresh fruits has increased ahout 50 percent during the period $1909-1940$. This increase is primarily due to a threefold increase in citrus production. Apples, in contrast, have shown an actual decline; bananas and other fruits have shown some fluctuations but no definite trends. Since 1940, further declines in apple production have been significant. This fact coupled with limitations as to the imports of bananas during the war has resulted in decline in the total consumption of fresh fruit for the war period.

Expressed on a per-capita basis it may be noted that, while no particular trends were discernible for all fruits, per-capita consumption of apples declined one-third from 1909-1940, citrus consumption more than tripled, and bananas - except for the influence of the war-and other fruit remained much the same. The percentage of total consumption accounted for by various kinds of fruit also indicates the extent of changes in the demand for apples and citrus fruits. (For details see Appendix Table F.)

Canned Fruits: While the amount of canned fruit consumed is relatively small when compared with fresh fruit, it is significant that average yearly consumption increased from 34 million pounds for the period 1909-1912 to over two billion pounds for the period 1940-1944, an increase of over 600 percent. This represents a change in average yearly per-capita consumption from 3.4 to 15.3 pounds for the period.

Peaches and pineapples are the most important canned fruits, together accounting for nearly one-half of the total output in this classification. It also is significant that total per-capita consumption of these fruits increased about five and eight times, respectively, between 1909 and 1940, while the per-capita consumption of canned apples and applesauce only doubled. In fact it was as high in 1917-1920 as in 1937-1940. It may be noted that wartime influences on consumption resulted in an increase of canned apples and applesauce and a decrease in canned pineapples. (The relative position of

"Statistical data for this discussion were compiled from "Production and Consumption of Fruits." U.S.D.A.. July 1943, and from supplementary data furnished through the United States Department of Agriculture. 
canned apples and applesauce as compared with other fruits is shown in further detail in Appendix Tablc G.)

Canned Fruit fuices: Although not as important as canned fruits, canned fruit juices have become of increasing significance during the past decade. From a per-capita consumption of 0.3 pounds during 1909-1912, a 37 -fold increase was reported by 1940-1944. Apple juice represented a very insignificant proportion of the canned fruit juices consumed and has cxperienced very strong competition from all other classes of fruit. The facts that apple juice has not built up wide consumer acceptance and has a relatively low vitamin content are considerations that have made it difficult for this product to compete with most other canned fruit juices. During recent years grapefruit and other fruits have become the important items included among canned fruit juices, while pineapple and citrus juices have experienced relative declines. (For details see Appendix Table H.)

Dried Fruits: Since an appreciable proportion of the water is removed in drying fruits, the consumption of fruit in this form would seem to be of more significance than the total poundage consumed indicates. During the period 1909-1940 the volume of fruit dried practically doubled, and per-capita consumption increased about 50 percent, only to decline slightly from 1941 to 1944. Prunes and raisins constituted the chief dried fruits. Apples, apricots, dates, figs, peaches, pears, and currants were of minor importance. It may be noted that, for the period considered, the per-capita consumption of prunes and raisins nearly doubled, for apples it decreased, and the other fruits either showed little change or increased somewhat. Such changes as occurred took place primarily during the first half of the period. Prunes and raisins accounted for two-thirds to three-fourths of the total fruit dried, and apples have been of little significance since 1917-1920. (See Appendix Table I.)

Other Fruits and Vegetables: During recent years freezing of fresh fruits has become increasingly important. The per-capita consumption of freshfrozen fruit increased from 0.2 pounds in 1925 to 1.2 pounds in 1940, a sixfold increase. Strawberries and red sour cherries are the most important freshfrozen fruits. While definite information is not available as to the extent to which fresh and frozen vegetables may compete with apples for a place on the housewife's table, it should not be overlooked that the marketing methods applied to these two fruits have undergone marked improvement, particularly in packaging, and that they too may at times replace apples for many purposes in the human diet.

To summarize, an appraisal of the competitive position of apples indicates that, in respect to other fruits, the industry has lost much ground since 1910. Although no significant trends are to be noted in the total amount of commercial apples offered for sale, per-capita consumption has declined. During the same time, consumption of citrus fruits has shown a marked increase, and no definite trends are to be noted for most of the other important fruits. While the per-capita consumption of all classes of canned fruit has shown a marked increase, it has been less for canned apples than for other fruits. Much the same relationships prevailed for fruit juice. As for dried fruits, increase in per-capita consumption primarily has been accounted for by trends in prunes and raisins. It seems evident that, to counter the trends now prevailing in the apple industry, producers will have to give more attention to the advantages of 
developing a long-time research program dealing with such problems as: (1) variety development, (2) soil and climatic adaptability, (3) management and cultural practices, (4) marketing methods (including packing, packaging materials, storage practices, financing, and sales methods), (5) processing of apple byproducts, and (6) more effective and efficient methods of disease and insect control.

\section{General Economic Considerations}

This section gives brief attention to the importance of two factors that have a marked influence on returns from apple production. These are: (1) consumer purchasing power and (2) foreign trade.

Consumer Purchasing Power: Returns from apples depend to a large extent upon the amount of purchasing power in the hands of consumersparticularly nonfarm persons. The relationship of farm returns from commercial apple production to the average per-capita income of nonfarm persons may be observed by examination of Figure 2. The close relationship that prevails between the price that growers receive for apples and the income of nonfarm persons suggests that apple producers have a definite interest in (a) maintenance of a high level of industrial activity, (b) full employment, and (c) relatively high industrial wages. It is only when such conditions prevail that consumers have the money with which to pay a reasonable price for apples. Since apples are often considered a semi-luxury food by large segments of the population, many consumers tend to rank them high or low in their food preference largely according to their available purchasing power.

Another factor centers about the relationship of consumer income to differences in the quality of apples sold. Irrespective of general economic policies adopted or cultural practices and grading standards inaugurated relative to apples, it seems likely that wide differences in the purchasing power of consumer groups as well as in the quality of apples produced will continue to be common. Furthermore, it should be recognized that any practice which causes the price of apples to increase to the extent that they get beyond the reach of consumers or are relatively higher-priced than other fruits does much to keep such consumers from becoming "apple conscious."

Consumption studies indicate that there are times and conditions when a large portion of the apple crop can be sold most profitably with a minimum of marketing frills. Not only would such a policy tend to reduce marketing costs: it would contribute also to fuller and more effective utilization of resources devoted to apple production. In any event an effective marketing program for apples should seek to bring about full utilization of existing production. The realization of such a goal calls for careful analysis of market possibilities to the end that consumers are most effectively supplied with the quality of apples they desire and can use at a price that reflects their ability to buy.

Foreign Trade in Apples: The disturbing influences of World War II on the export apple business combined with relatively favorable conditions prevailing in home markets during this period may have served to overemphasize the importance of domestic outlets for apples. Foreign outlets should not be deprecated. This is especially true in light of the fact that during the period between World Wars I and II (1919-1938) yearly net exports ranged from 2.8 to 16.5 percent of total production and averaged over 10 percent for 12 years. 


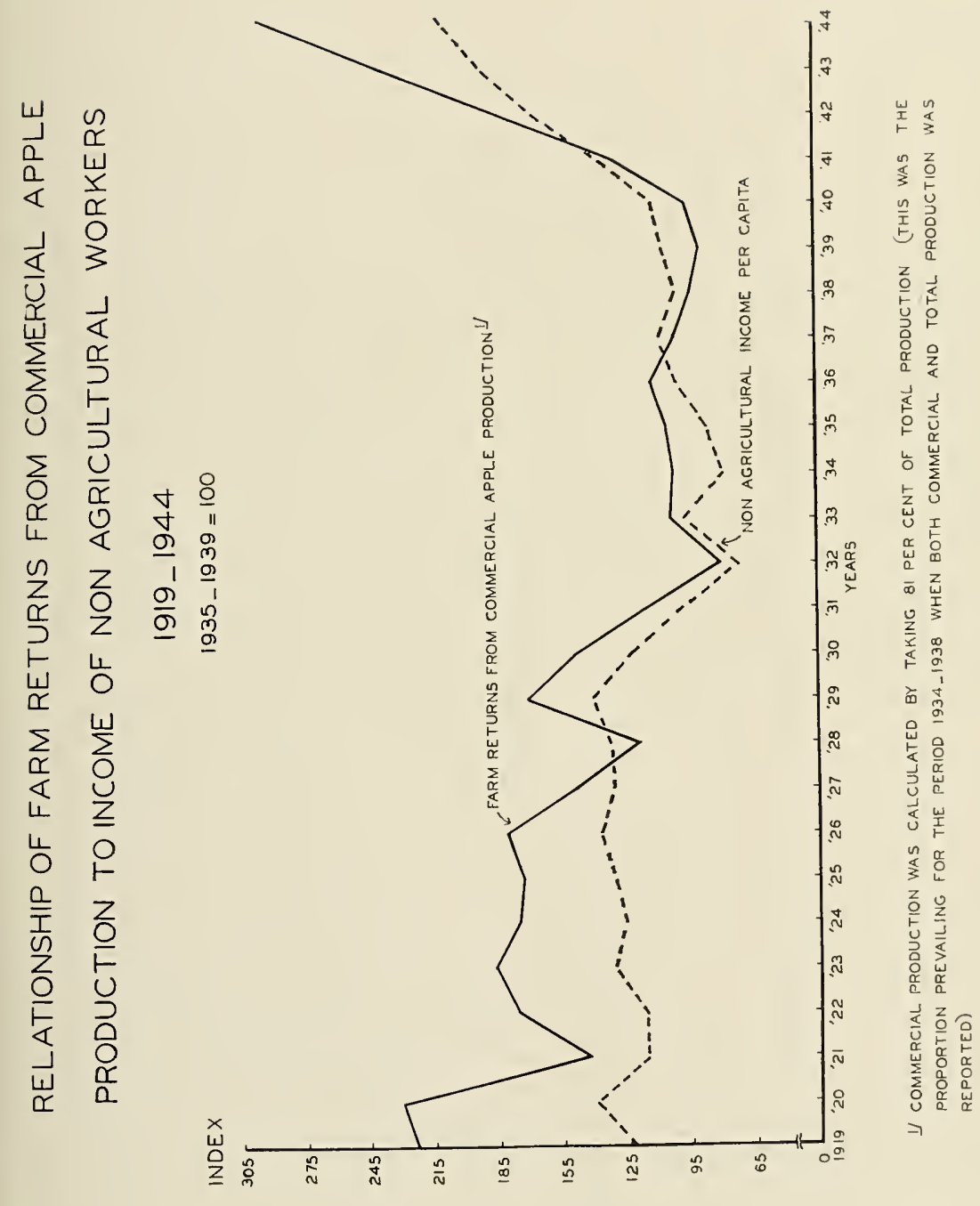

FIGURE 2 
Average net exports for 4-year periods and the percentage that those exports were of total production were as follows:

\begin{tabular}{ccc} 
& \multicolumn{2}{c}{ Total } \\
1,000 & Percentage of \\
Period & bushels & total production \\
$1919-22$ & 6,271 & percent \\
$1923-26$ & 17,850 & 4.0 \\
$1927-30$ & 20,773 & 9.9 \\
$1931-34$ & 18,646 & 14.2 \\
$1935-38$ & 15,500 & 11.9 \\
$1939-42$ & 166 & 10.0 \\
& & 0.1
\end{tabular}

During this same period exports of other fruit have been significant. For instance, pear exports were relatively higher than apple exports, peaches were relatively lower, and orange exports approached those of apples. It also is significant that, while apple exports have been declining since 1930, pears and oranges have shown a rather steady gain in foreign trade.

It admittedly is difficult to appraise accurately the influence of consumer purchasing power and foreign markets on the income of fruit farmers and more particularly the income of apple growers. What is more, unstable world political and economic conditions often add uncertainty to business activities and foreign market outlets. It should be remembered, however, that world markets normally constitute an important part of the demand for American apples. With the rehabilitation of Europe and with prospect for some eventual decline in domestic industrial activity, foreign markets in all likelihood again will merit the careful attention of the apple industry.

\section{COSTS AND RETURNS FROM APPLE PRODUCTION}

This section gives consideration to costs and returns associated with production on bearing apple orchards in the Eastern Panhandle of West Virginia. All costs and returns from general farming operations as well as from such fruits as peaches and cherries have been eliminated. In other words, attention is restricted to the apple enterprise on the farms studied. In many cases actual data were available for this purpose. In others, knowledge of operations and consultation with growers permitted a workable proration of important cost items pertaining to various fruits. On the same basis all costs associated with the development of young (nonbearing) apple orchards were omitted in order to arrive at the most accurate information possible relative to actual costs for producing apples.

Costs and returns reported in this study cover the 4-year period 19381941. Because of inherent characteristics of apple production in West Virginia, it is not unusual to have crops that range from 50 percent below to over 50 percent above normal yields every 3 to 5 years. Therefore the importance of having data covering a period of years to serve as a basis for drawing conclusions is especially evident. Presentation of data for the 4 years selected for this study also has the advantage of allowing for the balancing influence of two "on" and two "off" years of production. This further permits the influence of such factors as weather, disease outbreaks, and insect infestations 
to approach normal - a condition that may not prevail when observations are made for only one year. Information for a 4-year period may also permit such economic factors as price, consumer purchasing power, supply and equipment costs, and trends in foreign trade more effectively to "average out" their influence on apple returns than is possible when considering operations for but one season.

Data presented in Table 4 give characteristics for the 4 -year period 1938-1941. They show that this period from the standpoint of production and income compares reasonably well with the most recent 10 -year period. Rainfall also corresponds very closely with the monthly average for the preceding 10 years. Both production and rainfall, in fact, showed less than usual variation for the period. It is appreciated, of course, that such matters as seasonable distribution of rainfall and prevalence of disease and insect outbreaks are other important considerations. Indications, however, suggest that no unusual situations prevailed in this respect for the period selected for intensive study. Income for 1938-1941 as compared with 1935-1944 is low primarily because of (1) low prices during the first two years selected for study, (2) limited forcign trade in apples during 1938-1941, and (3) unusually high prices for apples after 1941.

TABLE 4-Comparisons for the Period Selected for Study With Averages for 1935-1944, West Virginia and United States

\begin{tabular}{|c|c|c|c|c|c|}
\hline \multirow{2}{*}{$\begin{array}{l}\text { Years and } \\
\text { period }\end{array}$} & \multicolumn{2}{|c|}{$\begin{array}{c}\text { Commercial } \\
\text { apple production }\end{array}$} & \multicolumn{2}{|c|}{$\begin{array}{l}\text { Cash income from } \\
\text { commercial production }\end{array}$} & \multirow{2}{*}{ Rainfall ${ }^{1}$} \\
\hline & $\begin{array}{c}\text { West } \\
\text { Virginia }\end{array}$ & $\begin{array}{l}\text { United } \\
\text { States }\end{array}$ & $\begin{array}{c}\text { West } \\
\text { Virginia }\end{array}$ & $\begin{array}{l}\text { United } \\
\text { States }\end{array}$ & \\
\hline $\begin{array}{l}1938 \\
1939 \\
1940 \\
1941\end{array}$ & $\begin{array}{c}1,000 \\
\text { bushels } \\
3,774 \\
4,369 \\
4,420 \\
4,288\end{array}$ & $\begin{array}{c}1,000 \\
\text { bushels } \\
105,718 \\
139,247 \\
111,439 \\
122,585\end{array}$ & $\begin{array}{c}, 000 \\
\text { dollars } \\
3,190 \\
3,036 \\
3,348 \\
4,165\end{array}$ & $\begin{array}{r}1,000 \\
\text { dollars } \\
83,851 \\
80,113 \\
85,283 \\
115,051\end{array}$ & $\begin{array}{c}\text { inches per } \\
\text { month } \\
2.66 \\
3.27 \\
3.70 \\
2.42\end{array}$ \\
\hline Av. $1938-41$ & 4,213 & 119,747 & 3,435 & 91,075 & 3.01 \\
\hline Av. $1935-44$ & 4,154 & 119,953 & 3,715 & 127,384 & 3.19 \\
\hline
\end{tabular}

'At the University Experiment Farm, Kearneysville, W. Va. Averages are for 1934-1943.

\section{Characteristics of the Apple Orchards Studied}

A previous study has indicated three types of apple-orchard operations in West Virginia ("orchard," "orchard-general," and "general-orchard"). $1 "$ The present study, however, was restricted primarily to "orchard" operations and to the apple enterprise on these farms. This is by far the most important of the three classes of apple producers referred to. Besides, a high proportion of nonbearing trees on "orchard-gencral" farms indicates a trend on these farms toward full-scale commercial production. In contrast, the fact that the "general-orchard" farms have a very limitcd number of nonbearing trees serves to suggest that these particular farms will not be an especially significant factor in the apple business during the years ahead. While these trends indicate a concentration of apple production on the larger farms, they should not be

\footnotetext{
"'M. A. Abrahamsen, 4 Labor Lncome Study of Orchard Furms in The Eastern I'anhandle of Hest Virginiu. W. Va. Agr. Expt. Sta. Mim. Cir. No. 27. Jan. 1938. This cireular deseribes these elasses of orchard operations as follows: "Orchard farms are large-scale holdings generally operated on a corporation basis. Orchard-general farms normally obtain one-half or more of all receipts from fruit production while general-orchard farms normally obtain less than one-half of all income from fruit."
} 
interpreted as indicating that other types of orchard operations will cease to exist. Often commercial apple orchards, as ownership shifts and as interest in orchard maintenance lags, pass through the "general-orchard" classification as blocks of trees are removed and as the operation gradually reverts to general farm operations. In contrast, as new orchards are developed, many are on holdings where considerable farming is conducted.

On the particular orchards selected for intensive study the following characteristics will help describe the nature of current apple-production operations: (1) average size of holdings in bearing apples, 91.6 acres; (2) average yearly yield, 257 bushels per acre; and (3) proportion of fruit packed, 57 percent. Another factor of considerable importance is the fact that somewhere around two-thirds of the orchards (about one-half of the acreage) operated in the Eastern Panhandle are leased or rented orchards. Some of the larger operators have a dozen or more separate holdings under their control. In some instances only the orchard holdings are leased, and owners operate the remaining farm enterprises. In other instances operators have moved from the community, and a sizeable group of absentee owners has come into being.

\section{Costs, Returns, and Investments ${ }^{11}$}

Data presented in Table 5 indicate that for the 4-year-period 1938-1941 the average apple enterprise reported yearly gross returns of $\$ 17,175$, expenses of $\$ 16,384$, net returns of $\$ 791$, and a total investment of $\$ 20,982$. It may be noted that production items accounted for approximately one-fifth of total costs; harvesting for one-third; marketing for nearly one-fifth; and overhead for one-fourth. Expressed on a per-acre, per-tree, and per-bushel basis, total costs were, respectively, $\$ 179, \$ 4.02$, and 69 cents. Correspondingly, net returns were $\$ 9.00$ per acre, 19 cents per tree, and 3 cents per bushel.

About one-third of total investments was accounted for by land in bearing trees, between one-third and two-fifths by estimated costs of developing bearing orchards, one-fifth by buildings, and one-seventh by equipment (primarily spraying equipment, trucks, and tractors). Expressed on a unit basis, these items were as follows: per acre, $\$ 229$; per tree, $\$ 5.15$; and per bushel, 88 cents. For the same period profits (net returns) averaged 3.8 percent on total investments. Detailed consideration is given to various types of costs in the succeeding sections.

Production costs: Production items comprised 20 percent of all costs related to apple production and averaged $\$ 3,334$ dollars per farm. These items were about evenly divided between labor and materials. On a unit basis they were as follows: per acre, $\$ 36.41$; per tree, 82 cents; and per bushel, 14 cents (Table 6).

Further consideration of these items indicates that from the standpoint of labor, pruning accounted for one-fourth the total labor expense, spraying for between one-third and two-fifths, cultivating for about one-tenth, and thinning for another one-tenth. Spraying material accounted for around seven-tenths of the cost of all materials and, when combined with fertilizer and gas and oil, comprised the major material costs.

${ }^{11}$ For a general summary of costs and returns by individual years see Appendix Table J. 
TABLE 5-Summary of Orchard Organization as Reported for the 4-year Period 1938-1941 for 45 Apple Orchards in the Eastern Panhandle of West Virginia ${ }^{1}$

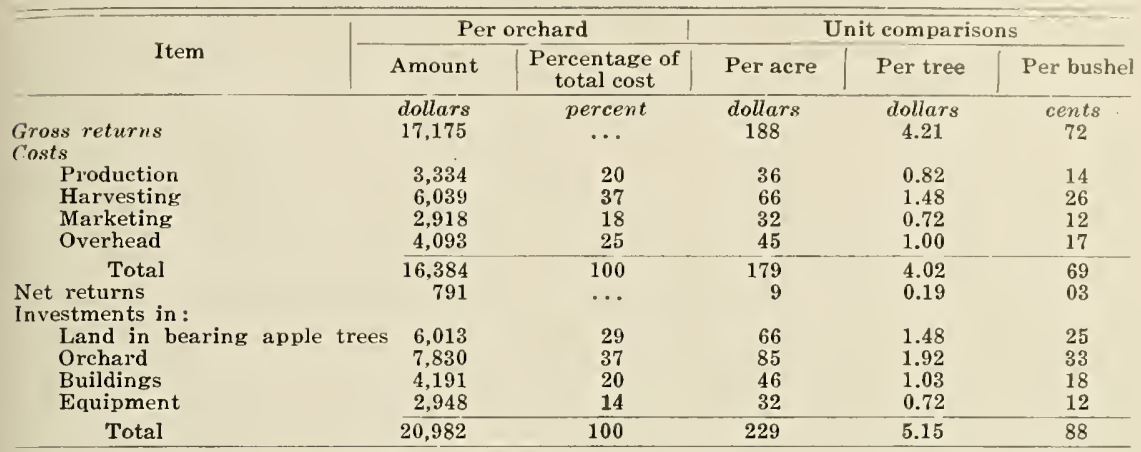

IIn this and subsequent tables, unless otherwise indicated, all averages are weighted averages. In other words per-acre, per-tree, and per-bushel averages are based on the respective units of each that various operators contributed to the total.

Since relatively low apple prices prevailed during the period studied, there was a natural tendency to hold expenses to a minimum. This is understandable when it is realized that 23 of the 45 orchards studied reported operating losses for the period. Under these conditions many growers cut corners on such production items as pruning, fertilizing and spraying. This situation undoubtedly was a factor in contributing to lower-than-average production costs for the period under study.

In spite of these conditions, however, it should be noted that most production costs, with the possible exception of thinning and propping, are relatively fixed items when expressed on a per-acre basis. It is only in instances of almost complete crop failure (when some operators pull small numbers of green

TABLE 6-Yearly Average Production Costs as Reported for the 4-year Period 1938-1941 for 45 Apple Orchards in the Eastern Panhandle of West Virginia

\begin{tabular}{|c|c|c|c|c|c|c|}
\hline \multirow[b]{2}{*}{ Item } & \multicolumn{3}{|c|}{ Per orchard } & \multicolumn{3}{|c|}{ Unit costs } \\
\hline & Amount & $\begin{array}{l}\text { Per } \\
\text { total }\end{array}$ & $\begin{array}{l}\text { age of: } \\
\text { class }\end{array}$ & Per acre & Per tree & Per bushel \\
\hline Labor I & dollars & percent & percent & dollars & dollars & cents \\
\hline Pruning & 423 & 12.7 & 27.2 & 4.61 & 0.10 & 1.8 \\
\hline Fertilizing & 36 & 1.1 & 2.3 & 0.40 & 0.01 & 0.2 \\
\hline Cultivating & 155 & 4.7 & 10.0 & 1.69 & 0.04 & 0.6 \\
\hline Spraying & 557 & 16.7 & 35.9 & 6.08 & 0.14 & 2.3 \\
\hline Thinning & 167 & 5.0 & 10.8 & 1.84 & 0.04 & 0.7 \\
\hline Propping & 38 & 1.1 & 2.4 & 0.41 & 0.01 & 0.2 \\
\hline Unclassified & 177 & 5.3 & 11.4 & 1.93 & 0.04 & 0.7 \\
\hline Material Total & 1,553 & 46.6 & 100.0 & 16.96 & 0.38 & 6.5 \\
\hline Fertilizer & 255 & 7.7 & 15.6 & 2.79 & 0.06 & 1.1 \\
\hline Seed & 50 & 1.5 & 3.1 & 0.54 & 0.01 & 0.2 \\
\hline Spraying & 1,136 & 34.1 & 69.4 & 12.41 & 0.28 & 4.8 \\
\hline Gas and oil & 178 & 5.3 & 10.9 & 1.94 & 0.04 & 0.7 \\
\hline Unclassified & 17 & 0.5 & 1.0 & 0.19 & 0.01 & 0.1 \\
\hline $\begin{array}{l}\text { Total } \\
\text { Unclassified }\end{array}$ & $\begin{array}{r}1,636 \\
145\end{array}$ & $\begin{array}{r}49.1 \\
4.3\end{array}$ & $\begin{array}{c}100.0 \\
\ldots\end{array}$ & $\begin{array}{r}17.87 \\
1.58\end{array}$ & $\begin{array}{l}0.40 \\
0.04\end{array}$ & $\begin{array}{l}6.9 \\
0.6\end{array}$ \\
\hline Total all productior & 3,334 & 100.0 & $\ldots$ & 36.41 & 0.82 & 14.0 \\
\hline
\end{tabular}

'See Appendix Table $\mathbf{K}$ for seasonal distribution of production labor and for the average hours reported per 100 acres of each operation. 
apples from the trees) that growers may be justified in omitting most spraying operations. Production costs primarily are undertaken in expectation of crop returns before many of the factors affecting yields have made their influence felt. It is evident, of course, that various factors beyond control of the grower maty greatly modify production before harvest.

Harvesting Costs: In contrast with production costs, harvesting expenses usually are in direct proportion to the amount of fruit produced and packed. Except for the influence of such factors as high per-bushel picking costs on orchards with low production, decreased efficiency in the operation of packing sheds under such conditions, and the packing of only a small proportion of the fruit produced, harvesting costs are in direct relation to production costs.

Harvesting costs averaged \$6,039, or nearly twice as much as production costs. Picking and packing, the principal labor items, were of about equal significance; each accounted for between one-fifth and one-fourth of total harvesting costs. Together they were about equal to the cost of packing material. Hauling was the only other item of major significance. It should be mentioned that for cull fruit, however, a considerable share of hauling costs has been assumed by purchasers and thus does not appear as regular expense items. Expressed on a unit-cost basis, harvesting costs were as follows: per acre, \$65.96; per tree, \$1.48; and per bushel, 25.3 cents (Table 7 ).

TABLE 7-Yearly Average Harvesting Costs as Reported for the 4-year Period 1938-1941 for 45 Apple Orchards in the Eastern Paninandle of West Virginia

\begin{tabular}{|c|c|c|c|c|c|}
\hline \multirow{2}{*}{ Item } & \multicolumn{2}{|c|}{ Per orchard } & \multicolumn{3}{|c|}{ Unit costs } \\
\hline & Amount & $\begin{array}{c}\text { Percentage } \\
\text { of total }\end{array}$ & Per acre & Per tree & Pex bushel \\
\hline Labor $r^{1}$ & dollars & percent & dollars & dollars & cents \\
\hline Picking & 1,226 & 20.3 & 13.39 & 0.30 & 5.1 \\
\hline Packing? & 1,405 & 23.3 & 15.35 & 0.35 & 5.9 \\
\hline Hauling & 527 & 8.7 & 5.75 & 0.13 & 2.7 \\
\hline Packing material & 2,622 & 43.4 & 28.64 & 0.64 & 11.0 \\
\hline Unclassified & 259 & 4.3 & 2.83 & 0.06 & 0.6 \\
\hline Total & 6.039 & 100.0 & 65.96 & 1.48 & 25.3 \\
\hline
\end{tabular}

ISee Appendix Table $K$ for the seasonal distribution of labor for harvesting items and for the average hours reported per 100 acres of each operation.

2 Attention is called to the fact that packing costs are expressed on the basis of the entire production and not on the basis of fruit packed. Since 57 percent of the fruit sold was packed, packing-labor costs and packing-material costs, respectively, would be 10.4 and 19.3 cents per bushel packed.

Marketing Costs: Not unlike harvesting costs, expenditures for marketing as a rule are in direct proportion to the number of bushels of apples produced. They averaged $\$ 2,918$ per farm for the apple enterprise-a figure approximating one-half that of harvesting costs. Three items (storage, commissions, and freight and trucking) each accounted for between one-fourth and one-third of total marketing costs. Expressed on a per-unit basis, total marketing costs were as follows: per acre, $\$ 31.87$; per tree, 72 cents; and per bushel, 12.2 cents (Table 8).

Overhead Costs: Overhead represents a cost item that frequently is not given full recognition by apple producers. This is because many of the items in this classification do not represent direct cash (out of pocket) expenditures. It also is due in part to very real difficulties in placing equitable values on some of the overhead items. The more important of these include interest on investment in land; interest on bearing trees; depreciation of mature trees; 
TABLE 8-Yearly Average Marketing Costs as Reported for the 4-year Period 1938-1941 for Selected Apple Orchards in the Eastern Panhandle of West Virginia

\begin{tabular}{l|r|r|rrr|r}
\hline \multirow{2}{*}{ Item } & \multicolumn{2}{c}{ Per orchard } & \multicolumn{3}{c}{ Unit costs } \\
\cline { 2 - 5 } & A mount & $\begin{array}{c}\text { Percentage } \\
\text { of total }\end{array}$ & Per acre & Per tree & Per bushel \\
\cline { 2 - 6 } & & dollars & percent & dollars & dollars & cents \\
Storage & 870 & 29.8 & 9.51 & 0.21 & 3.6 \\
Commission & 1,005 & 34.5 & 10.98 & 0.25 & 4.2 \\
Freight and trucking & 830 & 28.4 & 9.06 & 0.20 & 3.5 \\
lnspection and advertising & 143 & 4.9 & 1.56 & 0.04 & 0.6 \\
Unclassified & 70 & 2.4 & 0.76 & 0.02 & 0.3 \\
$\quad$ Total & 2,918 & $\mathbf{1 0 0 . 0}$ & 31.87 & 0.72 & 12.2 \\
\hline
\end{tabular}

${ }^{1}$ Because many growers sold all or part of their fruit on net basis (less marketing costs), data used in this table are derived from information furnished by growers having actual marketing costs. The number varied from 15 to 19 per year.

depreciation and repairs on buildings and equipment; and such additional items as administration, interest on the average amount of working capital used, insurance, taxes, and other minor expenses. ${ }^{12}$

It may be noted that average yearly overhead costs were $\$ 4,093$ for the orchards studied. This was equivalent to $\$ 44.70$ per acre, $\$ 1.00$ per tree, and 17.2 cents per bushel (Table 9 ). Total overhead costs amounted to 25 percent of all orchard costs.

Adequate information was not available for placing a value on the bare land used for orchards. Experience has demonstrated, however, that the value placed on land by operators often was more likely to be the result of managerial ability or was influenced by sentimental attachments rather than by the

TABLE 9-Summary of Average Annual Orchard Overhead Costs as Reported for the 4-year Period 1938-1941 for 45 Apple Orchards in the Eastern

Panhandle of West Virginia

\begin{tabular}{|c|c|c|c|c|c|}
\hline \multirow[b]{2}{*}{ Item } & \multicolumn{2}{|c|}{ Per orchard } & \multicolumn{3}{|c|}{ Per-unit costs } \\
\hline & Amount & $\begin{array}{l}\text { Percentage } \\
\text { of total }\end{array}$ & Per acre & Per tree & Per bushel \\
\hline & dollars & percent & dollars & dollars & cents \\
\hline $\begin{array}{l}\text { Land } \\
\text { Interest on inv. (5\%) } \\
\text { Bearing orchard }\end{array}$ & 300 & 7.3 & 3.28 & 0.07 & 1.3 \\
\hline $\begin{array}{l}\text { Interest on inv. (5\%) } \\
\text { Depreciation }\end{array}$ & $\begin{array}{l}391 \\
621\end{array}$ & $\begin{array}{r}9.6 \\
15.2\end{array}$ & $\begin{array}{l}4.27 \\
6.78\end{array}$ & $\begin{array}{l}0.10 \\
0.15\end{array}$ & $\begin{array}{l}1.6 \\
2.6\end{array}$ \\
\hline Buildings & 1,012 & 24.8 & 11.05 & 0.25 & 4.2 \\
\hline $\begin{array}{l}\text { Interest on inv. (5\%) } \\
\text { Depreciation } \\
\text { Repairs }\end{array}$ & $\begin{array}{r}210 \\
128 \\
48\end{array}$ & $\begin{array}{l}5.1 \\
3.1 \\
1.2\end{array}$ & $\begin{array}{l}2.29 \\
1.40 \\
0.53\end{array}$ & $\begin{array}{l}0.05 \\
0.03 \\
0.01\end{array}$ & $\begin{array}{l}0.9 \\
0.5 \\
0.2\end{array}$ \\
\hline $\begin{array}{c}\text { Total } \\
\text { Equipment }\end{array}$ & 386 & 9.4 & 4.22 & 0.09 & 1.6 \\
\hline $\begin{array}{l}\text { Interest on inv. (5\%) } \\
\text { Depreciation } \\
\text { Repairs }\end{array}$ & $\begin{array}{l}148 \\
252 \\
124\end{array}$ & $\begin{array}{l}3.6 \\
6.2 \\
3.0\end{array}$ & $\begin{array}{l}1.61 \\
2.75 \\
1.36\end{array}$ & $\begin{array}{l}0.04 \\
0.06 \\
0.03\end{array}$ & $\begin{array}{l}0.6 \\
1.1 \\
0.5\end{array}$ \\
\hline Total & 524 & 12.8 & 5.72 & 0.13 & 2.2 \\
\hline $\begin{array}{l}\text { Administration } \\
\text { Capital employed } \\
\text { Insurance } \\
\text { Taxes } \\
\text { Other }\end{array}$ & $\begin{array}{r}1,029 \\
280 \\
123 \\
106 \\
332\end{array}$ & $\begin{array}{r}25.2 \\
6.8 \\
3.0 \\
2.6 \\
8.1\end{array}$ & $\begin{array}{r}11.24 \\
3.06 \\
1.34 \\
1.16 \\
3.63\end{array}$ & $\begin{array}{l}0.25 \\
0.07 \\
0.03 \\
0.03 \\
0.08\end{array}$ & $\begin{array}{l}4.3 \\
1.2 \\
0.5 \\
0.5 \\
1.4\end{array}$ \\
\hline Total & 1,870 & 45.7 & 20.43 & 0.46 & 7.9 \\
\hline Total overhead & 4,092 & 100.0 & 44.70 & 1.00 & 17.2 \\
\hline
\end{tabular}

${ }^{12}$ To place orchards on a more comparable basis, prevailing interest charges were omitted, and irrespective of whether orchards were owned or jented, interest on total investment was charged at the rate of 5 percent. When orchards were rented, rent was omitted as a cost, but taxes, interest on investment, and orchard depreciation were charged. 
inherent productive value of the land. The services of the Land Appraisal Division of the Farm Credit Administration, however, were of assistance in this problem. Consideration on their part of such factors as slope, erosion, and series of soil helped to furnish a basis for appraising land values. On the basis of findings, shale soil was valued at $\$ 35$ to $\$ 50$ per acre; limestone soils were valued at $\$ 50$ to $\$ 75$ dollars per acre.

Orchard depreciation, based on costs associated with developing a growing orchard, also presented a perplexing problem. This was especially true since no adequate data were available for the period when orchards included in this study were growing up. Studies of costs involved in developing a producing orchard indicate that a conservative figure for these costs as they are recognized by the Bureau of Internal Revenue at the time those orchards selected for study were in the nonbearing stage would be around $\$ 150$ per acre. In actual practice no doubt many development costs exceeded this figure. Since, in this study, all apple-orchard development costs were excluded from current operations, it is desirable to make a charge to cover orchard depreciation. Orchards were depreciated in accordance with the formula developed for the "production unit" method of distribution. ${ }^{13}$ Interest on investment in the orchard was charged on the basis of the undepreciated value at the time this study was conducted. It may be noted that interest on investment in and depreciation of bearing apple trees amounted to $\$ 1,012$ per orchard or 24.8 percent of all overhead costs.

Interest on investment, depreciation, and repairs accounted for the building and equipment charges listed in this study as overhead. Strictly speaking, it would have been desirable to allocate these costs among various production, harvesting, and marketing items. Limitations as to the character of the data available, the joint nature of many of these items, and the difficulty of prorating them all were factors, however, that prompted handling these items in overhead. In all instances interest on investment was charged at the rate of 5 percent.

Depreciation on buildings was at the rate of 2 percent for stone, brick, cement, and similar buildings and 3 percent for frame buildings. Depreciation on equipment was at the flat rate of 10 percent. While this was somewhat low for automotive equipment, it was more than enough for many other types of equipment. Indications are that, all kinds of equipment considered, 10 percent represented a fair approximation of these costs.

On a per-farm basis, building overhead was $\$ 386$ and equipment overhead was $\$ 524$ per year. These items represented, respectively, 9.4 percent and 12.8 percent of all overhead costs (Table 9 ). Although many operators had homes valued at considerably over $\$ 5,000$, for the sake of avoiding unjust charges to orchard operations for these growers the practice was adopted limiting valuations on growers' living quarters to a maximum of $\$ 5,000$ for purposes of this study.

Administration and interest charges for working capital represented the principal additional overhead costs, being 25.2 percent and 6.8 percent, respectively, of total overhead costs. No completely satisfactory policy could be established for making charges for administration. Some of the larger

${ }^{13}$ For a discussion of costs of developing an apple orchard and for consideration of features of the "production unit" method of depreciation see pp. 54 to 63. 
corporation orchards paid salaries comparable with well-established industrial firms. Other growers, particularly those operating their own orchards, reported no charge for this important function. In other instances the problem was complicated by such differences as absentee administration, which makes little or no contribution to effective management, and operators whose careful consideration of management responsibilities has resulted in greatly improving the performance of orchards. In order to put orchards on a more equitable basis with respect to administration costs, it was decided to make a flat charge of $\$ 10$ per acre to cover actual administration. Other costs associated with administration, though minor, of ten included gasoline, telephone and other utilities, and similar items.

Neither did it seem equitable to charge interest on working capital on the basis reported by growers. To do so would penalize orchards with interest charges that reflect the financial status of the orchard rather than inherent differences in operation. Therefore interest on working capital (determined as one-half of yearly operating expenditures) was charged at the rate of 5 percent. Since such capital funds, if possessed by growers, would earn an interest charge if put to other uses, it seemed reasonable that a charge should be made for all funds used in current operations, irrespective of whether growers were forced to obtain loans to cover these charges or were using their own accumulated funds for this purpose. (Detailed overhead costs are presented in Table 9.)

\section{Fixed and Variable Costs}

The nature of the costs involved in apple production has a significant bearing on ways in which growers may operate. Reference has already been made to variable costs. Fixed costs, when considered on a per-acre basis, are those that tend to go on or have already been carried out whether production is one-half or twice normal. They include such items as labor, equipment, and material costs for pruning, fertilizer, cultivating, and spraying; and taxes, insurance, depreciation, interest on investment, and administration charges. Variable costs per acre, in contrast, include those that are more or less in direct proportion to production; labor for picking and packing, packing material, and the various expenses associated with marketing are among the most important of these items. When expenses are expressed on a per-bushel basis, however, those items that are variable on a per-acre basis tend to become fixed. Similarly, those that are fixed on an acre basis become variable and tend to change in direct relation to the amount of fruit that is produced.

Data presented in Table 10 indicate the relationship between fixed and variable costs. On a per-acre basis it may be noted that so-called "fixed costs" fluctuate about one-half as much as do variable costs. The higher fixed costs per acre on those orchards having high production seem to indicate that on the more profitable operations growers are in position to give necessary attention to various production items. On the less profitable, low-producing orchards there are indications that some of these items are being neglected. On a perbushel basis it seems that yield per acre has relatively little influence on fixed costs, although variable costs are over twice as high on orchards having a yield of less than 200 bushels per acre as on those having a yield of 300 bushel. or more per acre. 
TABLE 10-Relationship of Fixed and Variable Costs as Reported for 45 Orchards in the Eastern Panhandle of West Virginia, Classified

According to Production, 1938-1941

\begin{tabular}{|c|c|c|c|c|}
\hline \multirow[b]{2}{*}{ Type of comparison } & \multirow{2}{*}{$\begin{array}{c}\text { All } \\
\text { orchards }\end{array}$} & \multicolumn{3}{|c|}{ Yield per acre } \\
\hline & & $\begin{array}{l}\text { Less than } \\
200 \text { bushels }\end{array}$ & $\begin{array}{c}200 \text { to } 300 \\
\text { bushels }\end{array}$ & $\begin{array}{l}\text { Over } 300 \\
\text { bushels }\end{array}$ \\
\hline Per-acre costs & dollars & dollars & dollars & dollars \\
\hline $\begin{array}{l}\text { Fixed } \\
\text { Variable }\end{array}$ & $\begin{array}{r}75 \\
104\end{array}$ & $\begin{array}{l}55 \\
52\end{array}$ & $\begin{array}{l}70 \\
86\end{array}$ & $\begin{array}{r}97 \\
169\end{array}$ \\
\hline Total costs & 179 & 107 & 156 & 266 \\
\hline $\begin{array}{c}\text { Per-bushel costs } \\
\text { Variable }^{1} \\
\text { Fixed }^{1}\end{array}$ & $\begin{array}{l}29 \\
40\end{array}$ & $\begin{array}{l}49 \\
47\end{array}$ & $\begin{array}{l}30 \\
38\end{array}$ & $\begin{array}{l}23 \\
39\end{array}$ \\
\hline Total costs & 69 & 96 & 68 & 62 \\
\hline
\end{tabular}

${ }^{1}$ Fixed per-acre costs become variable per-bushel costs; variable per-acre costs become fixed perbushel costs.

Many elements of flexibility are capable of making their influence felt in both fixed and variable costs. In addition to the influence of such factors as soil series and soil condition, differences in fixed costs among growers, classified according to production per acre, may be explained in such items as amount of pruning done, cultural practices undertaken, and spray programs followed. The experience of many growers during wartime emergencies has indicated that the number of practices normally considered as "must" operations, which growers need to carry out, may be somewhat curtailed, at least for a limited period, without irreparable damage to future production. Similarly, even greater opportunities exist for flexibility in variable cost items. For instance, more research is needed in the development of containers and on the influence of various packing methods on returns. Likewise it is important for growers to realize that, under normal conditions, it is only when a quality package can be produced that they are justified in devoting considerable attention to developing outlets for quality fruit. On the other hand, experience has shown that, for growers to obtain quality products, their problem may be more a matter of timing as to certain cultural practices and maintenance of adequate managerial control, than the inauguration of practices calling for expenditure of large sums of additional money. ${ }^{14}$

The relationship of fixed to total costs, according to yield per acre, was reported as follows:

Yield per acre

bushels

Less than 200

200-300

Over 300

All orchards
Fixed costs as a percentage of total costs

percent

51.4

44.9

36.5

41.9

In general it may be said that, once a grower has committed himself to certain production, harvesting, and marketing practices, many costs become relatively fixed, except for the influence of increased yield on production costs.

1:'The recognized importance of proper timing of cultural practices has caused groups of growers in some states to consider plans for employment of management experts to advise on problems of conducting and timing various cultural practices. 


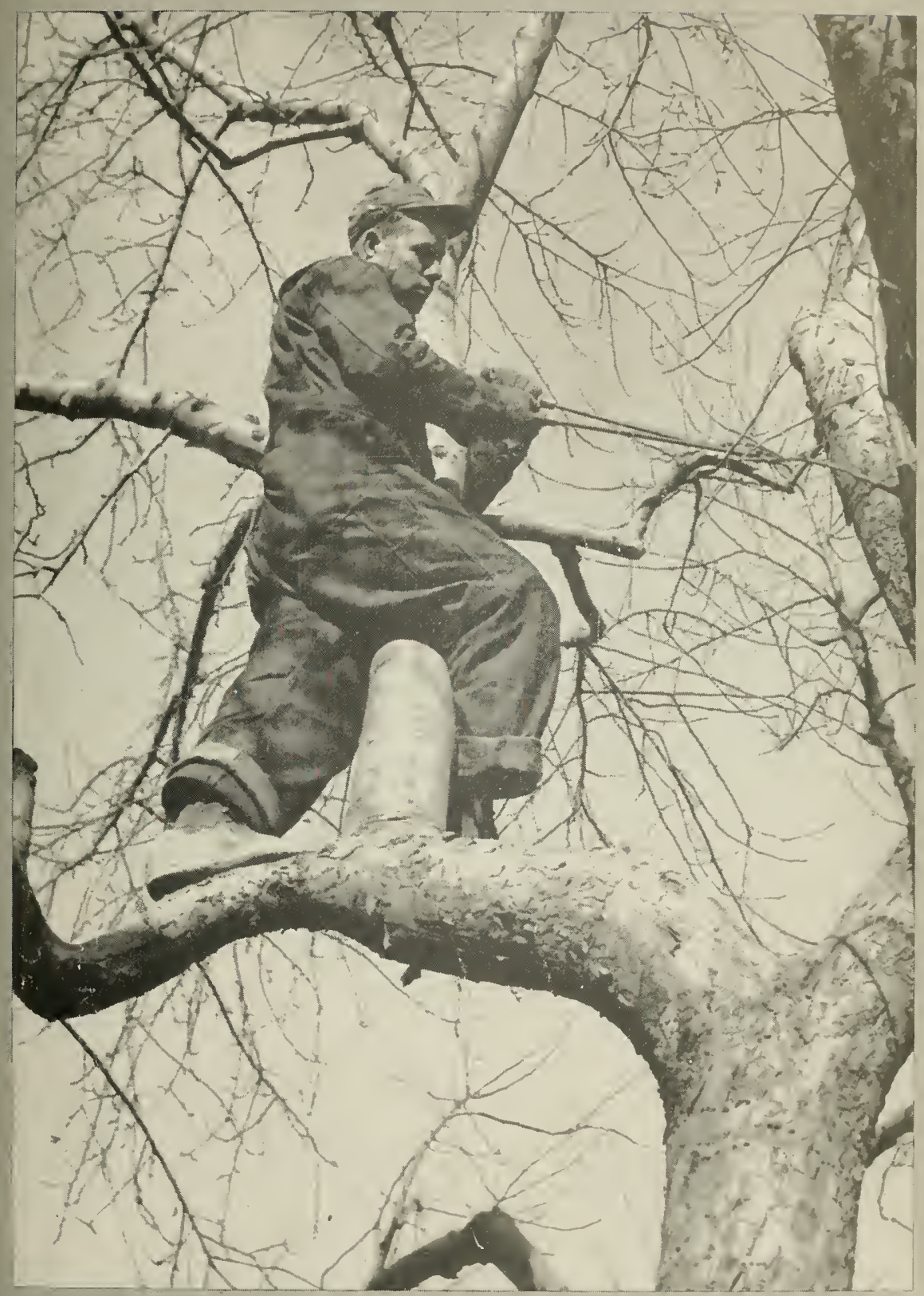


High yield per acre is the principal means of reducing variable per-bushel costs. In other words, such items as pruning, spraying, cultural practices, taxes, insurance, depreciation, and administration, within limits are much the same whether yields are high or low. Therefore, as high yields reduce these costs on a per-bushel basis, the contributions of management to profitable opcration become more evident. Data in Table 10, for instance, show that variable costs were but 23 cents per bushel when average yields were over 300 bushels per acre, as compared with 49 cents per bushel when yields were less than 200 bushels per acre. This suggests that the factors that contribute to increased yields are particularly important in determining the costs of producing fruit and consequently the financial status of most orchards.

\section{Cash and Noncash Costs}

Previous discussion of overhead expense has indicated that some of the costs associated with orchard operation are not cash items. Foremost of these are depreciation, interest on investment, and unpaid family labor and supervision. While it is possible to operate apple orchards for a considerable period of time as long as only cash expenses are met (or for even a longer period of time when commercial or other agencies are willing to extend credit), the fact nevertheless remains that, if apple orchards do not meet depreciation as well as cash expenses, sooner or later operators will be forced to "sit down to a banquet of consequences."

Data obtained in this study indicate that noncash costs amounted to 14 percent of total costs, ranging from a high of 18 percent on orchards yielding less than 200 bushels per acre to a low of 12 percent on orchards yielding over 300 bushels per acre. The proportion of total expenses classified as cash and noncash for orchards grouped according to yields per acre was reported as follows:

\begin{tabular}{|c|c|c|c|}
\hline \multirow{3}{*}{$\begin{array}{c}\text { Yield per acre } \\
\text { bushels }\end{array}$} & \multicolumn{3}{|c|}{ Expenses } \\
\hline & \multicolumn{2}{|c|}{ Per bushel: } & Percentage of \\
\hline & cash & non-cash & $\begin{array}{l}\text { total that is } \\
\text { non-cash }\end{array}$ \\
\hline & cents & cents & percent \\
\hline Under 200 & 78 & 18 & 18 \\
\hline $200-300$ & 57 & 11 & 16 \\
\hline Over 300 & 55 & 7 & 12 \\
\hline All orchards & 59 & $\overline{10}$ & 14 \\
\hline
\end{tabular}

Inability to meet cash expenses means that growers will encounter one or more of the following difficulties: (1) a very low standard of living for the operators and their families, (2) inability to replace or maintain the bearing orchard with consequent dissipation of orchard investment, and (3) inability to realize any returns on the money currently invested in orchards.

\section{SIGNIFICANT FEATURES OF SELECTED ORCHARDS}

This section gives consideration to: (1) comparison of the 10 most profitable and the 10 least profitable orchards studied and (2) description of significant features of five selected orchards--three in the most profitable class and two in the least profitable class. The more important compari- 
sons receiving attention include yield per acre; percentagc of fruit packed; series of soil; age of trees; varieties grown; investments in land, orchard, equipment, and buildings; and costs and returns expressed on both a per-acre and a per-bushel basis.

\section{Most Profitable and Least Profitable Orchards}

Comparison of the 10 most profitable and the 10 least profitable orchards studied brings to the foreground some of the more important characteristics that serve to distinguish these two classes of orchards.

TABLE 11-Summary Comparisons for 10 Most Profitable and 10 Least Profitable Apple Orchards in the Eastern Panhandle of West Virginia, 1938-1941

\begin{tabular}{|c|c|c|c|}
\hline Item & $\begin{array}{c}\text { Average } \\
45 \\
\text { orchards }\end{array}$ & $\begin{array}{c}10 \text { most } \\
\text { profitable }\end{array}$ & $\begin{array}{l}10 \text { least } \\
\text { profitable }\end{array}$ \\
\hline Yield per acre (bushels) & 257 & $43 \overline{6}$ & $\overline{141}$ \\
\hline Fruit packed (percent) & 57 & percentage of total & 51 \\
\hline Age of bearing trees: & percent & percent & percent \\
\hline $\begin{array}{l}20 \text { years and under } \\
21-30 \text { years }\end{array}$ & $\begin{array}{l}18 \\
64 \\
18\end{array}$ & 21 & $\begin{array}{l}13 \\
62\end{array}$ \\
\hline 31 years and over and unclassified & percent & $\begin{array}{c}8 \\
\text { percentage of total } \\
\text { percent }\end{array}$ & percent \\
\hline $\begin{array}{l}\text { Distribution of varieties: } \\
\text { York } \\
\text { Stayman } \\
\text { Delicious } \\
\text { Grimes } \\
\text { Jonathan } \\
\text { Rome } \\
\text { Other }\end{array}$ & $\begin{array}{r}19 \\
14 \\
12 \\
8 \\
7 \\
5 \\
35\end{array}$ & $\begin{array}{r}23 \\
15 \\
15 \\
10 \\
6 \\
8 \\
23\end{array}$ & $\begin{array}{r}19 \\
18 \\
9 \\
7 \\
9 \\
5 \\
33\end{array}$ \\
\hline
\end{tabular}

Investment in:

$\begin{array}{ll}\text { Land } & 66 \\ \text { Orchard } & 86 \\ \text { Equipment } & 32 \\ \text { Buildings } & 46\end{array}$

Costs and returns

Gross returns

Costs

Production

Harvesting

Marketing

Overhead

Total costs

Net returns

\begin{tabular}{|c|c|c|c|c|c|}
\hline \multicolumn{2}{|c|}{ Per: $\quad 46$} & \multicolumn{2}{|r|}{56} & \multicolumn{2}{|c|}{ Per: 24} \\
\hline $\begin{array}{c}\text { Acre } \\
\text { dollars } \\
188\end{array}$ & $\begin{array}{c}\text { Bushel } \\
\text { cents } \\
72\end{array}$ & $\begin{array}{c}\text { Acre } \\
\text { dollars } \\
340\end{array}$ & $\begin{array}{c}\text { Bushel } \\
\text { cents } \\
78\end{array}$ & $\begin{array}{c}\text { Acre } \\
\text { dollars } \\
94\end{array}$ & $\begin{array}{c}\text { Bushel } \\
\text { cents } \\
66\end{array}$ \\
\hline $\begin{array}{l}36 \\
66 \\
32 \\
45\end{array}$ & $\begin{array}{l}14 \\
26 \\
12 \\
17\end{array}$ & $\begin{array}{r}54 \\
108 \\
59 \\
58\end{array}$ & $\begin{array}{l}12 \\
25 \\
14 \\
13\end{array}$ & $\begin{array}{l}26 \\
40 \\
16 \\
38\end{array}$ & $\begin{array}{l}19 \\
28 \\
11 \\
27\end{array}$ \\
\hline 179 & 69 & 279 & 64 & 120 & 85 \\
\hline 9 & 03 & 61 & 14 & -26 & -19 \\
\hline
\end{tabular}

It is noteworthy, for instance, that yearly yields for the most profitable orchards averaged 436 bushels per acre. This was 70 percent more than yields for all orchards studied and three times the average for the least profitable orchards, on which the yield was but 141 bushels per acre (Table 11).

While some of the differences in yields may be traced to variation in the age of trees, indications are that this item was not especially significant in explaining these differences. The discouraging aspects of apple production on the least profitable orchards may serve to explain why operators of these holdings were inclined to have fewer young trees. These growers also reported a larger proportion of old trees (31 years and over). 
Data relating to the distribution of varieties gave little additional basis for explaining differences in yields. The most profitable operators had slightly more York and Delicious trees, while the least profitable had relatively more Staymans and fewer Delicious. In no instances, however, were these differences significant. Neither did inherent characteristics of shale and limestone soil explain production differences. Two of the most profitable and three of the least profitable orchards were on shale soil.

It does seem significant, however, that on the least profitable orchards the investment per acre for equipment and buildings was only from one-half :o two-thirds that of the average for the 45 orchards studicd. In contrast, on the most profitable orchards these items were appreciably higher than the average. This suggests that for one reason or another the least profitable operators did not seem to have the equipment or facilities to do an adequate job of orcharding. This admittedly does not solve the riddle as to whether yields are low because facilities are inadequate or whether facilities are inadequate because yields are low. In any event, indications are that inadequate equipment, limited packing and storage facilities, and poor housing accommodations are attributes that go hand in hand with unprofitable orcharding. One may trace some difficulties to poor orchard management-management so indifferent, so inefficient, and so incompetent as to have no choice but the unsatisfactory living facilities found on some orchards.

Low yields coupled with a low percentage of packed fruit and consequently lower returns per bushel explained why gross returns per acre on the least profitable orchards were but one-fourth as high as on the most profitable operations. This situation also helps to explain why, even though expenses are but 45 percent as great, these operators lost $\$ 26$ per acre, while the most profitable operators had a net income of $\$ 61$ per acre (Table 11).

Consideration of per-bushel costs gives further significant comparisons. Harvesting and marketing items, being relatively fixed on a per-bushel basis, were much the same for both classes of orchards. It is understandable that "running the hills" looking for apples would cause harvesting costs to be higher on the low-producing, least profitable operations, just as less expenditure for packing material, storage, and commission largely explained why marketing costs were lower than average on these same orchards. The variable nature of production and overhead cost, when expressed on a bushel basis, was indicated by the fact that both were lower than average on the most profitable orchards and considerably higher than average on the least profitable ones.

\section{Comparisons of Selected Orchards}

Orchard No. 1: Orchard No. 1 comprises 22 acres in bearing apples and is a typically successful small-scale family operation. Except for a limited number of peach trees and a small poultry enterprise, apples constitute the only source of income. The orchard is located on Hagerstown limestone soil, has been capably managed, better than average attention has been given to cultural practices, and considerable flexibility has been evidenced in adjusting harvesting and marketing operations to changing economic conditions. Trees were described by the Land Appraisal Division of the Farm Credit Administration as of "good size" and as having made "good growth."

For the period studied average annual yield was 434 bushels per acre, or 67 percent above the average for all orchards (Table 12). Ninety-two percent 
TABLE 12-Summary of Significant Comparisons for Selected Apple Orchards in the Eastern Panhandle of West Virginia, 1938-1941

\begin{tabular}{|c|c|c|c|c|c|}
\hline \multirow{2}{*}{ Item } & \multicolumn{5}{|c|}{ Orchard number } \\
\hline & 1 & 2 & 3 & 4 & 5 \\
\hline Yield per acre (bushels) & 434 & 397 & 379 & 132 & 115 \\
\hline \multirow[t]{2}{*}{ Fruit packed (percent) } & 23 & 62 & 77 & 74 & 73 \\
\hline & \multicolumn{5}{|c|}{ percentage of total } \\
\hline \multicolumn{6}{|l|}{ Age of bearing trees: } \\
\hline 20 years and under & & 34 & 16 & $\ldots$ & 11 \\
\hline $21-30$ years & 92 & 46 & 76 & $\cdots$ & 88 \\
\hline \multirow[t]{2}{*}{31 years and over and unclassified } & 8 & 20 & 8 & 100 & 1 \\
\hline & \multicolumn{5}{|c|}{ percentage of total } \\
\hline \multicolumn{6}{|l|}{ Distribution of varieties: } \\
\hline York & 37 & 17 & 39 & 19 & 16 \\
\hline Stayman & 7 & 13 & 2 & 12 & 21 \\
\hline Delicious & ... & 22 & 3 & 48 & 11 \\
\hline Grimes & 5 & 2 & 6 & 10 & 8 \\
\hline Jonathan & $\because$ & $\cdots$ & 10 & $\ldots$ & 4 \\
\hline Rome & 13 & 2 & 3 & $\cdots$ & 4 \\
\hline Other & \multirow{2}{*}{\multicolumn{5}{|c|}{ dollars per acre }} \\
\hline Investment in : & & & & & \\
\hline Land & 75 & 75 & 45 & 62 & 35 \\
\hline Orchard & 88 & 91 & 67 & 92 & 76 \\
\hline Equipment & 92 & 42 & 48 & 43 & 10 \\
\hline Buildings & 50 & 39 & 44 & 94 & 13 \\
\hline & \multirow{2}{*}{\multicolumn{5}{|c|}{ dollars per acre }} \\
\hline $\begin{array}{l}\text { Costs and returns: } \\
\text { Per acre }\end{array}$ & & & & & \\
\hline Gross returns & 183 & 298 & 419 & 111 & 87 \\
\hline \multicolumn{6}{|l|}{ Costs } \\
\hline $\begin{array}{l}\text { Production } \\
\text { Harvesting }\end{array}$ & 45 & 48 & 64 & 49 & 28 \\
\hline $\begin{array}{l}\text { Harvesting } \\
\text { Marketing }\end{array}$ & $\begin{array}{l}49 \\
16\end{array}$ & $\begin{array}{l}92 \\
50\end{array}$ & $\begin{array}{r}114 \\
75\end{array}$ & $\begin{array}{l}51 \\
21\end{array}$ & $\begin{array}{l}39 \\
17\end{array}$ \\
\hline Overhead & 51 & 48 & 61 & 51 & 32 \\
\hline Total costs & 161 & 238 & 314 & 172 & 116 \\
\hline Net returns & 22 & 60 & $\begin{array}{c}105 \\
\text { nts per b }\end{array}$ & el -61 & -29 \\
\hline \multicolumn{6}{|l|}{ Per Bushel } \\
\hline $\begin{array}{l}\text { Gross returns } \\
\text { Costs }\end{array}$ & 42 & 75 & 111 & 84 & 76 \\
\hline $\begin{array}{l}\text { Costs } \\
\text { Production }\end{array}$ & 10 & 12 & 17 & 37 & \\
\hline Harvesting & 11 & 23 & 30 & 39 & 34 \\
\hline Marketing & 04 & 13 & 20 & 15 & 15 \\
\hline Overhead & 12 & 12 & 16 & 39 & 28 \\
\hline Total costs & 37 & 60 & 83 & 130 & 101 \\
\hline Net returns & 05 & 15 & 28 & -46 & -25 \\
\hline
\end{tabular}

of all bearing trees were in the 21- to 30-year age bracket-the period of highest production for most varieties in West Virginia. Variety distribution differed considerably from the average in that 50 percent of all trees were concentrated in two varieties-York and Rome.

Perhaps one of the most significant and unusual characteristics of the orchard operations of this grower was the fact that only 23 percent of the fruit produced was packed. During those years when relatively low prices prevailed, no fruit whatsoever was packed. In contrast, during the years of high prices the proportion packed was considerable. Since this grower had no packing shed of his own, all packing was done on a commercial basis. This may have served to restrict the extent of his packing, although indications are that he might not have been justified in maintaining such a shed for his small operation. The flexibility maintained in packing and in adjusting sales outlets to market demand has done much to contribute to profitable operation.

Examination of investment data indicates that, except for equipment, these items compared rather closely with averages for all orchards. The small 
acreage opcrated explained why equipment cxpense was higher than avcrage when expressed on a per-acre basis.

Data relating to costs and returns give further indication of why this orchard has made a creditable showing. Gross returns per acre have been maintained because of high production, while costs are somewhat less than average. Harvesting costs were low because of the small proportion of apples packed. This reduced expenditures for labor used in packing and for packing materials. Marketing costs were low because of the sale of a large proportion of apples to processing plants and to individuals doing their own packing. These outlets have enabled this grower to report charges that were significantly lower than average for such items as storage, commissions, and other closely related expenses.

Orchard No. 2: This orchard also is a family-type operation. It was considerably larger than Orchard No. 1, however, reporting 94 acres in bearing apples. It is situated predominantly on Frankstown limestone soil, but small amounts are on Hagerstown and Frederick. The average yield was 397 bushels per acre, of which 62 percent was packed (Table 12). Noteworthy was the fact that this operator had been able to maintain yields at a high level while reporting about one-third of all trees in the least productive age classification -20 years and under. The general condition of the orchard was described as "good." Variety distribution showed a larger than average proportion of Delicious trees while such varieties as Grimes and Rome were less common than usual. Investments per acre were only slightly above average for land, orchard, and equipment. They were below average for buildings.

High yields and higher than average returns per bushel combined to enable this operator to realize gross returns of $\$ 298$ per acre $-\$ 110$ above the average for the orchards studied. Harvesting and marketing costs per acre were higher than the average for all growers, primarily because of high production. These operations were efficiently conducted, however, and per-bushel costs were 3 cents less than the average for harvesting and but 1 cent higher for marketing. Higher marketing costs were explained largely by increased expenditures for packing materials, since a higher than average percentage of apples was packed. High yields per acre contributed to low variable production and overhead expense when expressed on a per-bushel basis. This also may be noted by examination of per-bushel costs, which shows that the former was 2 cents and the latter 5 cents below averages reported for the orchards studied. A net return of $\$ 60$ per acre, or 15 cents per bushel, is evidence of very capable orchard performance.

Orchard No. 3: Orchard No. 3 is a large corporation holding. It was characterized by yields 50 percent greater than the average, a high proportion of packed fruit ( 77 percent), lower than average proportion of trees in the 31 years-and-over age bracket (the result of a definite policy of removing aged trees), heavy concentration of York and Jonathan trees, and relatively few Stayman and Delicious trees (Table 12). Significant features of investments per acre were the lower value of land (but half that reported for all orchards) and a favorable comparison as to per-acre investments in orchard trees and overhead. Trees were described as "in excellent condition with good foliage, and nearly a perfect stand." Shale soils of the Meigs and Lehew series predominate. 
Examination of data relative to costs and returns shows very significant findings. Stress on quality production has resulted in gross returns per bushel being 35 percent above the average for all orchards studied. The combined influence of quality production and high yields per acre resulted in gross returns over twice the average for the orchards studied. Careful control of spraying, extensive application of fertilizer, and more than usual attention to pruning and cultural practices were factors that accounted for this orchard reporting per-bushel production costs that were about 20 percent above the average. Much the same relationship prevailed for harvesting costs, where stress on a quality pack served to increase these expenditures. Management reported that good distribution of varieties as to time of maturity permitted efficient utilization of labor in the picking operation. Before the building of their own storage this also was an important consideration as far as packing was concerned. Stress on effective distribution of quality fruit and the fact that a high proportion of apples was packed resulted in high costs for such items as storage, sales, and other closely related marketing expenses. Relatively low overhead costs have prevailed, primarily because of very capable management.

Orchard No. 4: This orchard is rather typical of the small orchards operated at a loss. It comprised 25 acres of bearing trees, is located on Hagerstown and Murrill limestone soil, and reported an average yield of 132 bushels per acre. Seventy-four percent of the apples produced were packed (Table 12). No definite information was available as to age of trees; variety distribution was significant in that 48 percent were Red and Golden Delicious. The small size of the operation has contributed to high investment charges for equipment, especially for buildings.

The history of this orchard indicates rather unsatisfactory performance. After several years of operation at a loss it was lost by its original owner, and management was taken over by one of the large operators in the area. Occasional frost damage and poor air and water drainage for about half of the orchard are other factors that have contributed to low returns. The report on soil condition made by the Land Appraisal Division of the Farm Credit Administration makes the following comment regarding this orchard: "the western one-third is on Murrill silt loam, poorly drained subsoil phase on an A slope (less than 2 percent) and very slight erosion. In places the middle and lower subsoil forms a hardpan-like layer that might at least retard root development."

Gross returns per acre were only 60 percent of that reported for all orchards studied, even though per-bushel returns were considerably higher than average (84 cents as compared with 72 cents). Total costs were only slightly less than those reported for all orchards. Harvesting and marketing costs, when expressed on a per-acre basis, were below average because of the tendency to vary directly with production. Production and overhead costs in contrast were above average. When these were expressed on a per-bushel basis, deviation from the average for all orchards was even more significant, being over twice that reported for all orchards. As would be expected, operations were at a loss. For the period studied these losses were $\$ 61$ per acre or 46 cents per bushel. 
Orchard No. 5: This orchard is one of the larger operations in the Eastern Panhandle. It is located on shale soil and has had capable management. For a period of years ownership has been of the absentee classification. Seventy-three percent of all fruit produced was packed, about 25 percent more than the average. Likewise the percentage of trees in the most productive age period21-30 years-was 88 percent as contrasted with but 64 percent for all orchards studied. Variety distribution corresponded closely with the distribution reported for all orchards. Soil is Dekalb shale silt loam and Lehew loam. Parts of the orchard did not have over 60 percent stand, and many trees were described as "small" and "stunted."

Investment per acre was low for all items, and for equipment and building it was appreciably below average. Likewise all costs on a per-acre basis were below average, particularly harvesting and marketing costs. This is explained in part because of less spraying and relatively low investments in production and overhead items.

When consideration is given to the fact that a high proportion of packed fruit contributes to high package, storage, and commission costs, and when recognition is given to the influence of low yield on harvesting expense, the increase in harvesting and marketing costs over averages for these items is reasonable. The low yield per acre for this orchard as well as for Orchard No. 4 serves to illustrate the variable nature of production and overhead costs, when these items are expressed on a per-bushel basis, and suggests that it is only through high yields that these costs can be kept low. Low yields per acre on these two orchards also are the primary reason why each reported operating losses for all four years.

\section{FACTORS CONTRIBUTING TO PROFITABLE APPLE PRODUCTION}

Findings in the preceding section have suggested that a number of factors have a bearing on profitable apple production in the Eastern Panhandle of West Virginia. The more important of these were: yield per acre, quality of apples produced, varieties of apples grown, soils selected for orchard sites, cultural practices undertaken, marketing methods followed, and qualifications of management.

The interrelationships that develop relative to the influence of these items on profitable orcharding are often very complex. What is more, it is impossible to segregate entirely the influence that management may have on any one. It is, of course, possible to examine the performance of one orchard, observe the influence of various productive factors, and note some of the important contributions of management. It is not readily possible, however, to ascertain what might be the accomplishments if the same combination of productive factors and the same management were moved from this orchard to another where operating conditions might be appreciably different. It is one thing to compare different orchards and quite another to evaluate various operating methods on the same farm. ${ }^{15}$

${ }^{15}$ For discussions of some commonly neglected considerations that apply to farm-management analysis see L. A. Salter, "Cross-Sectional and Case-Grouping Procedure in Research Analysis," Jour. Farm Econ., vol. XXIV, pp. 792-805, and S. A. Engene, "New Light on Factor Analysis," Ibid. vol. XXV. pD. 477-486. 
It also is known that joint relationships prevail in varying degrees among orchards. While low yiclds are closely related to such factors as soils, cultural practices, and varieties grown, the relative influence of each of these factors may, and in fact usually does, vary considerably from orchard to orchard. In other instances quality production is closely associated with ability to time critical operations effectively and to have the right equipment and adequate supplies for the tasks undertaken.

This section considers (1) relationship of yields to net returns, (2) influence of soil series, (3) relationship of size of orchard operation to profitability, (4) influence of selected cultural practices, (5) marketing methods, and (6) the role of management.

\section{Relationship of Yields to Net Returns}

Data presented in Table 13 give comparisons for orchards classified according to production per acre of bearing fruit. Those orchards reporting less than 200 bushels of apples per acre were characterized by: (1) a low proportion of young trees, (2) low per-acre investments in buildings and equipment, and (3) low per-acre and high per-bushel costs-all factors which contributed to a loss of 24 cents on every bushel of apples produced. Orchards in the 200-300-bushel-per-acre classification varied from the average for all orchards studied with respect to (1) a somewhat lower than average proportion of packed fruit, (2) a smaller proportion of trees in the 21-30-year age bracket, (3) a larger proportion of old and unclassified trees, (4) low gross returns per bushel (to a large extent due to the low proportion of fruit packed), and (5) a small loss on each bushel of apples produced. The combination of high yields and higher than average prices per bushel of apples sold enabled growers producing 300 bushels or more of apples per acre to show a profit of 13 cents per bushel or $\$ 55$ per acre. As a class this was the only group of orchards that reported a profit. Another significant feature of these orchards was the high per-acre investment in equipment and buildings. It has been indicated that such investments are characteristic of operations that give more than average attention to the production, packing, and storage problems of orcharding.

High yield has contributed to low variable costs per bushel. Harvesting and marketing costs were relatively fixed, ranging from 27 cents per bushel on the high-producing orchards to 33 cents per bushel on the low-producing orchards. Production and overhead items amounted to but 25 cents a bushel on orchards producing over 300 bushels per acre and 53 cents on orchards producing under 200 bushels per acre (Table 13). This represents a difference of 28 cents in per-bushel costs and suggests that yield is the most important factor in contributing to low production costs and consequently in enabling growers to realize profitable apple production.

These findings suggest that it is important for growers to consider the various factors that contribute to high yields. Such factors as age of trees, varieties grown, soil series, and degree of erosion-all are items that influence orchard productivity. In addition such further consideration as total rainfall, seasonal distribution of rainfall, relationship between precipitation and run-off, hail, and frost are factors beyond the control of management. These can be and are very important in determining year-to-ycar apple production and the consequent profit or loss reflected by such production. 
TABLE 13-Summary of Significant Comparisons of Bearing Apple Orchards in the Eastern Panhandle of West Virginia, Classified According to Production, 1938-1941

\begin{tabular}{|c|c|c|c|c|c|c|c|c|}
\hline \multirow[b]{2}{*}{ Item } & \multirow{2}{*}{\multicolumn{2}{|c|}{$\begin{array}{l}\text { Average } \\
\text { all } \\
\text { orchards }\end{array}$}} & \multicolumn{6}{|c|}{ Production per acre } \\
\hline & & & \multicolumn{2}{|c|}{$\begin{array}{l}\text { Under } 200 \\
\text { bushels }\end{array}$} & \multicolumn{2}{|c|}{$\begin{array}{l}200 \text { to } 300 \\
\text { bushels }\end{array}$} & \multicolumn{2}{|c|}{$\begin{array}{l}300 \text { bushels } \\
\text { and over }\end{array}$} \\
\hline Number of orehards & \multicolumn{2}{|l|}{45} & \multirow{2}{*}{\multicolumn{2}{|c|}{14}} & \multicolumn{2}{|c|}{16} & \multicolumn{2}{|c|}{15} \\
\hline Average yield per acre (bushels) & \multirow{2}{*}{\multicolumn{2}{|c|}{$\begin{array}{r}257 \\
57\end{array}$}} & & & \multicolumn{2}{|c|}{228} & \multicolumn{2}{|r|}{428} \\
\hline Proportion packed (percent) & & & \multirow{2}{*}{\multicolumn{4}{|c|}{$\begin{array}{lr}58 & 48 \\
\text { percentage of total }\end{array}$}} & \multirow{2}{*}{\multicolumn{2}{|c|}{61}} \\
\hline & & & & & & & \\
\hline \multicolumn{9}{|l|}{ Distribution of bearing trees: } \\
\hline 20 years and under. & \multicolumn{2}{|c|}{ percent } & \multicolumn{2}{|c|}{ percent } & \multicolumn{2}{|c|}{ percent } & \multicolumn{2}{|c|}{ percent } \\
\hline $21-30$ years & \multicolumn{2}{|c|}{64} & \multicolumn{2}{|c|}{$\begin{array}{r}9 \\
76\end{array}$} & \multicolumn{2}{|c|}{23} & & 71 \\
\hline 31 years and over and unclassified & \multicolumn{2}{|c|}{18} & 15 & & & 33 & & 9 \\
\hline & & & & ercenta & ge of tot & tal & & \\
\hline & perce & & perce & ent & perc & cent & & ercent \\
\hline Distribution of varieties: & & & & & & & & \\
\hline York & 19 & & 19 & & & 22 & & 20 \\
\hline Stayman & 14 & & 18 & & & 14 & & 16 \\
\hline Delicious & 12 & & g & 9 & & 13 & & 15 \\
\hline Grimes & 8 & & & 8 & & 6 & & 12 \\
\hline Jonathan & 7 & & 10 & & & 5 & & 6 \\
\hline Rome & 5 & & & 6 & & 3 & & 7 \\
\hline Others & 35 & & 30 & & & 37 & & 24 \\
\hline & & & & dollars & per acr & & & \\
\hline Investment per acre in: & & & & & & & & \\
\hline Land & 66 & & 57 & & & 70 & & 69 \\
\hline Orchard & 86 & & 81 & & & 88 & & 88 \\
\hline Equipment & 32 & & 26 & & & 25 & & 45 \\
\hline Buildings & 46 & & 21 & & & 50 & & 64 \\
\hline & & er: & pel & & & er : & & er: \\
\hline Costs and returns & $\begin{array}{l}\text { acre } \\
\text { dollars }\end{array}$ & $\begin{array}{c}\text { bushel } \\
\text { cents }\end{array}$ & $\begin{array}{c}\text { acre } \\
\text { dollars }\end{array}$ & $\begin{array}{l}\text { bushel } \\
\text { cents }\end{array}$ & $\begin{array}{l}\text { acre } \\
\text { dollars }\end{array}$ & $\begin{array}{c}\text { bushel } \\
\text { cents }\end{array}$ & $\begin{array}{l}\text { acre } \\
\text { dollars }\end{array}$ & $\begin{array}{c}\text { bushel } \\
\text { cents }\end{array}$ \\
\hline Gross returns & $188^{\circ}$ & 72 & 81 & 72 & 150 & 65 & 321 & 75 \\
\hline Cost & & & & & & & & \\
\hline Production & 36 & 14 & 24 & 21 & 32 & 14 & 52 & 12 \\
\hline Harvesting & 66 & 26 & 34 & 30 & 57 & 25 & 103 & 24 \\
\hline Marketing & 32 & 12 & 14 & 13 & 24 & 10 & 56 & 13 \\
\hline Overhead & 45 & 17 & 35 & 32 & 43 & 19 & 55 & 13 \\
\hline Total costs & 179 & 69 & 107 & 96 & 156 & 68 & 266 & 62 \\
\hline Net returns & 9 & 03 & -26 & -24 & -6 & -03 & 55 & 13 \\
\hline
\end{tabular}

The degree to which each factor is important on individual orchards varies considerably. Individual growers, too, have followed a variety of practices tc find the most effective combination for their particular holdings. Operators on soils with inherently low fertility may find that attention to such matters as production of quality fruit, increased operating efficiency, and search for better markets may pay greater dividends than attempting to follow cultural practices found successful on farms with more productive soil. Likewise, whilc growers of high-quality fruit may obtain greatest returns by giving careful attention to packing methods and to development of market outlets, producers of low-quality fruit, in contrast, may be further ahead by seeking outlets through local buyers and processors and thus avoiding uneconomical expenditures for packing and marketing - expenditures not justified by the increased returns from relatively poor fruit.

The relationship of yield to profitable operation is shown by the distribution of operators according to whether or not their records showed a profit. Classified according to yield per acre this distribution was as follows:

\begin{tabular}{|c|c|c|c|}
\hline Yield & Average & \multicolumn{2}{|c|}{ Operators reporting a : } \\
\hline Per acre & yield & Profit & Loss \\
\hline bushels & bushels & number & number \\
\hline Under 200 & 112 & 2 & 12 \\
\hline $200-300$ & 228 & 7 & 9 \\
\hline Over 300 & 428 & 13 & 2 \\
\hline
\end{tabular}




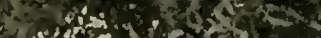




\section{The Influence of Soil Series}

Soil series is considered one of the significant factors contributing to differences in yields and to variations in net returns from the apple enterprise. Soils are basically important from the standpoint of natural fertility and moisture-absorbing and holding ability. More indirectly, soils because of their location may reflect such matters as topography, susceptibility to frost, extent of rainfall, likelihood of hail damage, and accessibility to markets. This section considers the influence of soils on apple yields and returns from the following standpoints: (1) comparison of shale and limestone soils, (2) comparison of Hagerstown and Frankstown limestone soils, and (3) relationship of the degree of erosion to orchard performance.

Comparison of Shale and Limestone Soils: Studies have indicated that as a general rule orchards are likely to be more productive and profitable when situated on limestone soil. ${ }^{16}$ The specific findings of this study do not lend themselves to detailed quantitative measurements as to the relative merits of these two classes of soils for orchard production. The fact that many of the less successful apple orchards located on shale soil have already ceased or restricted commercial operation and the fact that some of the more successful ones are included explain why such comparisons are not stressed. Sufficient information, however, has been obtained to get reasonably good measure of the range of possibilities on these types of soil.

Data presented in Table 14 give comparisons for the most profitable and the least profitable orchards situated on shale and limestone soils. For the orchards studied it is significant that all those on shale soil reported an average yield only 58 percent as high as for all orchards on limestone soil. While yields on most profitable orchards were relatively high, irrespective of parent soil materials, the least profitable orchards on shale soil reported a yield but slightly more than one-third that of the most profitable orchards on shale soils and but two-fifths the production of the least profitable orchards on limestone soil.

In all instances the proportion of fruit packed on shale soils was greater. Better color and less damage from codling moth were important factors contributing to the favorable position of orchards on shale with respect to packout.

Consideration of costs and returns shows that it is possible for the more efficiently operated orchards situated on shale soil to show as creditable a performance as the profitable ones on limestone soil. The extent to which this may be due to exceptional management or to sites that may be better than

\footnotetext{
${ }^{16}$ M. A. Abrahamsen, A Labor Income Study of Orchard Farms in the Eastern Panhandle of West Virginia (with a special reference to apple production), W. Va. Agr. Expt. Sta. Mim. Cir. No. 27. Jan. 1938. In a labor-income investigation of apple orchards for 1936 this study reported that but 15 out of 35 commercial orchards on shale soil reported a plus labor income, while 40 out of 53 orchards on limestone soil reported a plus labor income. This study also reportel average vields in 1936 of 236 bushels per acre for 142 orchards located on limestone as compared with yields of 90 bushels per acre for 98 orchards located on shale soil.

See also G. M. Browning and R. H. Sudds, Some Physical and Chemicul Properties of the Principal Orchard Soils in the Eastern Panhandle of West Virginia. W. Va. Agr. Expt. Sta. Bul. 303. March 1942. This study reports: "A few commercial apple and peach orchards are being operated with a fair degree of success on the relatively shallow sandstone and shale soils. However, the location of new orchards cannot be generally recommended on any other than the superior deeper phases of these soils, and then it should be realized that the hazards of drouth are relatively much more than on the deeper soils and that good soil-management practices, including water conservation, must be exercised if any consistent degree of success is to be obtained." (p. 51.)
} 
TABLE 14-Comparison of Most Profitable and Least Profitable Orchards on Shale and Limestone Soils, Eastern Panhandle of West Virginia, 1938-1941

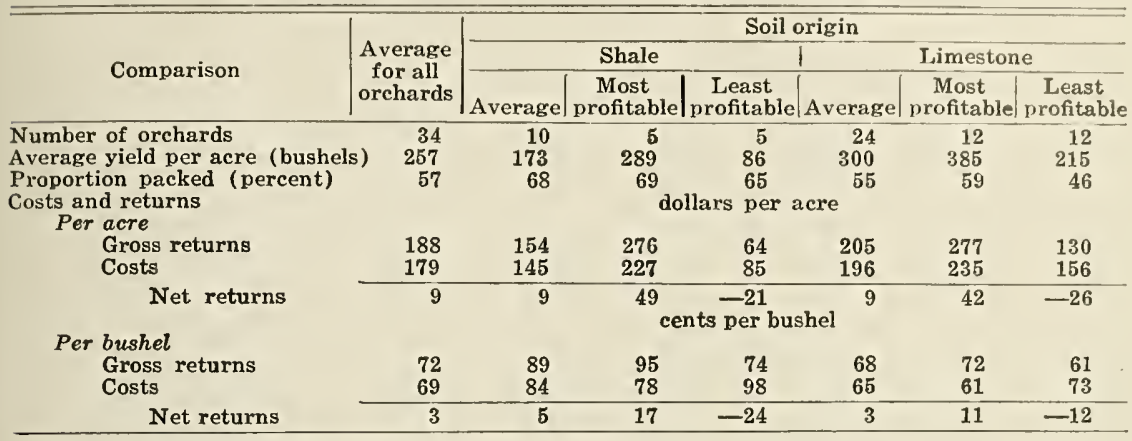

average is not easy to say. Indications are, however, that these items were important contributing factors. While per-acre losses on the least profitable orchards were much the same irrespective of soil series, per-bushel losses for apples produced on shale soil were 24 cents as compared with 12 cents for those grown on limestone-a factor explained primarily because of differences in yields.

Except for differences in harvesting and marketing costs, items largely explained by variations in yields and in the proportion of fruit packed, there was little difference in other costs for orchards on shale and limestone soils. Exceptions were expenditures for spray material and pruning. Lower per-acre expenditures for these items on shale soil, primarily because of lower infestation of codling moth and the less rapid growth of trees, practically accounted for all the differences in per-acre production costs which were $\$ 29$ for orchards on shale soil and $\$ 41$ for orchards on limestone soil (Table 14). Not unlike various series of limestone soil, wide differences exist in the suitability for apple production on the different series of shale soil. Sufficient data were not available, however, to make a comparison of orchard performance on various series of shale soils.

Comparison of Frankstown and Hagerstown Limestone Soils: Differences exist as to beliefs regarding the respective advantages of Frankstown and Hagerstown soil for orchard purposes. Browning and Sudds report that "when all three limestone soils (Frankstown, Hagerstown, and Frederick) were closely associated on similar topography in the same orchard ... there was no apparent difference between the trees on each series." ${ }^{17}$ Other observers have expressed the opinion that Hagerstown soil has certain advantages over the somewhat lighter Frankstown soil in that trees on this soil have shown greater ability to withstand prolonged dry spells.

Data presented in Table 15 are given, not as definite proof of the superiority of either type of limestone soil for orchard purposes, but rather as an indication of performance under varying degrees of profitability. Of the orchards studied, those on Frankstown soil reported somewhat higher yields than did those on Hagerstown soil, although variation was greater between the most and the least profitable orchards on the former soil than on the latter.

${ }^{17}$ G. M. Browaing and R. H. Sudds, idem, p. 24. 
Pach-out averaged the same for orchards on both kinds of soil and was significantly higher for the most profitable orchards as compared with the least profitable ones.

Gross income per acre varied with yields and with the proportion of fruit packed. Similarly, costs showed the usual relationship prevailing for orchards grouped according to low and high production. The least profitable orchards reported losses irrespective of soil. These data suggest that good managers are likely to do a creditable job regardless of the class of soil among these two on which they may locate and, similarly, that poor managers seem to show unprofitable operation as readily on one soil as on the other. As has been indicated, it is necessary to go further than merely determining soil serics and class when selecting an orchard site.

The proportion of dying trees and missing spaces in an orchard as well as the number of spaces in bearing and nonbearing trees may be used as an indication of the status of orcharding. It does seem significant that, contrary to

TABLE 15-Comparison of Most Profitable and Least Profitable Orchards Classified According to Limestone Soil Series, Eastern Panhandle of West Virginia, 1938-1941

\begin{tabular}{|c|c|c|c|c|c|c|c|}
\hline \multirow{3}{*}{ Comparison } & \multirow{3}{*}{$\begin{array}{l}\text { Average } \\
\text { all1 } \\
\text { limestone }\end{array}$} & \multicolumn{6}{|c|}{ Limestone soil series } \\
\hline & & \multicolumn{3}{|c|}{ Frankstown } & \multicolumn{3}{|c|}{ Hagerstown } \\
\hline & & Average & $\mid \begin{array}{c}\text { Most } \\
\text { profitable }\end{array}$ & $\left|\begin{array}{c}\text { Least } \\
\text { profitable }\end{array}\right|$ & Average & $\mid \begin{array}{c}\text { Most } \\
\text { profitable }\end{array}$ & $\mid \begin{array}{c}\text { Least } \\
\text { profitable }\end{array}$ \\
\hline Number of orchards & 36 & 10 & 5 & 5 & 14 & 7 & 7 \\
\hline Yield per acre (bushels) & 300 & 349 & 432 & 213 & 276 & 314 & 237 \\
\hline Proportion packed (percent) & 55 & 50 & 53 & 41 & 50 & 54 & 45 \\
\hline \multirow{2}{*}{\multicolumn{8}{|c|}{$\begin{array}{c}\text { Costs and returns } \\
\text { Per acre }\end{array}$}} \\
\hline & & & & & & & \\
\hline Gross returns & 205 & 221 & 281 & 123 & 176 & 213 & 140 \\
\hline Cost & 196 & 198 & 235 & 136 & 185 & 197 & 174 \\
\hline $\begin{array}{c}\text { Net returns } \\
\text { Per bushel }\end{array}$ & 9 & 23 & 46 & $\begin{array}{c}-13 \\
\text { cents per bu }\end{array}$ & ushel & 16 & -34 \\
\hline Gross returns & 68 & 63 & 65 & 58 & 64 & 68 & 59 \\
\hline Costs & 65 & 57 & 54 & 64 & 67 & 63 & 73 \\
\hline Net returns & 3 & 6 & 11 & -6 & -3 & 5 & -14 \\
\hline
\end{tabular}

${ }^{1}$ Includes 2 orchards on Frederick soil and 10 orchards not lending themselves to limestone-soil classification.

general opinion, for the orchards studied, shale and Frankstown sites show a relatively low proportion of dying and missing trees as well as a high proportion of nonbearing trees, while orchards on Hagerstown and Frederick did not compare as favorably in these respects. In this connection the influence of consecutive years in apple production as a factor is in need of further rescarch, since the relative susceptibility to certain insect and disease infestations might account for significant differences on those soils that have been in apple production for the greatest number of ycars. Grouped according to soil origin and series, the distribution of spaces was reported as follows:

Percentage distribution of total spaces for:

\begin{tabular}{lccccc} 
& All & All shale & \multicolumn{3}{c}{ Orchards on limestone } \\
Space & orchards & orchards & Frankstown & Hagerstown & Frederick. \\
distribution & percenl & percent & percent & percent & percenl \\
Bearing & 73 & 71 & 75 & 77 & 57 \\
Nonbearing & 22 & 26 & 20 & 14 & 32 \\
Dying & 1 & 1 & 1 & 1 & 3 \\
Missing & 4 & 2 & 4 & 8 & 8
\end{tabular}


The Relationship of Erosion to Orchard Performance: The degree of erosion varies widely among orchards in the Eastern Panhandle of West Virginia. Comparisons for orchards classified as to degree of crosion are shown in Table 16. As would be expected, yields were higher on orchards classified as having slight erosion-ranging from 314 bushels per acre on those orchards to 217 bushels on those classified as severely eroded. It seems important, however, to note that even on some orchards classified as severely eroded profitable yiclds were obtained. In fact, the most profitable orchards in the severely croded classification made the most creditable showing of any group-having net returns of $\$ 51$ per acre or 14 cents per bushel.

On a per-acre basis the least profitable orchards were about equally unsuccessful irrespective of degree of erosion. When comparisons were made for all orchards in each class, however, it may be noted that orchards with slight

TABLE 16-Comparison of Most Profitable and Least Profitable Orchards Classified According to Degree of Erosion, Eastern Panhandle of West Virginia, 1938-1941

\begin{tabular}{|c|c|c|c|c|c|c|c|c|c|}
\hline \multirow[b]{3}{*}{ Comparison } & \multicolumn{9}{|c|}{ Degree of erosion } \\
\hline & & Slight & 1 & Mo & derate & & & evere & \\
\hline & Average & $\mid \begin{array}{l}\text { Most } \\
\text { prof- } \\
\text { itable }\end{array}$ & $\left|\begin{array}{l}\text { Least } \\
\text { prof- } \\
\text { itable }\end{array}\right|$ & Average & $\mid \begin{array}{c}\text { Most } \\
\text { prof- } \\
\text { itable }\end{array}$ & $\left|\begin{array}{l}\text { Least } \\
\text { prof- } \\
\text { itable }\end{array}\right|$ & Average & $\mid \begin{array}{c}\text { Most } \\
\text { prof- } \\
\text { itable }\end{array}$ & $\begin{array}{l}\text { Least } \\
\text { prof- } \\
\text { itable }\end{array}$ \\
\hline Number of orchards & 16 & 8 & 8 & 11 & 6 & 5 & 4 & 2 & 2 \\
\hline Yie'd per acre (bu & 314 & 347 & 226 & 271 & 295 & 221 & 217 & 383 & 125 \\
\hline Proportion packed (percent) & 54 & 63 & 46 & 57 & 59 & 51 & 67 & 63 & 72 \\
\hline $\begin{array}{l}\text { Costs and returns } \\
\text { Per acre }\end{array}$ & & & & dollars & s per a & cre & & & \\
\hline Gross returns & 209 & 270 & 131 & 198 & 223 & 143 & 156 & 259 & 98 \\
\hline Costs & 198 & 233 & 154 & 188 & 200 & 162 & 153 & 208 & 122 \\
\hline $\begin{array}{l}\text { Net returns } \\
\text { Per bushel }\end{array}$ & 11 & 37 & -23 & $\begin{array}{l}10 \\
\text { cents } p\end{array}$ & $\begin{array}{l}23 \\
\text { per bus }\end{array}$ & -19 & 3 & 51 & -24 \\
\hline Gross returns & 66 & 78 & 58 & 73 & 76 & 65 & 72 & 68 & 79 \\
\hline Costs & 63 & 67 & 68 & 69 & 68 & 73 & 71 & 54 & 98 \\
\hline Net returns & 3 & 11 & -10 & 4 & 8 & -8 & 1 & 14 & -19 \\
\hline
\end{tabular}

erosion did somewhat better than those in the other two classifications. Indications are that, while the selection of a site on soil but slightly eroded is no assurance of successful orchard operation, the average grower stands a better chance of being successful there than on soils more severely eroded.

\section{The Relationship of Size of Orchard Operations to Profitability}

It is a generally accepted truism that large agricultural enterprises offer possibilities of greatest profit or loss. This fact is well illustrated by data presented in Table 17. About half of the orchards reported profitable operation irrespective of size classification, but both large profits and large losses were on the large orchards. Experience in the apple industry during the past decade also substantiates the commonly accepted view that operators of large farms made larger profits than operators of small farms during "good times" and that during "poor times" they sustained greater losses.

Except for the smallest size classification (under 50 acres), there was a tendency for the most profitable orchards to pack a greater proportion of fruit. The fact that this was not the case for the smaller orchards suggests that they may not have had as good market outlets for packed apples as did the larger ones or else they did not take the trouble to find them. 
TABLE 17-Comparison of Orchards Classified as to Size, Eastern Panhandle of West Virginia, 1938-1941

\begin{tabular}{|c|c|c|c|c|c|c|c|c|c|}
\hline \multirow{3}{*}{ Item } & \multicolumn{9}{|c|}{ Size classification (acres) } \\
\hline & \multicolumn{3}{|c|}{ Under 50} & \multicolumn{3}{|c|}{$50-99$} & \multicolumn{3}{|c|}{100 and over } \\
\hline & Average & $\begin{array}{l}\text { Prof- } \\
\text { itable }\end{array}$ & $\begin{array}{c}\text { Unprof- } \\
\text { itable }\end{array}$ & Average & $\begin{array}{l}\text { Prof- } \\
\text { itable }\end{array}$ & $\begin{array}{c}\text { Unprof- } \\
\text { itable }\end{array}$ & Average & $\begin{array}{l}\text { Prof- } \\
\text { itable }\end{array}$ & $\begin{array}{l}\text { Unprof- } \\
\text { itable }\end{array}$ \\
\hline $\begin{array}{l}\text { Number of } \\
\text { orchards } \\
\text { Average size }\end{array}$ & 16 & 8 & 8 & 15 & 7 & 8 & 14 & 6 & 8 \\
\hline (acres) & 32 & 32 & 32 & 71 & 76 & 66 & 181 & 186 & 178 \\
\hline $\begin{array}{l}\text { Yield per acre } \\
\text { (bushels) } \\
\text { Proportion of }\end{array}$ & 232 & 274 & 189 & 313 & 377 & 229 & 245 & 379 & 140 \\
\hline $\begin{array}{l}\text { fruit packed } \\
\text { (percent) }\end{array}$ & 51.0 & 49.5 & 53.2 & 54.5 & 58.4 & 46.3 & 58.9 & 62.9 & 50.6 \\
\hline $\begin{array}{c}\text { Cost and return } \\
\text { Per acre } \\
\text { Gross }\end{array}$ & & & & bll & lars per a & re & & & \\
\hline $\begin{array}{l}\text { returns } \\
\text { Costs }\end{array}$ & & $\begin{array}{l}181 \\
165\end{array}$ & $\begin{array}{l}125 \\
147\end{array}$ & $\begin{array}{l}209 \\
204\end{array}$ & $\begin{array}{l}266 \\
231\end{array}$ & $\begin{array}{l}134 \\
168\end{array}$ & $\begin{array}{l}185 \\
173\end{array}$ & $\begin{array}{l}306 \\
250\end{array}$ & $\begin{array}{r}92 \\
113\end{array}$ \\
\hline $\begin{array}{l}\text { Net re- } \\
\text { turns } \\
\text { Per bushel }\end{array}$ & -3 & 16 & -22 & $\begin{array}{l}5 \\
\text { cent }\end{array}$ & $\begin{array}{c}35 \\
\text { ts per bu }\end{array}$ & hel 34 & 12 & 56 & -21 \\
\hline $\begin{array}{l}\text { Gross } \\
\text { returns } \\
\text { Costs }\end{array}$ & $\begin{array}{l}66.0 \\
67.1\end{array}$ & $\begin{array}{l}66.0 \\
60.2\end{array}$ & $\begin{array}{l}66.1 \\
77.8\end{array}$ & $\begin{array}{l}66.8 \\
65.2\end{array}$ & $\begin{array}{l}70.5 \\
61.3\end{array}$ & $\begin{array}{l}58.5 \\
73.4\end{array}$ & $\begin{array}{l}75.5 \\
70.6\end{array}$ & $\begin{array}{l}80.7 \\
66.0\end{array}$ & $\begin{array}{l}65.7 \\
80.7\end{array}$ \\
\hline $\begin{array}{l}\text { Net } \\
\text { returns }\end{array}$ & s -1.1 & 5.8 & -11.7 & 1.6 & & -14.9 & 4.9 & 14.7 & -15.0 \\
\hline $\begin{array}{c}\text { Per farm } \\
\text { Gross }\end{array}$ & & & & re $\mathrm{xg}$ & $\mathrm{m}^{2}+2$ & doll & & & \\
\hline $\begin{array}{l}\text { income } \\
\text { Cost }\end{array}$ & $\begin{array}{l}4,925 \\
5,011\end{array}$ & $\begin{array}{l}5,873 \\
5,348\end{array}$ & $\begin{array}{l}8,979 \\
4,675\end{array}$ & $\begin{array}{l}14,865 \\
14,499\end{array}$ & $\begin{array}{l}20,139 \\
17,493\end{array}$ & $\begin{array}{r}8,837 \\
11,076\end{array}$ & $\begin{array}{l}33,649 \\
31,402\end{array}$ & $\begin{array}{l}56,751 \\
46,454\end{array}$ & $\begin{array}{l}16,321 \\
20,112\end{array}$ \\
\hline Net & -86 & $52 \overline{5}$ & -696 & 366 & 2,646 & $-2,239$ & 2,247 & 10,297 & $-3,791$ \\
\hline
\end{tabular}

Yields were somewhat greater for orchards in the 50-99-acre size classification. This likely was due to a tendency for more intensive operation of these holdings by some of the better growers. Indications are that higher returns on the larger operations can be traced primarily to the influence of a larger proportion of packed fruit and the tendency to devote more attention to the development of market outlets.

Findings of this study suggest that size of operation had little influence on per-acre or per-bushel losses incurred on the unprofitable operations (Table 17). In contrast, profitable operations reported progressively higher returns per acre and per bushel as the size of orchards increased. The same relationships prevailed when averages for each size classification were compared.

\section{Influence of Selected Operating Practices}

Certain operating practices followed by apple producers in the Eastern Panhandle have a marked influence on possibilities of success in orcharding. This section gives attention to the influence of three of these practices. They are: (1) variety plantings of bearing and nonbearing apple trees, (2) influence of the number of trees per acre of bearing apples on orchard performance, and (3) variety comparisons.

$V$ ariety Plantings of Bearing and Nonbearing Apple Trees: The percentage distribution of bearing and nonbearing apple trees is indicated in Table 18. Five varieties-York, Stayman, Delicious, Grimes, and Jonathan-accounted for approximately two-thirds of the trees in production. This is in accordance with findings of a previous study which indicated that these varieties were the most important ones grown in the state. Compilation of data reported in that 
study also indicated that on orchard farms the percentage of varieties classified according to time of maturity as "late," "medium," and "early," respectively, was 63,31 , and 6 percent. ${ }^{18}$

Golden Delicious, Rome, and Northwestern Greenings were varieties that showed a marked increase in the proportion of nonbearing trees as compared with bearing trees. York, Stayman, Delicious, and Jonathan showed little differences as to the relative importance of bearing and nonbearing trees. Significant declines in the proportion of nonbearing as compared with bearing trees were reported for the following varieties: Grimes, Ben Davis, Black Twig, Winesap, Maiden Blush, Yellow Transparent, and Wealthy. These findings indicate that during the next two decades the distribution of major varieties in full production will not be significantly different from what it is at the present time; such varieties as York, Stayman, Delicious, Jonathan, and Rome will predominate (Table 18).

TABLE 18-Percentage Distribution of Bearing and Nonbearing Apple Trees as Reported by 45 Apple Growers in the Eastern

Panhandle of West Virginia ${ }^{1}$

\begin{tabular}{lcc}
\hline \multicolumn{1}{c}{ Variety } & \multicolumn{2}{c}{ Percentage of total } \\
\cline { 2 - 3 } York & Bearing & percent \\
Stayman & percent & 22.2 \\
Delicious & 21.5 & 15.6 \\
Golden Delicious & 15.9 & 11.0 \\
Grimes & 11.9 & 7.0 \\
Ben Davis & 2.0 & 4.3 \\
Rome & 9.2 & 1.7 \\
Black Twig & 5.5 & 15.2 \\
Jonathan & 5.6 & 0.5 \\
Winesap & 3.8 & 7.7 \\
Yellow Transparent & 7.8 & 2.1 \\
N. W. Greening & 3.5 & 0.7 \\
Maiden Blush & 2.9 & 3.8 \\
Wealthy & 2.5 & 0.3 \\
Other & 1.1 & 7.9
\end{tabular}

${ }^{1}$ Counts on individual orchards were made during the 1939 , the 1940 , and, in a few instances, the 1941 seasons.

Number of Trees Per Acre of Bearing Apples: Widely different views have been expressed as to the advantages or disadvantages of having a high number of bearing trees per acre. It is evident that the influence of such factors as soil, degree of erosion, varieties, and ability of management to a marked extent will influence the number of bearing trees per acre that operators can handle effectively. Data presented in Table 19 give comparisons for orchards classified according to the number of bearing apple trees per acre. ${ }^{19}$

Orchards were classified into three groups on the basis of the number of trees per acre of bearing fruit-those reporting under 40 trees, 40-50 trees, and over 50 trees. It is significant that yields per acre on apple orchards having over 50 trees per acre of bearing fruit were nearly 70 percent higher

1.R. S. Marsh and M. A. Abrahamsen, Apple Varieties and the Age of Trees. W. Va. Agl'. Expt. Sta. Mim. Cir. No. 36. Mareh 1939.

19I is interesting that these findings are the opposite of those in New York, where it was reported that "one of the greatest enemies of the apple orchard ... is the apple tree" (G. F. Warren. Cornell Univ. Agr. Expt. Sta. Bul. 226, p. 299, 1905). This study reported that orchards with less than 35 trees per acre yielded 229 bushels per acre as compared with 186 bushels for orchards with 48 or more trees per acre. Likewise a study of the Newfane-O'cott area in New York showed an arerage yield of 162 bushels of packed fruit with less than 30 trees as compared with 123 bushels for orchards with over 40 trees (T. E: La Mont and Paul Williamson. Cornell Univ. Ext. Bul. $355,1936)$. 
than on orchards having under 40 trees per acre. The percentage of apples packed (52 percent) also was relatively low for those holdings reporting less than 40 trees per acre. The proportion was higher for the two other classifications - averaging 59 percent for each. Likewise it is significant that production per tree was much the same for all three groups (Table 19).

While spray material costs were relatively higher on a per-acre basis for those orchards having over 50 trees per acre of bearing apples, they were not higher when expressed on a per-bushel basis. They were significantly lower on a per-tree basis ( 36 cents per tree for orchards having 50 trees or more per acre as compared with 48 cents per tree on orchards having under 40 trees per acre).

Examination of data relating to costs and returns indicates that there was little difference in net returns per acre in the two classifications reporting the highest concentration of trees per acre. Orchards having 40-50 trees per acre of bearing fruit had net returns of $\$ 19$ per acre, while orchards having over 50 trees per acre had net returns of $\$ 21$ per acre. In contrast, orchards having fewer than 40 trees showed a net loss of $\$ 11$ per acre. This was equivalent to a loss of 5 cents per bushel or 16 cents per tree as contrasted with a profit of 6 cents per bushel and 55 cents per tree on orchards with over 50 trees per acre.

TABLE 19-Comparisons for Apple Orchards in the Eastern Panhandle of West Virginia Classified According to the Number of Bearing Trees

Per Acre of Bearing Fruit as Reported for 1938-1941 ${ }^{1}$

\begin{tabular}{|c|c|c|c|}
\hline \multirow[b]{2}{*}{ Item } & \multicolumn{3}{|c|}{ Number of trees per acre of bearing fruit } \\
\hline & $\begin{array}{c}\text { Under } \\
40\end{array}$ & $40-50$ & $\begin{array}{l}50 \text { and } \\
\text { over }\end{array}$ \\
\hline Number of orchards & 16 & 18 & 11 \\
\hline Yield per acre (bushels) & 209 & 267 & 348 \\
\hline Proportion of fruit packed (percent) & 52 & 59 & 59 \\
\hline Bealing trees per acre & 34 & 46 & 61 \\
\hline Production per tree (bushels) & 6.1 & 5.8 & 5.7 \\
\hline $\begin{array}{l}\text { Costs and returns } \\
\text { Per acre }\end{array}$ & \multicolumn{3}{|c|}{ dollars per acre } \\
\hline $\begin{array}{l}\text { Gross returns } \\
\text { Costs }\end{array}$ & 144 & $\begin{array}{l}199 \\
180\end{array}$ & $\begin{array}{l}243 \\
222\end{array}$ \\
\hline Net returns & -11 & -19 & $2 \frac{22}{21}$ \\
\hline Per bushel & -11 & cents per bushel & \\
\hline Gross returns & 69 & 75 & 70 \\
\hline Costs & 74 & 68 & 64 \\
\hline Net returns & -5 & 7 & 6 \\
\hline Distribution of trees according to age & & percentage of total & \\
\hline & percent & percent & percent \\
\hline 20 years and under & 15 & 17 & 23 \\
\hline $21-30$ & 60 & 67 & 63 \\
\hline 31 years and over and unclassified & 25 & 16 & 14 \\
\hline Distribution according to variety & & percentage of total & \\
\hline York & percent & percent & percent \\
\hline $\begin{array}{l}\text { York } \\
\text { Stayman }\end{array}$ & 29 & 23 & 10 \\
\hline $\begin{array}{l}\text { Stayman } \\
\text { Delicious }\end{array}$ & 14 & 15 & 19 \\
\hline $\begin{array}{l}\text { Delicious } \\
\text { Grimes }\end{array}$ & 9 & $\begin{array}{r}12 \\
9\end{array}$ & 22 \\
\hline Jonathan & 7 & $\begin{array}{r}9 \\
12\end{array}$ & 13 \\
\hline Rome & $\frac{4}{5}$ & $\begin{array}{r}12 \\
5\end{array}$ & 6 \\
\hline Other & $\begin{array}{r}5 \\
32\end{array}$ & $\begin{array}{r}5 \\
24\end{array}$ & 7 \\
\hline Spray material costs & 32 & dollars per acre & 23 \\
\hline Material & 10.99 & 12.45 & 15.06 \\
\hline Labor & 5.25 & 5.72 & 6.68 \\
\hline $\begin{array}{c}\text { Total: per acre } \\
\text { per tree }\end{array}$ & $\begin{array}{r}16.24 \\
0.48\end{array}$ & $\begin{array}{r}18.17 \\
0.40\end{array}$ & $\begin{array}{r}21.74 \\
0.36\end{array}$ \\
\hline
\end{tabular}

"The term "per acre of bearing fruit" is used to describe the orchard as set. 


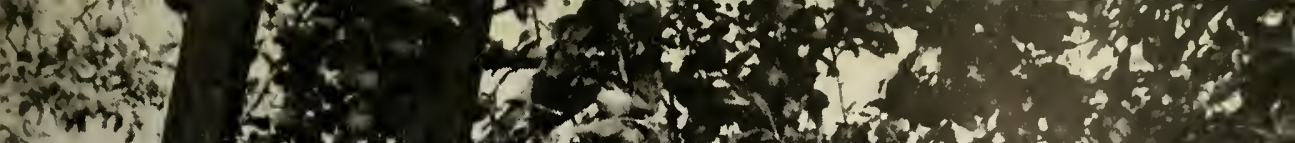

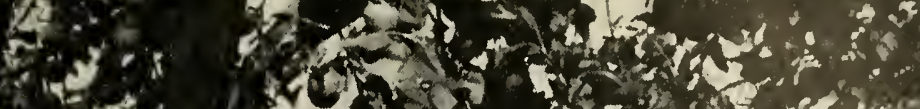

순

o. B -

$y^{4}-1,1$

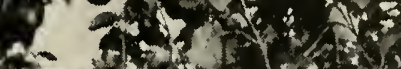

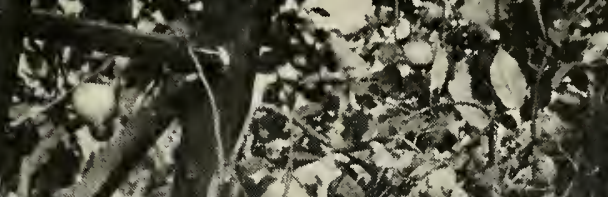

I.

$2 \times$

.

(2.

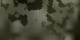

6

24

1.6.

1.6.

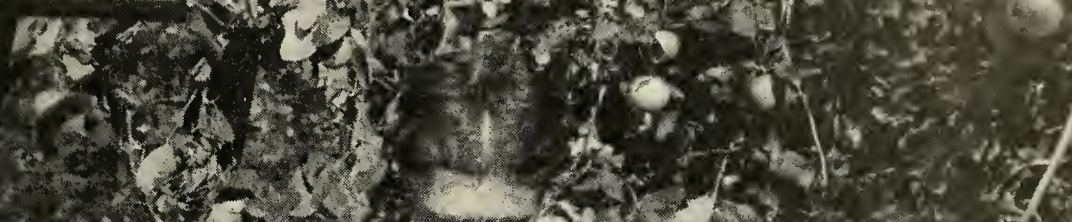
S.

(2)

,

द्धार

5

414. 35

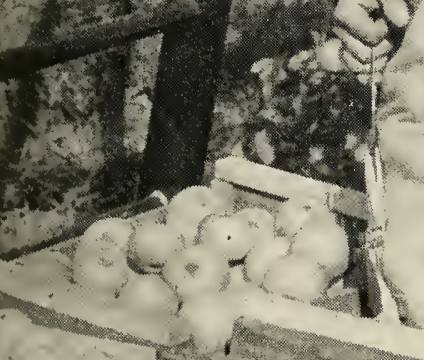

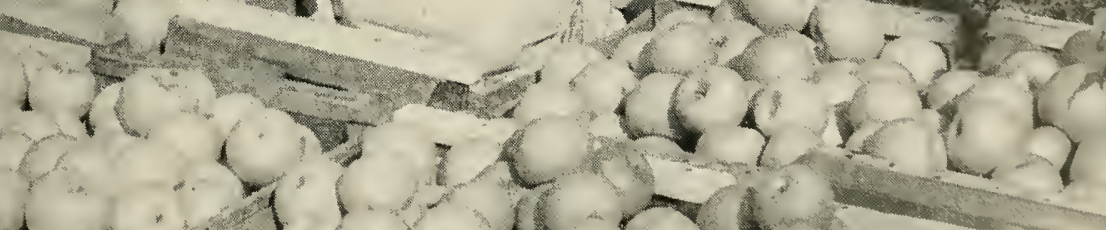

18.

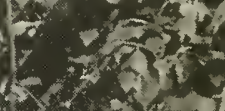

in

a. $1: 14$

1.37

to

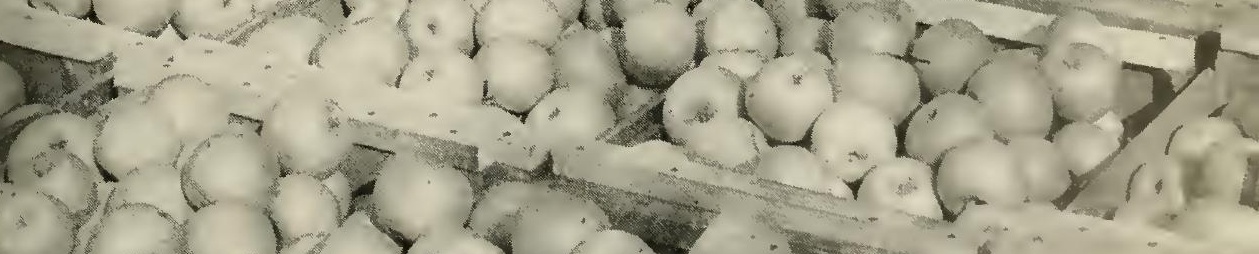

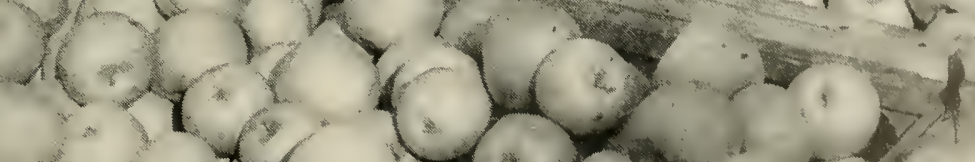


Distribution of trees according to age groups indicated that there were fewer producing trees in the 11-20-year age group in the classification having the least trees per acre. Likewise there was a tendency for these same orchards to have a greater proportion of trees in the old- and uncertain-age groups. It is evident that the larger proportion of old trees for orchards having 40 trees or less per acre might account for a lower proportion of packed fruit because of the natural tendency of old trees to produce smaller apples and to be more difficult to spray effectively. It is doubtful, however, if there was enough difference in the age of trees to have a significant bearing on yields in the various groups. The proportion of trees in the less-than-40-trees-per-acre class that were in the most productive age group (21-30 years) differed but little from that reported for other classes.

Differences also were found in the distribution of varieties according to classification based on the number of trees per acre of bearing fruit. For instance those orchards having 50 trees or more per acre had an unusually high proportion of Grimes, Stayman, and Delicious trees and a relatively low proportion of Yorks. In fact this group reported that but 10.7 percent of all trees were Yorks as compared with 29.1 percent for the orchards having less than 40 trees per acre (Table 19). Distribution of varieties, therefore, was of some significance in influencing the proportion of fruit packed and in contributing to differences in total yields.

\section{Marketing Practices}

Some of the more important marketing considerations that have a bearing on possibilities for profitable orchard operation are considered in this section. While only general aspects of these factors will receive attention, they have sufficient influence on the profits and losses experienced from year to year to deserve the careful thought of apple growers. Special attention is given to the following items as they relate to marketing practices: (1) the role of local apple storages, (2) methods of sale, and (3) the growing complexity of marketing problems.

The Role of Local Apple Storages: One of the significant developments pertaining to apple storage has been the establishment of a number of locally operated refrigerated storages in the Eastern Panhandle of West Virginia. Most of these storages are operated by individual growers, although two cooperative storages have been organized in recent years. Nearly half the commercial fruit stored in West Virginia is handled in these storages located within the producing area. A previous study has shown that the principal advantages of these storages include (1) increased control over fruit at time of harvest, (2) greater efficiency in packing combined with the advantage of selling "fresh packed" fruit, (3) increased control over the marketing of fruit with greater possibilities for developing better market outlets, and (4) greater net returns to operators. ${ }^{20}$

It is evident that these possible advantages have such direct bearing on orchard operation that they merit the careful attention of growers. To the extent that the ownership of their own storages may prompt some growers to market their own apples, it is important for them to realize that the problems

${ }^{20}$ David Volkin and M. A. Abrahamsen, Refrigerated Storage Plants in the Eastern I'anhandle of West Virginia, W. Va. Agr. Expt. Sta. Mim. Cir. No. 43. Dec. 1940. 
of marketing are many and varied. In such a new role they would be undertaking to perform functions that previously were handled by established market agencies. Consequently they must be prepared to do a better job than these agencies if they are to realize greater returns. It is very important that orchardists recognize the implications of their changed position should they undertake to market their own fruit.

If growers are to reap the benefits and avoid the possibilities of disastrous loss in the operation of local storages, it seems essential that they recognize that successful local operation depends upon a number of factors: (1) ability to master all engineering problems that may arise incidental to local storage operation; (2) ability to organize packing operations so as to coordinate them with the efficient performance of the storage function; $(3)$ ability to find better markets for cull fruit; (4) ability to maintain or find good outlets for quality fruit; and (5) ability to recognize the influence on prices obtained of such factors as trends in production, consumer purchasing power, and foreign demand. Growers must then adjust their storage operations to meet the changes these factors may set in motion.

Methods of Sale: Some indication of the types of buying agencies serving growers in the Eastern Panhandle of West Virginia may be seen from data in Table 20. While it is recognized that conditions may vary as to the proportion of yearly production taken by different agencies, there is little basis for concluding that new or different types of agencies have become significantly important in handling apples during the past decade. Apples usually are sold on a commission basis; commissions are expressed as a percentage of net returns before deducting commissions (generally 6 to 10 percent). In other instances a flat commission is charged (of ten 10 cents per bushel). Local buyers purchase fruit in a wide variety of ways. Some buy packed fruit, others purchase it packed according to their specifications, and still others purchase "tree run" apples.

In 1937 three agencies (commission men, local buyers, and processors) accounted for four-fifths of all apples sold. Truckers accounted for an additional one-twelfth; the rest were sold to or through chain and local stores, roadside markets, exporters, agencies of government, and similar outlets.

TABLE 20-Distribution of Apple Sales as Reported for 25 Growers in the Eastern Panhandle of West Virginia, 1937

\begin{tabular}{lrr}
\hline \multicolumn{1}{c}{ Buying agency } & Production & Percentage of total \\
\hline Terminal commission agencies & bushels & 31.6 \\
Local buyers & 88,306 & 28.9 \\
Processors & 81,012 & 19.5 \\
Truckers & 54,538 & 8.6 \\
Chain stores & 23,977 & 3.7 \\
Exporters & 10,420 & 2.7 \\
Roadside markets & 7,500 & 2.4 \\
Other & 6,850 & 2.6 \\
& 7,310 & 100.0 \\
\hline
\end{tabular}

Considerable difference prevailed in the market outlets used by different kinds of growers. There was a tendency for the larger commercial operators to avail themselves of the services of commission men (either local or central market) or to sell direct to wholesale divisions of chain stores. Many of the smaller operators, either because of poorer quality of apples or limited pro- 
duction facilities, utilized such outlets as processors and truckers rather extensively. It also was a common practice for the smaller growers to sell a considerable portion of apples direct to local buyers. While some of this fruit found its way to central wholesale markets, as a rule it was sold direct to jobbers and special retail outlets.

The larger commercial operators reported packing twice as many apples as the smaller ones. They, however, sold only one-third as many apples by tree run as did the smaller orchardists. Classification of fruit at time of sale was reported by 26 growers as follows:

$\begin{array}{lc}\begin{array}{c}\text { Classification at time } \\ \text { of sale }\end{array} & \begin{array}{c}\text { Percentage of total } \\ \text { percent }\end{array} \\ \text { Packed } & 54 \\ \text { Tree run } & 14 \\ \text { Processors and unclassified } & 32\end{array}$

One cooperative-sales agency operates in the territory served. In addition numerous packing sheds are operated on a community basis. In a few instances the larger growers operated their own sales agencies. ${ }^{21}$ In addition to handling their own sales, they at times served a limited number of individual growers on a commercial basis. As a rule they dealt directly with centralmarket representatives.

The Growing Complexity of Problems of Marketing: It is not known whether growers will tend to do more of their own marketing in the future or whether they will continue to rely on established marketing agencies for the sale of their apples. In any event it will be to their advantage to take further steps to acquaint themselves with the various considerations that have a bearing on the successful marketing of apples. It is only by so doing that they are in position adequately to perform this function themselves or to evaluate the performance of the sales agency serving them. The past experience of many growers, however, has not been too successful in venturing into the market place with a seasonal crop such as apples.

To be successful in marketing, some of the more important factors that they will have to consider include (1) knowledge of changes in the freight-rate structure and its influence on ability to sell advantageously at selected markets, (2) influence of trucking as a modifying factor in determining sales methods and market outlets, (3) understanding modern trends in packaging. (4) significance of and likely trends in competition from other fruits, (5) consumer preference for varieties, and (6) ability to analyze demand and price relations. All these need the careful attention of growers if they are to assurc themselves of success in the performance of marketing functions.

Other and very real difficulties exist as to problems associated with the distribution of apples through established market channels. Questions arisc from time to time as to the efficiency of many of the central-market distributive agencies that sell apples as well as other farm products. This criticism may be more vocal than ever, since these agencies resist reductions in the "wind-fall"

\footnotetext{
${ }^{21}$ Local commission agencies usually pass on to growers central-market brokerage fees which are charged when they use agencies because of inability to make a sale through their established outlets. It is submitted that this is an unfair practice. In actual practice it simply means that, at the very time he can stand it least, the grower gets an "extra sock" while the sales agency assumes no responsibility for its failure to make a sale. It is situations such as these that have prompterl some producers to develop their own sales outlets.
} 
margins that have prevailed during wartime. There is little doubt that, if many of these apple distributors really needed the margins that prevailed during wartime, it is a tacit admission of inefficiency in the operation of the present marketing machinery so monumental as to warrant the immediate and careful attention of producers in the post-war era.

\section{The Role of Management}

It has been indicated that management is one of the more intangible factors having a bearing on the extent of profits realized from apple production. As such it is less subject to quantitative measurements than are many of the other factors associated with successful orchard operation. This section gives attention to (1) selected operating practices showing the influence of management, (2) use of labor and capital resources, and (3) characteristics of management that contribute to success.

\section{Selected Operating Practices Showing the Influence of Management:} The influence of management may be indicated by performance in carrying out certain selected operations. Relationship of codling-moth infestation to spray-material costs and comparison of orchard performance under absentee and resident ownership are used here to bring to the foreground ways in which management may make significant contributions to profitable orcharding.

Information presented in Table 21 indicates the relationship of infestation from codling moth to expenditures for spray material and spray labor. The higher elevation of mountain orchards and the tendency for trees so situated to be smaller are major factors in accounting for less codling-moth damage on these orchards and explain the lower costs for spray material and labor on these orchards. It is significant that in valley orchards, irrespective of the proportion of apples showing worm damage, rather uniform costs prevailed on most orchards for the spraying operation.

Valley growers producing the wormiest apples (53 percent infestation) had per-acre expenditures of $\$ 16.72$ for spray material as compared with $\$ 14.13$ for those having the least worms (19 percent infestation). Total per-

TABLE 21-Relationship of Codling-moth Infestation to Spray-material and Spraylabor Expenditures as Reported for 24 Orchards in the Eastern

Panhandle of West Virginia, 1940-1941 ${ }^{1}$

\begin{tabular}{|c|c|c|c|c|}
\hline \multirow[b]{2}{*}{ Item } & \multirow{2}{*}{$\left|\begin{array}{c}\text { Mountain } \\
\text { orchards } \\
\text { Under 12 } \\
\text { percent } \\
\text { affected } \\
\text { apples }\end{array}\right|$} & \multicolumn{3}{|c|}{ Valley orchards } \\
\hline & & $\begin{array}{c}\text { Under } 25 \\
\text { percent } \\
\text { affected } \\
\text { apples }\end{array}$ & $\begin{array}{c}25-40 \\
\text { percent } \\
\text { affected } \\
\text { apples }\end{array}$ & $\begin{array}{c}\text { Over } 40 \\
\text { percent } \\
\text { affected } \\
\text { apples }\end{array}$ \\
\hline Number of orchards & 5 & 7 & 6 & 6 \\
\hline Proportion of apples affected (percent) & 9 & 19 & 30 & 53 \\
\hline Yield per acre (bushels) & 248 & 297 & 316 & 250 \\
\hline Proportion of apples packed (percent) & 69 & 54 & 44 & 48 \\
\hline Spray costs per acre & & dolla & cre & \\
\hline Material & 9.98 & 14.13 & 14.24 & 16.72 \\
\hline Labor & 7.15 & $\begin{array}{r}14.10 \\
6.69\end{array}$ & $\begin{array}{r}14.24 \\
4.26\end{array}$ & 5.76 \\
\hline Total & 17.13 & 20.82 & 18.50 & $22.4 \mathrm{~S}$ \\
\hline
\end{tabular}

${ }^{1}$ Information relating to the degree of apple infestation from codling moth was reported for 1941 by Professors C. F. Taylor and R. S. Marsh, Departments of Plant Pathology and Horticulture, respectively. Orchard infestation was determined on samples collected from five York and five Stayman trees selected at random. From each of those trees $10 \mathrm{fruits}$ were picked at random from the top and 10 were picked from ground level. 
acre costs for material and labor for these classes of farms were, respectively, $\$ 22.48$ and $\$ 20.82$. It is interesting to note the performance of three orchards situated on limestone soil that had the lowest infestation on this type of soil. They had an average per-acre yield of 360 bushels per acre, pack-out of 63 percent, and codling-moth infestation of 15 percent. Spray material costs were $\$ 11.34$ per acre and spray labor charges $\$ 6.69$ per acre. These expenses were nearly 20 percent less than those incurred by growers reporting the wormiest apples. In general it seems that the most effective codling-moth control is obtained when labor for spraying constitutes a relatively high proportion of total spray costs ( $T$ able 21 ). It is possible, of course, that prevailing conditions as to infestation are the result of control practices that, to a large extent, were or were not followed during preceding years.

Comparison of apple infestation on orchards of absentee and resident owners also offers significant information as to spray costs and degree of infestation. These comparisons were reported as follows:

Codling-moth infestation-percentage of apples affected

Spray costs

Material

Type of ownership
Absentee

Comparisons

11

12

36

18

Labor

14.28

dollars per acre

5.19

14.10

Total

19.47

7.15

21.25

The preceding discussion suggests that inability to obtain reasonable codling-moth control usually cannot be traced to failure to make adequate expenditures for spray material. It seems rather that good control is primarily a matter of proper timing of sprays, use of good equipment, following approved methods of thorough application, selection of proved spray materials for the job to be performed, and employment of competent labor. Ability to make correct decisions in these matters is an indication of the qualifications of management in carrying out good orchard operations.

Of further interest is a comparison of orchard operations and costs and returns from apple production as reported by absentee and resident owners. These comparisons were as follows:

Comparison

Number of orchards

Production-bushels per acre

Percentage packed-percent

Costs and returns

Gross returns

Costs

Net returns

Type of ownership:

\section{Absentee}

25

169

52

\begin{tabular}{ccccc} 
& \multicolumn{2}{c}{ per: } & \multicolumn{2}{c}{ per: } \\
Costs and returns & acre & bushel & acre & bushel \\
Gross returns & dollars & cents & dollars & cents \\
Costs & 115 & 68 & 271 & 74 \\
Net returns & 133 & 79 & 231 & 63 \\
\hline
\end{tabular}

Resident

20

368

59

Before considering the preceding data a word of caution may be in order. The fact that certain orchards are currently in the absentee ownership classification seems to be to a large extent the result of past circumstances. Therefore performance may be more of a reflection of conditions that prevailed pre- 
viously than an adequate measure of the ability of present ownership. For instance, it is an established fact that as some of the orchards shifted from resident to absentee ownership they were characterized by (1) sales at highly inflated values with a consequent overburdening debt load, (2) purchase by a class of persons who had relatively little experience in orcharding, and (3) in some instances, loss of orchards by owners with an intermittent period of "bank ownership."

It is significant that resident-owned apple orchards had yields of 368 bushels per acre-over twice that of absentee-owned orchards - and that they averaged 59 percent of all fruit packed as compared with 52 percent for absentec-operated orchards. These facts are important in explaining why the former had net returns of $\$ 40$ per acre or 11 cents per bushel, while the latter had losses of $\$ 18$ per acre or 11 cents per bushel. The specialized character of apple production and the need of entrusting operations to persons in position to exercise sound judgment indicate that very close control needs to be exercised over operations. The number of orchard managers on absentee-owned orchards who have this ability is too small for best long-time interests of the apple industry in the Eastern Panhandle of the state.

Use of Labor and Capital Resources: One test of competent management is its ability to use effectively the labor and capital resources at its disposal. This applies to owners operating their own holdings as well as to hired managers on absentee-owned orchards.

Since wages and salaries for labor and management comprised from onethird to two-fif ths of all orchard expense, it is imperative that careful plans be developed for their efficient use. One of the foremost problems of management involves selection and maintenance of competent laborers suited to the tasks they have to perform. To use labor effectively calls for careful planning of dayto-day operations. Therefore management has to know what tasks need to be performed and how they should be undertaken. It is important also that management recognize the needs of employees and that the door be left open for all those showing ability and initiative to progress accordingly.

Equally essential in the successful operation of an orchard is the ability of management to make effective use of its capital resources. In actual orchard operation this has many practical applications and raises a number of questions, foremost of which are: Should new orchard plantings be made? Should additional labor or new equipment be used to perform certain jobs? Would it be advantageous for a grower to build his own storage? What type of equipment is needed effectively to operate the orchard enterprise? What plans should be made for the supervision of working capital?

Regarding supplies and equipment, equally important problems arise. Management must decide how much of various supply and equipment items should be purchased, the quality of such products needed for effective operation, the most satisfactory time and place for obtaining them, and the most advantageous methods of procurement.

The nature of these questions is enough to indicate that very real ability is needed if management is to make sound decisions in the use of labor and capital resources. Such ability is not usually found in a manager who was paid $\$ 100$ per month during $1938-1941$. Neither was ability to carry out managerial decisions in good hands when entrusted to employees receiving but a dollar a 
day during this period. This may be just another instance in which "cheap help" proves extremcly costly when measured in terms of the results obtained. ${ }^{22}$

Characteristics of Management Contributing to Successful Orchard Operation: Except for acquaintanceship with the many technical details of orchard operation, the characteristics of a good orchard manager are not unlike those required for most business enterprises.$^{23}$ Certainly in the selection (f a manager it is important for owners to consider such general characteristics as (1) general farm and orchard experience, training, and education; (2) family health; (3) family interest and cooperation in work; (4) ambition as evidenced by ability to get work done; and (5) ability to handle labor and use capital effectively. Along more general lines the following factors seem important as indications of progressive management: (1) interest in farm papers and acquaintanceship with topics of general agricultural interest; (2) inclination and ability to use agricultural-outlook information; (3) knowledge of the findings and recommendations of colleges of agriculture; (4) acquaintanceship with county agents, Extension workers, and representatives of various Federal action agencies; and (5) a sense of public spirit.

The following illustrations serve to emphasize the importance of the role played by management. For instance, two orchards may have almost identical spray costs per acre. One, however, because of such factors as recognition of the importance of having good equipment and maintaining it in good repair, intelligent selection of materials well suited to needs, and careful timing of operations may be able to produce fruit that packs 75 percent U. S. No. 1 or better. Another with makeshift equipment, poor selection of material and ingredients (often purchased because of persuasive argument of agents rather than proved performance), and inability to apply the spray in a timely and thorough manner may not be able to produce over half as much fruit of comparable quality. Similarly, equal expenditures in pruning may produce results that vary all the way from the development of a valuable commercial orchard capable of producing quality fruit to a situation where misshapen and poorly developed trees contribute to high spraying and picking expense, poorquality fruit, and low yields.

${ }^{22}$ In this connection it is interesting to note that in reading this publication in preliminary form one of the progressive growers in the state submitted the following comments:

“... We believe that the worst trouble with most orchard operations in West Virginia is that they are sorely undermanaged.

". . I can think of many growers who are trying to do a $\$ 50,000$ or $\$ 100,000$ annual business with a $\$ 100$-per-month manager.

"Most orchard managers in this area are poorly equipped educationally to assume their great responsibilities. The low salaries paid and relatively poor working conditions have much to do with this. Young men, properly educated, are not inclined to go into work that pays so little and has practically no future.

"It seems to me that what we need here in Eastern West Virginia is less $\$ 100$ managers and more $\$ 4,000$ or $\$ 5,000$ men. We know of no industry of the size and importance of ours so poorly managed ..."

${ }^{23}$ Professor R. H. Sudds of the Department of Horticulture, West Virginia University, lists the following as indications of good "orchard mentality:" (1) selection of a site that is frost-free, accessible, protected from wind, relatively free from hail damage, and possessing good air drainage; (2) selection of soil that has "good" depth, lends itself to erosion control, and is properly managed with respect to fertilizer application and the growth of cover crops or sods; (3) adoption of a planting plan that fits the site advantageously and gives consideration to distances between trees and crowns; (4) development of pruning practices that eliminate "poor" wood, weak trees, sick trees, and unprofitable varieties-this to be combined with efforts designed to shape trees, avoid breakage, and permit necessary cultural practices with a maximum of convenience; (5) effective disease, insect, and rodent control; and (6) followed by harvesting operations that give full recognition to the importance of such operations as picking, packing, sizing, grading, and storing. It is the integration of all these factors which makes any orchard operation successful or otherwise." (Personal communication.) 


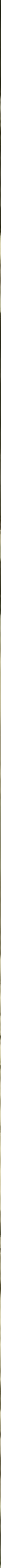


The preceding discussions of (a) costs and returns from apple production, (b) significant features of selected orchards, and (c) factors contributing to profitable orchard production indicate that the following factors are important considerations in maintaining profitable operation:

1. First and foremost, high yields per acre-25 percent or more above the average reported in this study-are a "must" if most operations are to be successful.

2. Extensive inputs of productive factors for the orchard business were evidenced by the use of large amounts of such productive resources as labor, operating equipment, and other forms of capital. As a general rule these inputs were evidenced by high per-acre costs. Since profitable orchards have high production, these costs, however, were low when expressed on a per-bushel basis. In actual practice, per-acre costs were high because increased production resulted in higher harvesting and marketing expenditures. Likewise, the necessity of making extensive outlays for productive purposes and for numerous overhead items indicates that, while reductions may be possible for individual orchards, the likelihood that these expenditures can be reduced on an over-all basis is rather remote. In contrast, per-bushel costs are low because production and overhead costs tend to vary indirectly with yield.

3. Such factors as soil series, varieties of apples grown, and age of trees are important in contributing to increased yield; together with sales arrangements they account for increased returns. While important on individual orchards in explaining good or poor performance, these factors did not maintain their identity when "averages" were used to describe the performance of groups of profitable and unprofitable orchards.

4 Observations of this study indicate that the importance of competent management is a factor that deserves further consideration as an item contributing to profitable orchard operation.

\section{ORCHARD-DEVELOPMENT COSTS AND DEPRECIATION}

The cost of developing a bearing apple orchard, together with depreciation charges, once an orchard has reached a state of productivity, are items that usually have not received full consideration in orchard-management studies. Many growers do not differentiate between expenses associated with orchard development and those incurred in the production of bearing fruit. The expenses reported, therefore, of ten are far from representing the true costs of producing apples because they also may include the many items involved in maintaining or developing productive orchards. For this same reason growers have discovered that bank balances are extremely poor criteria for measuring profitableness of year-to-year operations. This is especially true because these balances may be depleted while valuable new orchards are being developed or because they may accumulate even though investments in productive orchard resources are not maintained. In this discussion, as applied to apple orchards, attention is given to (1) development costs, (2) depreciation charges, and (3) the "production unit" method of depreciation.

\section{Development Costs}

It has been suggested that, depending upon whether an orchard is classified as bearing or nonbearing, various expense items should be handled in different ways. Until an orchard reaches bearing age, the costs incurred in its 
development represent additions to capital investment and as such ought to be segregated from the costs of producing apples. After an apple orchard comes into production, expenses incurred in operations become strictly the costs of apple production.

This distinction between costs as they apply to orchard development and to apple production is very important. Development costs should be kept segregated in order that the amount of the item may be known and so that depreciation may be charged accordingly. This practice also has the advantage of maintaining accounts for income-tax purposes as well as for obtaining more accurate information as to the true nature of production costs. ${ }^{24}$

Information relating to the costs involved in bringing an apple orchard into bearing age is presented in Table 22. The three orchards for which satisfactory information as to development costs was available represent three widely varying types of operation. Orchard No. 1 is a typical family type of establishment. It is characterized by efficient operation, but, because the unit is relatively small, investments in buildings are rather high. Orchard No. 2 is a large corporation holding which will be devoted exclusively to apple production. High material and equipment costs and low overhead in buildings characterize this operation. Orchard No. 3 also is a corporate operation. Utilization of equipment and buildings on other orchards, however, is among its advantages and helps to account for relatively low costs in bringing it into bearing. General farming operations also are being run in conjunction with this orchard.

Further examination of data presented in Table 22 indicates that, under varying conditions prevailing in the decade of the 40's, growers are likely to have an investment of $\$ 250$ to $\$ 400$ in each acre of apples brought into bearing. This does not include the value of bare land, estimated at $\$ 35$ to $\$ 75$ per acre.

Development costs include land preparation and tree expense; labor, equipment, and material; expenditures for such jobs as pruning, fertilizing, cultivating, spraying, and rodent control; all other cash expenses relating to orchard development; and such overhead items as interest on investment (land, orchard, equipment, and buildings), building and machinery repairs, taxes, insurance, and administration.

Slightly over two-thirds of all expenditures for orchard development are of such a nature as to qualify as an expense for the calculation of depreciation costs as recognized by the Bureau of Internal Revenue. ${ }^{25}$ The remaining onethird represents interest on investment in land, buildings, equipment, and

\footnotetext{
${ }^{24}$ General observation with respect to the use of cost data may be in order. In light of records kept by numerous apple growers, indications are that orchard development and production eosts could be separated without requiring marked changes in accounting procedure or necessitating the collection of much additional information. What is more, such shortcomings as were eommon in accounting practices often relate to failure on the part of the operator to use available information or to organize accounting practices so as to be able to use them effectively in the determination of sound operating policies with respect to production and marketing rather than to failure to obtain the necessary information. It is only when information available through business records is used to guide and evaluate operating methods that growers are justified in devoting appreciable time and effort to obtaining such records.

${ }^{25}$ This statement is based on the assumption that salary for management represents actual cash expenditures. Where management is a family proposition and involves no cash expenditure it is not recognized by the Bureau of Internal Revenue as a cost in orchard development and consequently may not be used in figuring depreciation.
} 
TABLE 22-Estimated Costs for Developing 10-year-old Orchards in the Eastern Panhandle of West Virginia ${ }^{1}$

\begin{tabular}{|c|c|c|c|c|c|}
\hline \multirow{2}{*}{ Kind of costs } & \multirow{2}{*}{\multicolumn{2}{|c|}{$\begin{array}{l}\text { Average per- } \\
\text { acre costs }\end{array}$}} & \multicolumn{3}{|c|}{$\begin{array}{l}\text { Per-acre costs for } \\
\text { selected orchards }\end{array}$} \\
\hline & & & Orchard & Orchard & Orchard \\
\hline Recognized tax items ${ }^{2}$ & dollars & percent & dollars & dollars & dollars \\
\hline Labor & 63 & 19.2 & 83 & 67 & 37 \\
\hline Materials ${ }^{3}$ & 65 & 20.0 & 50 & 105 & 41 \\
\hline \multicolumn{6}{|l|}{ Depreciation } \\
\hline Buildings (not family home) & 4 & 1.4 & 4 & 3 & 5 \\
\hline Equipment & 18 & 5.5 & 7 & 36 & 11 \\
\hline Salary for management & 50 & 15.3 & 50 & 50 & 50 \\
\hline Unclassified $^{5}$ & 31 & 9.4 & 25 & 39 & 28 \\
\hline Total & 231 & 70.8 & 219 & 300 & 172 \\
\hline \multicolumn{6}{|l|}{ Other items } \\
\hline $\begin{array}{l}\text { Depreciation on family home } \\
\text { Interest on investment ( } 5 \text { percent) }\end{array}$ & 2 & 0.6 & 6 & $\cdots$ & $\cdots$ \\
\hline Land & 39 & 11.9 & 41 & 38 & 38 \\
\hline Buildings & 13 & 4.1 & 26 & 5 & 10 \\
\hline Equipment & 6 & 1.9 & 3 & 10 & 5 \\
\hline Orchard development & 35 & 10.7 & 30 & 55 & 20 \\
\hline Total & 95 & 29.2 & 106 & 108 & 73 \\
\hline Total all items & 326 & 100.0 & 325 & 408 & 245 \\
\hline
\end{tabular}

'Since actual figures were not available for the full 10-year period, costs were prorated in those instances in which actual data were not obtainable.

2The term "recognized tax items" applies to those items recognized by the Bureau of Internal Revenue as costs that may be deducted for income-tax purposes.

${ }^{3}$ Includes fertilizer, seeds, spray material, trees, gasoline, and similar items.

'Salary for management qualifies as an item that may be added in computing costs for income-tax purposes as long as it represents an actual expenditure. On the operator's own farm where he does his own management the Bureau of Internal Revenue will not permit its use as an expense item. In all calculations in this study this item was included, however, since the cost is just as real irrespective of whether it represents actual expenditures or the un paid efforts of owners.

${ }^{5}$ Includes taxes, licenses, insurance, small tools, and other minor expenditures as well as tree removal.

other accumulated investments in the nonbearing orchards. Depreciation on the family home accounts for the other item. While it is difficult to ascertain what these interest charges should be, the fact that large sums of money are tied up for a considerable period of years, when they might be returning interest if used in other ways, suggests the equity of making a charge for the use of such funds when they are devoted to orcharding. It may be noted that expense items recognized by the Bureau of Internal Revenue averaged $\$ 231$ per acre or from two-thirds to three-fourths of total expenses involved in developing an acre of nonbearing apple orchard to a productive stage as reported by individual growers (Table 23).

It has been indicated that in actual practice there is no clearly defined time when an apple orchard changes from a nonbearing to a bearing classification. Much depends on such considerations as varieties grown, soil and climate, and cultural practices. For a period of years cultural practices and plant food materials, for instance, have contributed to both growth and the production of fruit - the primary emphasis gradually shifting from one to the other. In other words, between the ages of 8 to 15 ycars the amount of fertilizer applied is used in varying degrees for tree development (capital investment) and operating (production) costs because the trees have started bearing at the same time that they are still making vigorous growth. Strictly speaking, it also is true that nonbearing orchards might be credited with the value of fruit produced before they attain the age of 11 years. If this is done, however, 
TABLE 23-Actual Costs Reported for the Development of a 9-year Nonbearing Orchard in the Eastern Panhandle of West Virginia, 1937-1945

\begin{tabular}{|c|c|c|c|c|c|c|c|c|c|}
\hline & & & & Costs & per acre & for: & & & \\
\hline Item & 1937 & 1938 & 1939 & 1940 & 1941 & 1942 & 1943 & 1944 & 1945 \\
\hline & dollars & dollars & dollars & dollars & dollars & dollars & dollars & dollars & dollars \\
\hline Recognized tax item. & & & & & & & & & \\
\hline Labor & 9.96 & 4.40 & 2.80 & 3.60 & 6.41 & 7.98 & 12.64 & 11.75 & 11.57 \\
\hline Material & 12.22 & 1.14 & 3.33 & 1.78 & 2.01 & 4.14 & 4.21 & 4.09 & 3.83 \\
\hline $\begin{array}{l}\text { Depreciation } \\
\text { Buildings }\end{array}$ & & .50 & .49 & 49 & & & & & \\
\hline $\begin{array}{l}\text { Buildings } \\
\text { Equipment }\end{array}$ & & $\begin{array}{l}.30 \\
.37\end{array}$ & $\begin{array}{l}.49 \\
.33\end{array}$ & $\begin{array}{l}.49 \\
.30\end{array}$ & $\begin{array}{l}.48 \\
.56\end{array}$ & $\begin{array}{l}.46 \\
.77\end{array}$ & $\begin{array}{r}.45 \\
1.60\end{array}$ & $\begin{array}{r}.45 \\
1.45\end{array}$ & $\begin{array}{r}.44 \\
1.53\end{array}$ \\
\hline Salary for man- & & & & & & & & & \\
\hline agemer & 5.00 & 5.00 & 5.00 & 5.00 & 5.00 & 5.00 & 5.00 & 5.00 & 5.00 \\
\hline Unclassified & 1.96 & .57 & .49 & .87 & .96 & .56 & .56 & .94 & 1.34 \\
\hline $\begin{array}{l}\text { Total } \\
\text { Total accum- }\end{array}$ & 29.14 & 11.98 & 12.44 & 12.04 & $15: 42$ & 18.91 & 24.46 & 23.68 & 23.71 \\
\hline $\begin{array}{l}\text { lated } \\
\text { ther items }\end{array}$ & $\cdots$ & 41.12 & 53.56 & 65.60 & 81.02 & 99.93 & 124.39 & 148.07 & 171.78 \\
\hline $\begin{array}{l}\text { Depreciation on } \\
\text { home } \\
\text { Interest on } \\
\text { investment }\end{array}$ & & .63 & .62 & .61 & .59 & .58 & .57 & .55 & .54 \\
\hline Land & & 3.3 & 3.36 & 3.36 & 3.36 & 3.36 & 3.36 & 3.36 & 3.36 \\
\hline Building & & 2.79 & 2.73 & 2.68 & 2.63 & 2.57 & 2.52 & 2.47 & 2.57 \\
\hline $\begin{array}{l}\text { Equipment } \\
\text { Orchard }\end{array}$ & & .17 & .16 & .16 & .17 & .48 & .76 & .74 & .72 \\
\hline development & & 1.52 & 2.02 & 2.54 & 3.09 & 3.71 & 4.59 & 5.49 & 6.35 \\
\hline Total & & 8.47 & 8.89 & 9.35 & 9.84 & 10.70 & 11.80 & 12.61 & 13.54 \\
\hline $\begin{array}{l}\text { Total all items } \\
\text { Total all ac- } \\
\text { cumulated }\end{array}$ & 29.14 & 2045 & 21.33 & 21.39 & 25.26 & 29.61 & 36.26 & 36.29 & 37.25 \\
\hline expe & & 49.59 & 70.92 & 92.31 & 117.57 & 147.18 & 183.44 & 219.73 & 256.98 \\
\hline
\end{tabular}

they also should assume additional development charges for some years after reaching 11 years of age. On the assumption that credit for apples produced on orchards under 11 years tends to offset additional development costs for trees past this age, plantings are classified as bearing in this study when they attain that age.

Further indication of the nature of year-to-year costs involved in developing an apple orchard to bearing age may be noted in data presented in Table 23. Except for high initial costs during the first year, there has been a gradual increase in costs (particularly labor, material, and equipment items) from the second year through the last year. Yearly costs have about doubled during this period.

\section{Depreciation Charges}

Reference has been made to the fact that orchard depreciation is an expense item that has not received adequate consideration among professional workers in the field of orchard management and too of ten has been ignored by growers. Since most of the bearing orchards in West Virginia are 15 to 35 years old, it is only in exceptional instances that actual costs of orchard development are known. It is a significant item, however, and should be taken into account if an accurate determination is to be made of the profitability of longtime orchard operation. Furthermore, since the Bureau of Internal Revenue has recognized depreciation on apple trees as a charge that may be deducted in computing income-tax returns, growers should organize their accounting systems so as to take advantage of this ruling. The Internal Revenue Code defines depreciation as "a reasonable allowance for exhaustion, wear and tear of property used in trade or business, including a reasonable allowance for obso- 
lescence." It continues by stating that, at best, depreciation can be only an "estimate," but that this estimate must be "reasonable." This suggests that if growers are to claim depreciation on costs involved in orchard development as an operating expense, they would be on stronger ground if they were in position to support their claims relating to development costs for apple orchards with data such as those discussed in the preceding section.

Findings of this study as they relate to costs and returns for apple growers in the Eastern Panhandle serve to indicate the importance of tree depreciation as an expense item. On the assumption that the costs of orchard development for those holdings currently in production were $\$ 150$ per acre (admittedly a very conservative figure), the relationship of depreciation to other selected expense items is shown in Table 24. For purposes of comparison, depreciation costs also are given for five high-cost and five low-cost orchards and for orchards with assumed development costs of $\$ 200, \$ 300$, and $\$ 400$ per acre.

Further reference to Table 24 indicates that if development costs are assumed to be $\$ 150$ per acre, depreciation charges per acre for the 45 orchards included in this study were $\$ 6.78$ per year. This average also represented 62 percent of all depreciation charges, 3.8 percent of total orchard expense, and 2.6 cents per bushel of apples produced. In contrast, when development costs are assumed to be $\$ 200, \$ 300$, and $\$ 400$ per acre, depreciation charges per bushel were correspondingly higher, being 3.5, 5.3, and 7.0 cents per bushel, respectively. Expressed another way, total yearly depreciation charges for orchard development for individual orchards ranged from $\$ 400$ to $\$ 800$ per 100 acres of bearing orchard.

Enough has been said to indicate that depreciation on apple trees is an important expense item and that growers would obtain a more complete picture of operations by taking steps to determine what these costs are for their particular orchards and then charging them in the computation of their operating costs. For growers interested in giving further consideration to the problem, several methods of charging this item have been developed. Foremost among these methods are (1) revaluation, (2) straight line, (3) diminishing balance, and (4) compound interest. Space does not permit consideration of the advantages and disadvantages as applied to orcharding. The distinc-

TABLE 24-Relationship of Apple-tree Depreciation to Other Selected Expense Items for 45 Bearing Apple Orchards in the Eastern Panhandle of West Virginia, 1938-1941

\begin{tabular}{|c|c|c|c|c|}
\hline \multirow[b]{2}{*}{$\begin{array}{l}\text { Assumed orchard- } \\
\text { development costs }\end{array}$} & \multicolumn{4}{|c|}{ Yearly depreciation on apple trees } \\
\hline & $\begin{array}{l}\text { Charges } \\
\text { per acre }\end{array}$ & $\begin{array}{l}\text { As a percent- } \\
\text { age of total } \\
\text { depreciation }{ }^{1}\end{array}$ & $\mid \begin{array}{c}\text { As a percent- } \\
\text { age of total } \\
\text { orchard expense }\end{array}$ & $\begin{array}{l}\text { In terms of cents } \\
\text { per bushel of } \\
\text { apples produced }\end{array}$ \\
\hline Av. at $\$ 150$ per acre: & dollars & percent & percent & cents \\
\hline For 45 growers & 6.78 & 62.0 & 3.8 & 2.6 \\
\hline For five high-cost orchards & 6.21 & 48.2 & 2.0 & 1.4 \\
\hline For five low-cost orchards & 4.97 & 72.9 & 4.8 & 4.2 \\
\hline Av. at $\$ 200$ per acre & 9.04 & 68.5 & 5.0 & 3.5 \\
\hline Av. at $\$ 300$ per acre & 13.56 & 76.6 & 7.3 & 5.3 \\
\hline Av. at $\$ 400$ per acre & 18.08 & 81.3 & 9.5 & 7.0 \\
\hline
\end{tabular}

1Total depreciation includes depreciation on building and equipment in addition to apple trees.

On the basis of average yearly yields of 257 bushels per acre-the average for the 45 orchards studied. 
tive characteristics of apple production with appreciable concentration of production among the 20-30-year age bracket, however, serve to indicate that none of the methods of charging depreciation listed serves adequately to meet the needs of growers in this category. ${ }^{26}$

\section{The Production-unit Method of Depreciation}

Findings of this study suggest that the "production unit" method of charging orchard depreciation comes closest to meeting the needs of orchard operations. It is based on the assumption that the depreciation of a bearing orchard is a charge that can most equitably be paid for by units of fruit produced. ${ }^{27}$ In this respect it is essentially the same as charging depreciation on cars or trucks on a mileage basis. To use this method it is necessary to have basic information concerning the production of fruit according to the age of trees. Having this information, and then assuming that depreciation is a charge that should be met during the productive life of the trees, it is possible to work out a formula that may be used in determining the amount of depreciation to charge per year.

Basic production data for the use of this method of depreciation are given in Table 25. It may be noted that production averaged 56 bushels per acre for bearing trees in the "under 16 " age group, increased to 172 bushels per acre for the period of peak production (21-25 years), and declined to 133 bushels per acre for the 31-35-year age group. By determining total production for the assumed life of an orchard it is then possible to determine the percentage of this production that comes within each 5 -year age interval. To illustrate: The 280 bushels produced by trees under 16 years of age ( 56 bushels per acre for five years-11-15-year-old trees) represent about 17.5 percent of total production for trees that produce until they are 25 years old, 12.5 percent for trees kept until they are 30 years old, 10 percent for trees that cease production when they are 35 years old, and 7.5 percent on trees that produce until they are 40 years of age (Table 25).

Data in Table 26 may be used as a formula for enabling growers to make depreciation charges according to conditions prevailing on their own orchard. Irrespective of whether orchard development costs might be $\$ 100$ or $\$ 500$ per acre, the percentage figures given may serve as a guide in charging depreciation. Should growers feel that their production pattern is essentially different from that presented, they could use their own production data and determine the depreciation charges accordingly.

To illustrate how this method of depreciation works, it may be helpful to apply it to an assumed 50 -acre block of orchard with the following characteristics: (1) development cost $\$ 200$ per acre; (2) varieties - 25 acres of 33year-old Stayman Winesap, 15 acres of 23-year-old York Imperial, and 10 acres of 13-year-old Rome Beauty; and (3) yields-225, 300, and 125 bushels per acre, respectively. Depreciation rates as determined by reference to Table

2In a few instances growers have charged depreciation on bearing apple trees. No set procedure has been adopted, however, and methods used vary widely. Where growers have presented supporting statistical information the Bureau of Internal Revenue has accepted $\$ 7.50$ per tree as the cost of development (12 years of age) and has sanctioned the depreciation of this cost uniformly over a period of 25 years.

${ }^{2}$ In a recent letter the Bureau of Internal Revenue stated that depreciation "based on estimated production will no doubt be acceptable to the Bureau." 


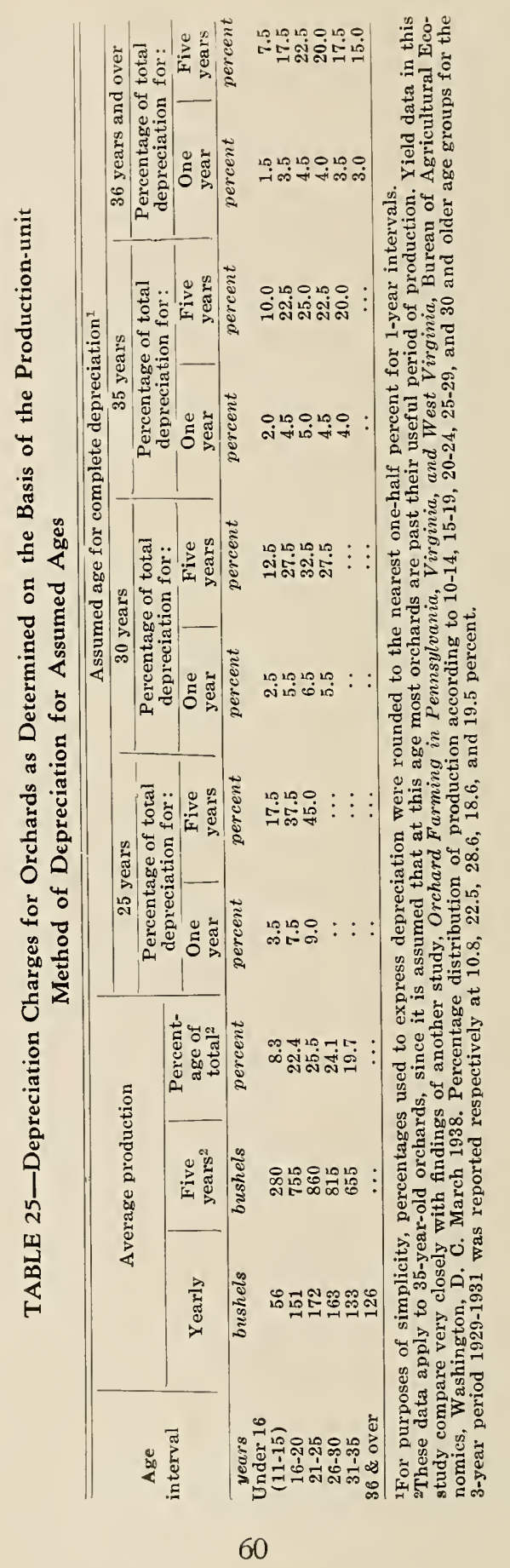



25. (assuming 35 years to be the life of these trees) were used in arriving at depreciation charges presented in Table 26).

TABLE 26-Application of the Production-unit Method of Depreciation as Applied to Plantings of Three Varieties

\begin{tabular}{|c|c|c|c|c|c|c|}
\hline \multirow{2}{*}{$\begin{array}{l}\text { Apple } \\
\text { variety }\end{array}$} & \multirow{2}{*}{$\begin{array}{l}\text { Develop- } \\
\text { ment cost } \\
\text { per acre }\end{array}$} & \multirow{2}{*}{$\begin{array}{l}\text { Deprecia- } \\
\text { tion rate }\end{array}$} & \multirow[b]{2}{*}{ Acreage } & \multicolumn{3}{|c|}{ Depreciation charges } \\
\hline & & & & Total & Per acre & Per bushel ${ }^{2}$ \\
\hline $\begin{array}{l}\text { Stayman Winesap } \\
\text { York Imperial } \\
\text { Rome Beauty }\end{array}$ & $\begin{array}{l}\text { dollars } \\
200 \\
200 \\
200\end{array}$ & $\begin{array}{c}\text { percent } \\
4.0 \\
5.0 \\
2.0\end{array}$ & $\begin{array}{c}\text { number } \\
25 \\
15 \\
10\end{array}$ & $\begin{array}{c}\text { dollars } \\
200 \\
150 \\
40\end{array}$ & $\begin{array}{c}\text { dollars } \\
8.00 \\
10.00 \\
4.00\end{array}$ & $\begin{array}{c}\text { cents } \\
3.2 \\
3.3 \\
3.2\end{array}$ \\
\hline $\begin{array}{l}\text { Total } \\
\text { Average (weighted) }\end{array}$ & $\ddot{200}$ & $\ddot{3.9}$ & $\begin{array}{l}50 \\
\cdots\end{array}$ & $\begin{array}{l}390 \\
\ldots\end{array}$ & $\dddot{7} .80$ & $\ddot{3.2}$ \\
\hline
\end{tabular}

'See Table 25.

${ }^{2}$ Average production is assumed to be 257 bushels per acre.

If yearly receipts could be substituted for production, it would be possible to introduce a refinement to the production-unit basis for charging depreciation-surely more depreciation can and should be charged off when apples sell for $\$ 3.00$ per bushel than when prices are but 75 cents per bushel. Price trends, however, are uncertain, and the best possibility for charging equitable depreciation seems to be in relating this item to production.

To summarize this discussion of apple-orchard development costs and depreciation, the following points seem significant:

(1) While depreciation on orchard equipment and buildings usually has received adequate treatment, depreciation on the orchard proper (bearing trees) has not had sufficient attention as it relates to problems of orchard development, maintenance, expense determination, and income-tax computation.

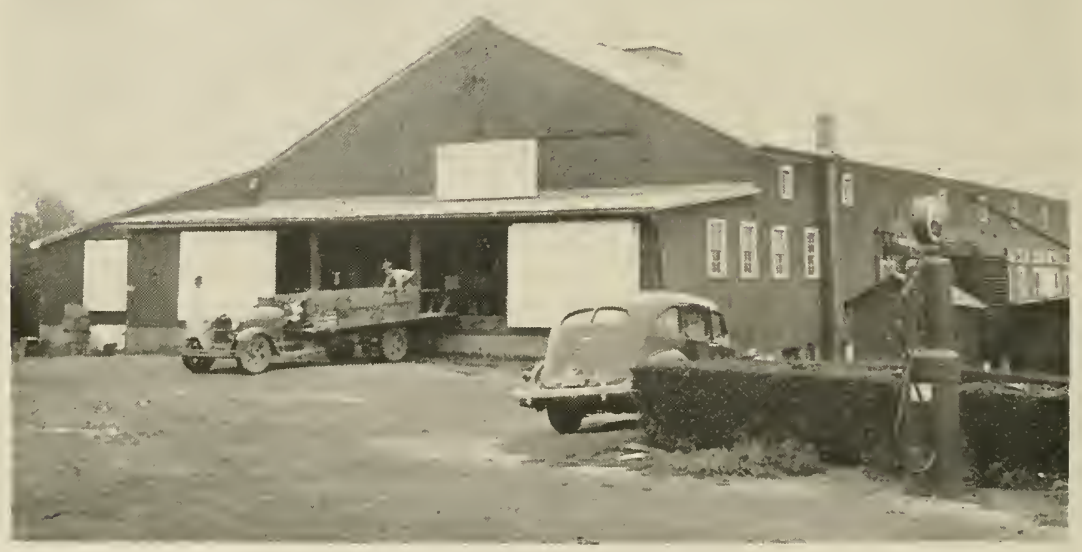

FIG. 8-Orchard Facilities

Pictured is a combination apple-packing shed, storage plant, and general utility building. Facilities of this nature explain why investments in orcharding are high 
(2) Since apple-tree depreciation is a cost that is recognized by the Bureau of Internal Revenue, it definitely is to the advantage of the growers to determine what these costs are and to organize their accounting practices so as to be able to include them in income-tax computation. Furthermore, if orcharding is to be maintained on a long-time basis, growers will have to meet costs of orchard development out of returns from production. What is more, it also is necessary if growers are to obtain an accurate picture of the profitableness of their year-to-year business operations.

(3) The development of a depreciation charge as based on the "production unit" method gives those growers who are interested in a more detailed and accurate picture of orchard depreciation an idea of how these costs can be charged to an orchard in proportion to production-the best available measure of its ability to meet these charges.

\section{SUMMARY AND CONCLUSIONS}

1. Important changes in production practices, in harvesting methods, and in marketing procedures in the apple industry suggest the need for further information regarding orchard management. This is necessary if individual growers are to have adequate guideposts for comparing performance with that of other operators and if they are to plan effectively for post-war operations.

2. Apples constitute the most important cash crop in West Virginiaaccounting for about 8 percent of the cash farm income from all sources, or 30 percent of the cash income from all crops. Commercial apple production is concentrated in the Eastern Panhandle of the state, where 85 percent of the commercial apples of the state are grown. Orcharding is a highly specialized operation and as a rule it is most important on the larger farms in the Eastern Panhandle.

3. In planning future apple production it is important that growers recognize the significance of trends within the industry. Some of the most important are:

(1) Marked reduction in the number of bearing apple trees in both West Virginia and the United States with consequent specialization in commercial apple production in especially favorable regions of the country.

(2) The close relationship of returns from apple production to consumer purchasing power suggests that apple growers have an interest in high wages, full employment, and high industrial activity.

(3) The stationary or slightly declining trend in commercial production and the decline in proportion of total farm income accounted for by apples is largely the result of the unfavorable position of apples as compared with other fresh, canned, juiced, frozen, and dried fruits-especially citrus.

(4) Foreign trade in apples has been an important factor in the apple market during the period between World Wars I and II, and indications are that these outlets again will merit the careful attention of apple producers.

4. On the 45 orchards selected for intensive study for 1938-1941 the following characteristics seem important as an indication of average performance for the period: 
(1) Average area in bearing apples per orchard-91.6 acres.

(2) Average yearly yield-257 bushels per acre.

(3) Percentage of all apples packed-57 percent.

(4) Gross returns from apples- $\$ 17,154$ per farm; $\$ 188$ per acre; $\$ 4.21$ per tree; 72 cents per bushel.

(5) Expenses for apple production-\$16,384 per farm; $\$ 179$ per acre; $\$ 4.02$ per tree; 69 cents per bushel. Production items accounted for one-fifth of total expenses, harvesting for one-third, marketing for nearly one-fifth, and overhead for one-fourth.

(6) Net returns- $\$ 791$ per farm; $\$ 9$ per acre; 19 cents per tree; and 3.3 cents per bushel.

(7) Total investments- $\$ 20,982$ per farm; $\$ 229$ per acre; $\$ 5.15$ per bearing tree; and 88 cents per bushel. Land in trees accounted for approximately one-fourth this amount, bearing trees for between one-third and two-fifths, and equipment one-seventh.

5. When speaking in terms of per-bushel costs, production costs and overhead costs were relatively fixed per acre, while harvesting and marketing costs were in direct proportion to the amount of fruit produced. When costs are expressed on a per-bushel basis, harvesting and marketing items are relatively fixed; production and overhead expense tend to vary in direct proportion to production. This emphasizes the importance of high yield as a means of reducing variable per-bushel costs.

6. Study of the 10 most profitable and the 10 least profitable orchards nd of selected orchards chosen for detailed observation indicates that a common characteristic of the more profitable orchards was high yield per acre. The importance of yield per acre is indicated by the fact that, when it was less than 200 bushels per acre, all but two orchards out of 14 had a loss from operations. In contrast, when yield was over 300 bushels per acre, only two orchards out of 15 had a loss. Those orchards in the latter group had average profits of $\$ 55$ per acre or 13 cents per bushel, while those in the former group had an average loss of $\$ 26$ per acre or 24 cents per bushel. Another significant feature of orchards with a yield of over 300 bushels per acre was the fact that they were in such favorable financial position that they had no difficulty in maintaining adequate equipment and buildings for efficient opcrations and for adequately housing employees.

This circumstance suggests the desirability of giving attention to the many factors that may be responsible for increased yield and profits. These include (a) influence of soil series, (b) relationship of size of orchard operation to profitability, (c) relationship of varieties to costs and returns, (d) certain selected operating practices, (c) marketing procedures followed, and (f) role of management.

The following obscrvations seem important regarding these factors:

(1) Consideration of the influence of soil series indicates that yield on limestone soils is appreciably higher than on shale soil ( 300 bushels per acre as compared with 172). As a rule orchards on limestone soil also were less severely eroded than those on shale soil. To counterbalance these situations, however, advantages of locations on shale soil included (a) lower investment in land, (b) lower expenditures for spraying, and (c) greater proportion of high-quality fruit. Thëse factors 
suggest, and experience has indicated, that when great care was exercised in site selection, and when management was appreciably better than average, it was possible to show very creditable performance on good shale soil, although hazards may be somewhat greater than on most limestone soils.

(2) Data obtained in this study do not substantiate the opinion that Hagerstown limestone soil has an appreciable advantage over Frankstown limestone soil. In fact, if any advantage existed it seemed to be with the Frankstown soil. Profitable operation, however, was possible on each series of soil. Similarly, unprofitable operations were as likely to occur on one as on the other. Neither do the influences of erosion show up as significantly in orchard performance as is usually thought to be the case. Statistical data indicate, however, that other factors in addition to soil or degree of erosion may account for unsatisfactory orchard performance but that chances for success are better on good soils that have experienced less erosion.

(3) Size of operation seemed to have little bearing on the ability of orchards to close their year-to-year operations at a profit. However, it was only on the larger operations that marked profits were made. It is, of course, true that the smaller orchard owners can maintain operations by reducing their own living standards to a degree that is not possible on the larger holdings, where the number of supervisors employed often was considerable.

(4) Findings of this study indicate that growers with 40 or more trees per acre of bearing apples had relatively profitable operation, while those having fewer than 40 trees usually operated at a loss. Growers reporting a large number of trees were able to maintain production per tree with no noticeable decline in quality.

(5) Marketing practices exerted considerable influence on both costs and returns from apple operations. Costs were influenced insofar as marketing practices were concerned by such factors as harvesting methods followed, types of containers used, extent of storage, and sales commission charged. Returns were influenced by kinds of sales agencies used, market outlets developed, and seasonal distribution of fruit sales.

(6) The most intangible factor in determining the possibilities of profitable apple-orchard operation was the role of management. Many of the various factors that contribute to successful management do not lend themselves to quantitative measurement. Nevertheless, the following factors seemed important: (a) practical farm experience; (b) competence as measurd by ambition to succeed, ability to get work done on time, and selection of proved methods and practices for carrying on operations; (c) ability to utilize labor resources to advantage; and (d) ability to make effective use of capital resources, giving consideration to such items as proper use of equipment, effective buying of needed supplies, and purchase at the time and place that enables operators to secure the quality desired.

7. This study indicates that the "production unit" method, a means of charging depreciation in proportion to production, seems to be the most cquitable method of accounting for this item on bearing apple trees.

8. To obtain accurate information as to costs of producing apples and expenses involved in developing producing orchards, accounting systems ld be so organized as to segregate production costs and capital investment expenses.

9. Findings of this study suggest that under existing cost relationships growers are likcly to have an investment of $\$ 250$ to $\$ 400$ in each acre of producing orchard developed in addition to the value of land. This indicates that the original capital investment necessary to establish an orchard is considerable. 


\section{APPENDIX}

TABLE A-Number of Apple Trees of Bearing Age in the United States and Proportional Distribution of Trees According to Geographic

Areas, by 10-year Intervals, 1910-1940'1

\begin{tabular}{l|c|c|cc}
\hline \multirow{2}{*}{ Year } & Bearing trees & \multicolumn{2}{|c}{$\begin{array}{c}\text { Percentage of total number of trees } \\
\text { according to geographic areas }\end{array}$} \\
\cline { 3 - 4 } & & Eastern & Central & Western \\
1910 & number & percent & percent & percent \\
1920 & $151,322,840$ & 33 & 49 & 8 \\
1930 & $115,309,165$ & 49 & 39 & 18 \\
1940 & $88,848,970$ & 46 & 40 & 15 \\
\hline
\end{tabular}

${ }^{1}$ Compiled from the United States Census of Agriculture.

TABLE B-Percentage that Apple Trees of Nonbearing age Were of Trees of Bearing Age as Reported for the United States and for Geographic Areas, by 10-year Intervals, 1910-1940 ${ }^{1}$

\begin{tabular}{l|c|c|c|c}
\hline \multirow{2}{*}{ Year } & \multicolumn{2}{|c}{ Percentage of nonbearing trees for geographic areas } \\
\cline { 2 - 4 } & United & Eastern & Central & Western \\
\hline & States & percent & percent & percent \\
1910 & 44 & 37 & 37 & 122 \\
1920 & 31 & 37 & 34 & 15 \\
1930 & 31 & 25 & 43 & 16 \\
1940 & 23 & 21 & 31 & 10 \\
\hline
\end{tabular}

${ }^{1}$ Compiled from the United States Census of Agriculture.

TABLE C-Trends in Apple Tree Numbers in West Virginia, 1910-1940

\begin{tabular}{|c|c|c|c|}
\hline \multirow[b]{2}{*}{ Year } & \multicolumn{2}{|c|}{ Trees of bearing age } & \multirow{2}{*}{$\begin{array}{c}\text { Percentage that trees of } \\
\text { nonbearing age are of } \\
\text { trees of bearing age }\end{array}$} \\
\hline & Total & $\begin{array}{l}\text { Percentage of total } \\
\text { in the Eastern area }\end{array}$ & \\
\hline $\begin{array}{l}1910 \\
1920 \\
1930 \\
1940\end{array}$ & $\begin{array}{r}\text { number } \\
4,570,948 \\
\mathbf{5 , 5 5 4 , 7 3 1} \\
5,246,817 \\
\mathbf{3}, 241,174\end{array}$ & $\begin{array}{c}\text { percent } \\
9 \\
12 \\
13 \\
12\end{array}$ & $\begin{array}{c}\text { percent } \\
61 \\
31 \\
18 \\
18\end{array}$ \\
\hline
\end{tabular}

${ }^{3}$ Compiled from the United States Census of Agriculture.

TABLE D-Trends in the Number of Bearing Apple Trees in Selected Counties of West Virginia, 1900 and $1940^{1}$

\begin{tabular}{|c|c|c|c|c|}
\hline \multirow{3}{*}{ Counties } & \multirow{2}{*}{\multicolumn{2}{|c|}{ Trees of bearing age }} & \multicolumn{2}{|c|}{ Percentage: } \\
\hline & & & \multirow{2}{*}{$\begin{array}{c}\text { That number } \\
\text { in } 1900 \mathrm{was} \\
\text { of } 1940\end{array}$} & \multirow{2}{*}{$\begin{array}{c}\text { Distribution } \\
\text { of total } \\
1940\end{array}$} \\
\hline & 1900 & 1940 & & \\
\hline & number & number & percent & percent \\
\hline Berkeley & 180,496 & 481,301 & 38 & 15 \\
\hline Hampshire & 104,712 & 277,447 & 38 & 9 \\
\hline Jefferson & 106,702 & 208,732 & 51 & 6 \\
\hline Morgan & 60,730 & 137,142 & 44 & 1 \\
\hline Mineral & 54,887 & 69,852 & 79 & 2 \\
\hline Hardy & 55,862 & 59,566 & 94 & $\bar{z}$ \\
\hline Grant & 36,602 & 13,757 & 266 & \\
\hline Others & $4,841,121$ & $1,993,377$ & 243 & $\ddot{62}$ \\
\hline Total & $5,441,112$ & $3,241,174$ & 168 & 100 \\
\hline
\end{tabular}

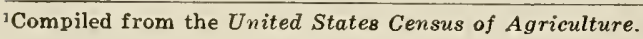


TABLE E-Apple Production, Distribution of Total Production According to Geographic Areas, and Relative Importance of Farm Income

From Apples, United States, 1910-1944

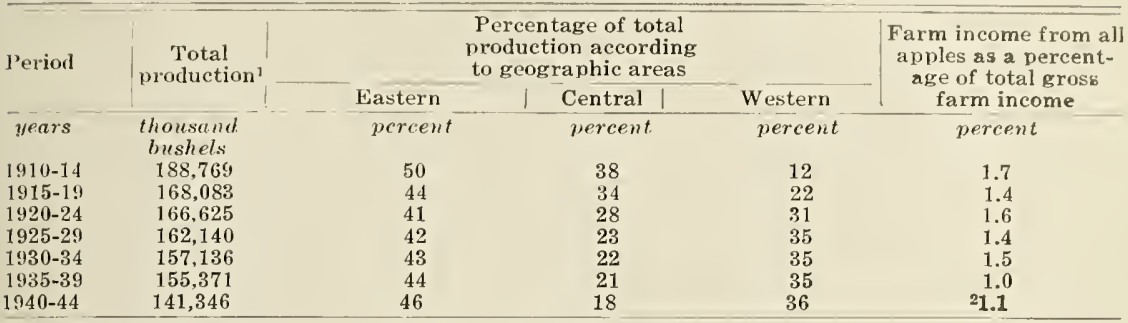

Since total production was not available after 1938, commercial production was converted to total production by assuming that it was equivalent to 81.5 percent of total production (the 1934-1938 relationship).

-1940-1943.

TABLE F-Total Consumption of Fresh Fruits, Average Yearly Per-capita Consumption, and Percentage Distribution of Total Consumption in the United States as Reported for 4-year Intervals, 1909-1944

\begin{tabular}{|c|c|c|c|c|c|c|c|c|c|c|}
\hline \multirow{3}{*}{ Period } & \multirow{2}{*}{$\begin{array}{c}\text { Total } \\
\text { consump- } \\
\text { tion }\end{array}$} & \multicolumn{9}{|c|}{ Average yearly per-capita consumption for: } \\
\hline & & All fruits & \multicolumn{2}{|c|}{ Apples } & \multicolumn{2}{|c|}{ Citrus } & \multicolumn{2}{|c|}{ Bananas } & \multicolumn{2}{|c|}{ Others } \\
\hline & Amount & Amount & Amount & $\begin{array}{l}\text { Percent- } \\
\text { age of } \\
\text { total }\end{array}$ & Amount & $\left|\begin{array}{c}\text { Percent- } \\
\text { age of } \\
\text { total }\end{array}\right|$ & Amount & $\begin{array}{c}\text { Percent- } \\
\text { age of } \\
\text { total }\end{array}$ & Amount & $\begin{array}{l}\text { Percent- } \\
\text { age of } \\
\text { total }\end{array}$ \\
\hline year & $\begin{array}{l}\text { millio } \\
\text { pound }\end{array}$ & $\begin{array}{l}\text { on pounds } \\
d s\end{array}$ & pounds & percent & pounds & percent & pounds & percent & pounds & percent \\
\hline $1909-12$ & 13,78 & 148 & 67 & 45 & 18 & 12 & 22 & 15 & 41 & 28 \\
\hline $1913-16$ & 14.80 & 148 & 66 & 45 & 21 & 14 & 20 & 13 & 41 & 28 \\
\hline $1917-20$ & 13,75 & 13 & ग0 & 4 & 2 & 1 & 1 & 1 & 37 & 28 \\
\hline $1921-24$ & 15,66 & 141 & 51 & 36 & 30 & 21 & 2 & 14 & 40 & 29 \\
\hline $1925-28$ & 17,22 & 146 & 49 & 34 & 30 & 20 & 25 & 17 & 42 & 29 \\
\hline $1929-32$ & 17,67 & 143 & 43 & 30 & 38 & 26 & 2 & 17 & 38 & 27 \\
\hline $1933-36$ & 17,16 & 135 & 39 & 29 & 42 & 31 & 2 & 15 & 34 & 25 \\
\hline $1937-40$ & 20,40 & 157 & 43 & 27 & 53 & 34 & 2 & 15 & 38 & 24 \\
\hline${ }^{1} 1941-44$ & 18,41 & 136 & 27 & 20 & 60 & 44 & 13 & 10 & 36 & 26 \\
\hline
\end{tabular}

${ }^{3}$ Preliminary. 


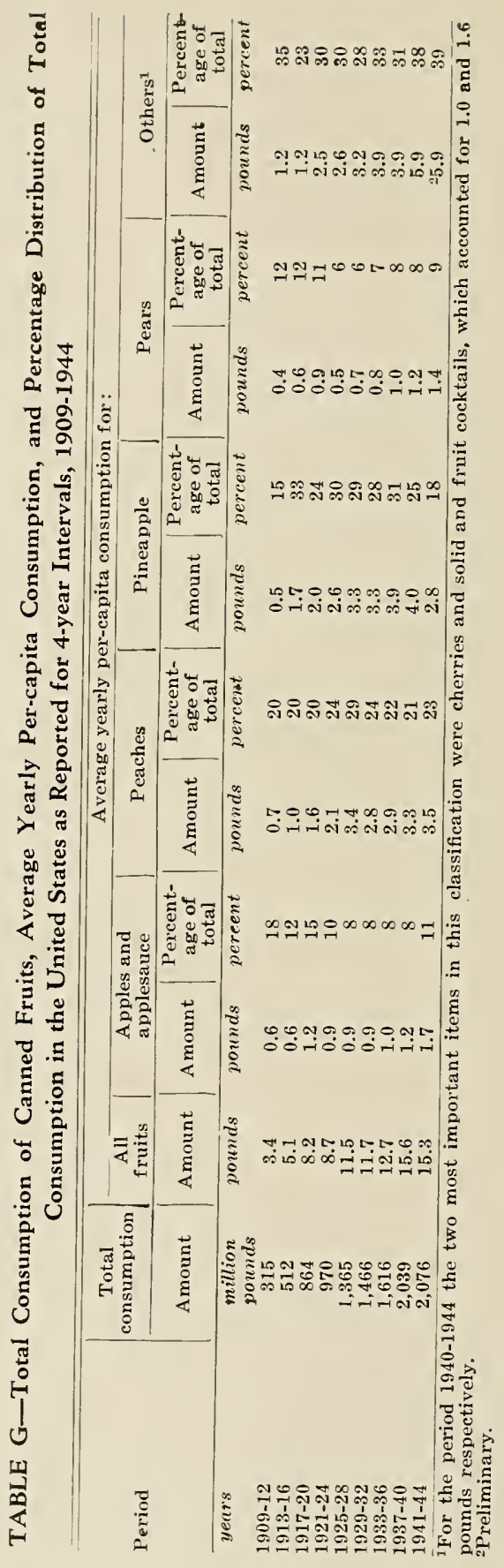


TABLE H-Total Consumption of Canned Fruit Juices and Average Yearly Per-capita Consumption as Reported for 4-year Intervals, 1909-1944

\begin{tabular}{|c|c|c|c|c|c|c|}
\hline \multirow[b]{2}{*}{ Period } & \multirow{2}{*}{$\begin{array}{c}\text { Total } \\
\text { consumption }\end{array}$} & \multicolumn{5}{|c|}{ Average yearly per-capita consumption for: } \\
\hline & & $\begin{array}{l}\text { All canned } \\
\text { fruits }\end{array}$ & Grapefruit & Oranges & Pineapple & Other ${ }^{1}$ \\
\hline years & million & pounds & pounds & pounds & pounds & pounds \\
\hline [909-12 & 30 & 0.3 & .. & 0.1 & $\cdots$ & 0.2 \\
\hline $1913-16$ & 37 & 0.4 & $\ldots$ & 0.1 & $\ldots$ & 0.3 \\
\hline $1917-20$ & 48 & 0.5 & $\ldots$ & 0.1 & . & 0.4 \\
\hline [921-24 & 40 & 0.3 & $\cdots$ & . & $\cdots$ & 0.3 \\
\hline $1925-28$ & 60 & 0.5 & 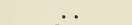 & 0.1 & $\ldots$ & 0.4 \\
\hline $1929-32$ & 137 & 0.7 & 0.1 & 0.4 & . & 0.2 \\
\hline $1933-36$ & 281 & 2.2 & 0.3 & 0.5 & 1.3 & 0.1 \\
\hline $1937-40$ & 934 & 7.1 & 2.0 & 1.3 & 2.2 & 1.6 \\
\hline $21941-44$ & 1,099 & 8.1 & 3.0 & 0.9 & 1.8 & 2.4 \\
\hline
\end{tabular}

Preliminary grape and lemon juice. Apple juice is not reported separately.

Pre'iminary.

TABLE I-Total Consumption of Dried Fruits, Average Yearly Per-capita Consumption, and Percentage Distribution of Total Consumption as Reported for 4-year Intervals, 1909-1944

\begin{tabular}{|c|c|c|c|c|c|c|c|c|c|c|}
\hline \multirow{3}{*}{ Period } & \multirow{3}{*}{$\begin{array}{c}\begin{array}{c}\text { Total } \\
\text { con- } \\
\text { sump- } \\
\text { tion }\end{array} \\
\text { Amount }\end{array}$} & \multicolumn{9}{|c|}{ Average yearly per-capita consumption for: } \\
\hline & & $\begin{array}{l}\text { All } \\
\text { dried } \\
\text { fruit }\end{array}$ & \multicolumn{2}{|c|}{ Prunes } & \multicolumn{2}{|c|}{ Raisins } & \multicolumn{2}{|c|}{ Apples } & \multicolumn{2}{|c|}{ Other } \\
\hline & & Amount & Amount & $\begin{array}{c}\text { Percent- } \\
\text { age of } \\
\text { total }\end{array}$ & Amount & $\left|\begin{array}{c}\text { Percent- } \\
\text { age of } \\
\text { total }\end{array}\right|$ & Amount & $\begin{array}{l}\text { Percent- } \\
\text { age of } \\
\text { total }\end{array}$ & Amount & $\begin{array}{l}\text { Percent- } \\
\text { age of } \\
\text { total }\end{array}$ \\
\hline years & $\begin{array}{l}\text { million } \\
\text { pounds }\end{array}$ & pounds & pounds & percent & pounds & percent & pounds & percent & pounds & percent \\
\hline $1909-12$ & 371 & 3.9 & 1.0 & 26 & 1.5 & 38 & 0.2 & 5 & 1.2 & 31 \\
\hline $1913-16$ & 436 & 4.3 & 1.0 & 23 & 1.6 & 37 & 0.3 & 7 & 1.4 & 33 \\
\hline $1917-20$ & 624 & 5.8 & 1.6 & 28 & 2.4 & 41 & 0.4 & 7 & 1.4 & 24 \\
\hline $1921-24$ & 657 & 5.9 & 1.5 & 25 & 2.7 & 46 & 0.2 & 4 & 1.5 & 25 \\
\hline $1925-28$ & 721 & 6.1 & 1.8 & 29 & 2.7 & 44 & 0.1 & 2 & 1.5 & 25 \\
\hline $1929-32$ & 642 & 5.2 & 1.7 & 33 & 2.1 & 40 & 0.1 & 2 & 1.3 & 25 \\
\hline $1933-36$ & 694 & 5.4 & 1.9 & 35 & 2.2 & 41 & 0.1 & 2 & 1.2 & 22 \\
\hline $1937-40$ & 769 & 5.8 & 1.9 & 33 & 2.4 & 41 & 0.2 & 4 & 1.3 & 22 \\
\hline${ }^{1} 1941-44$ & 692 & 5.1 & 1.8 & 35 & 2.4 & 47 & 0.1 & 2 & 0.8 & 16 \\
\hline
\end{tabular}

Preliminary.

TABLE J-Costs and Returns and Related Comparisons on a Yearly Basis as Reported for 45 Orchards in the Eastern Panhandle of West Virginia, 1938-1941

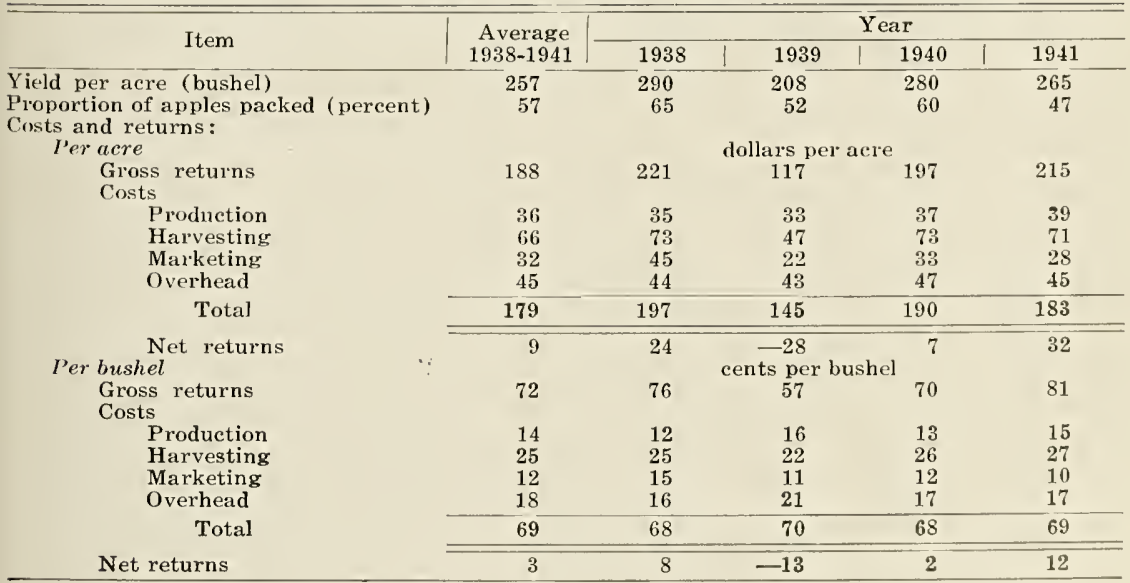




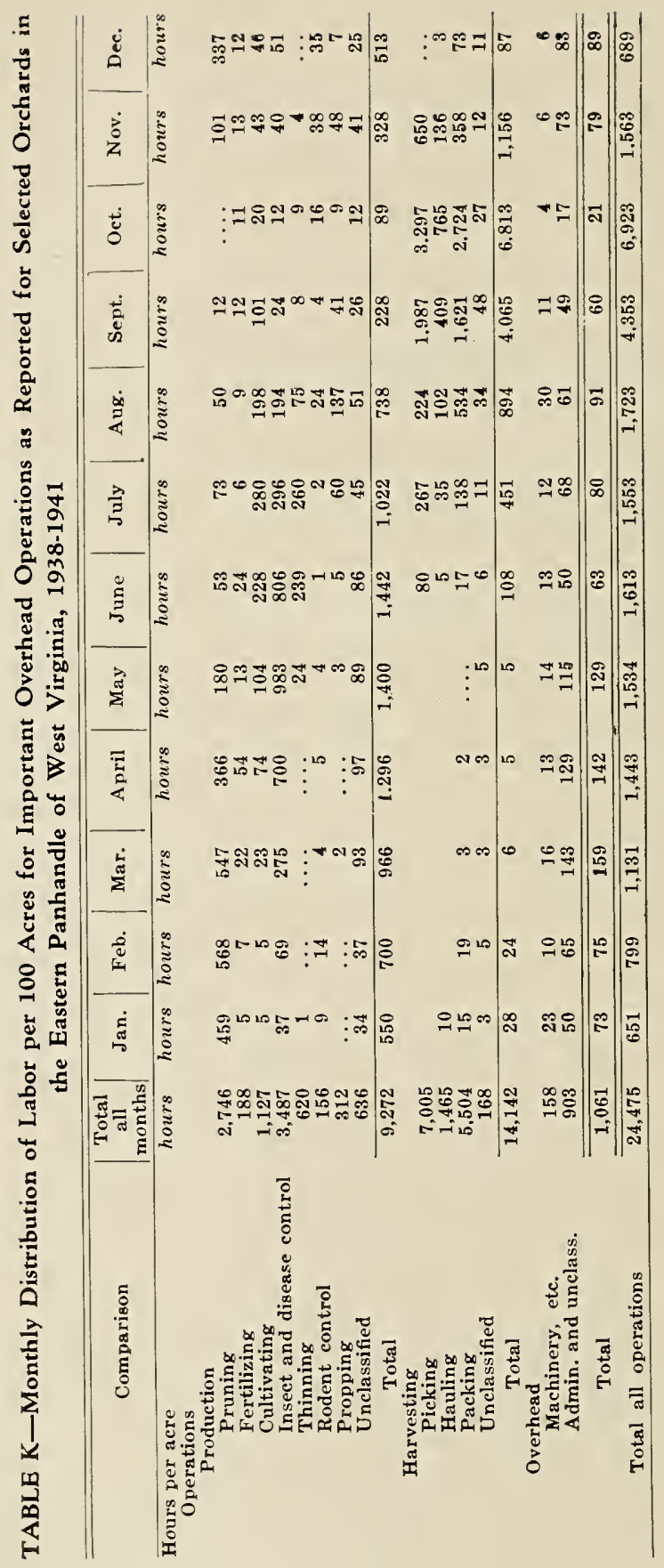




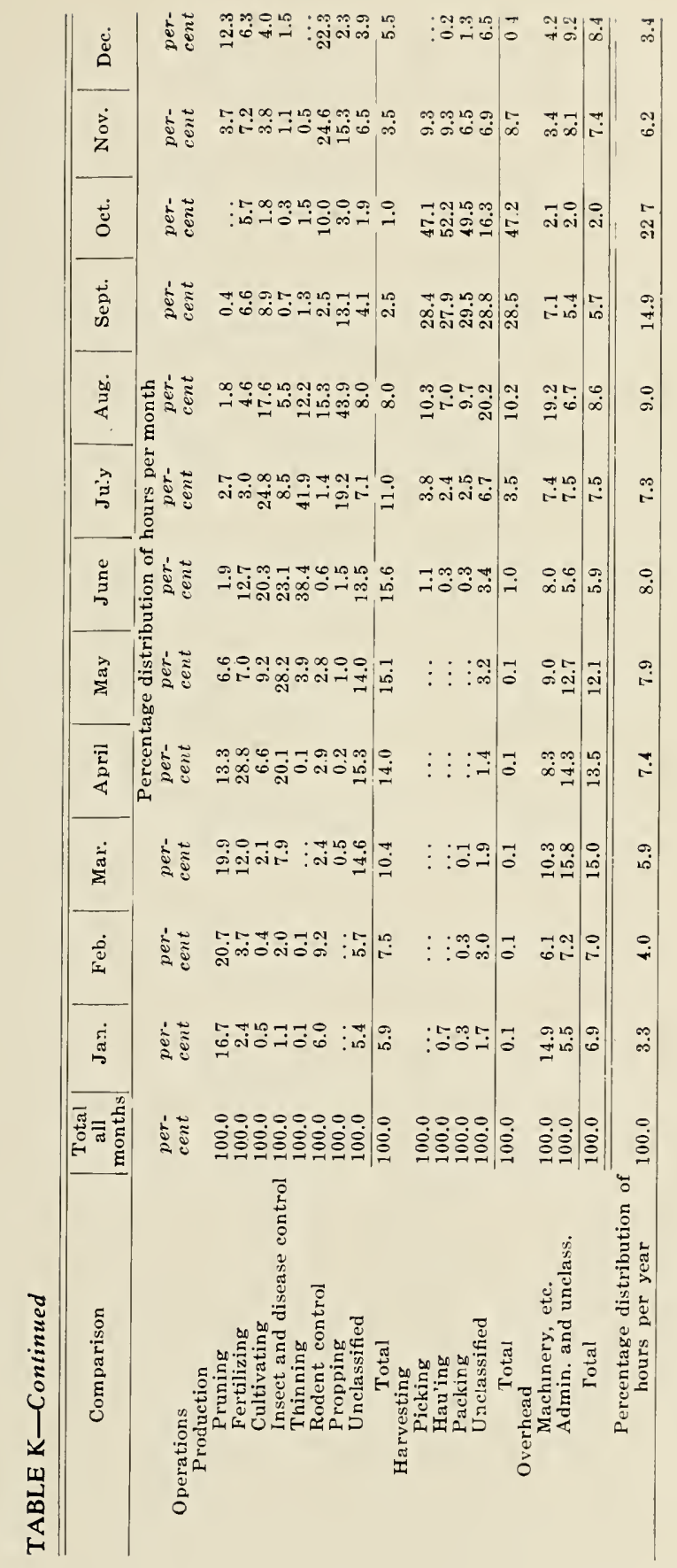



r 

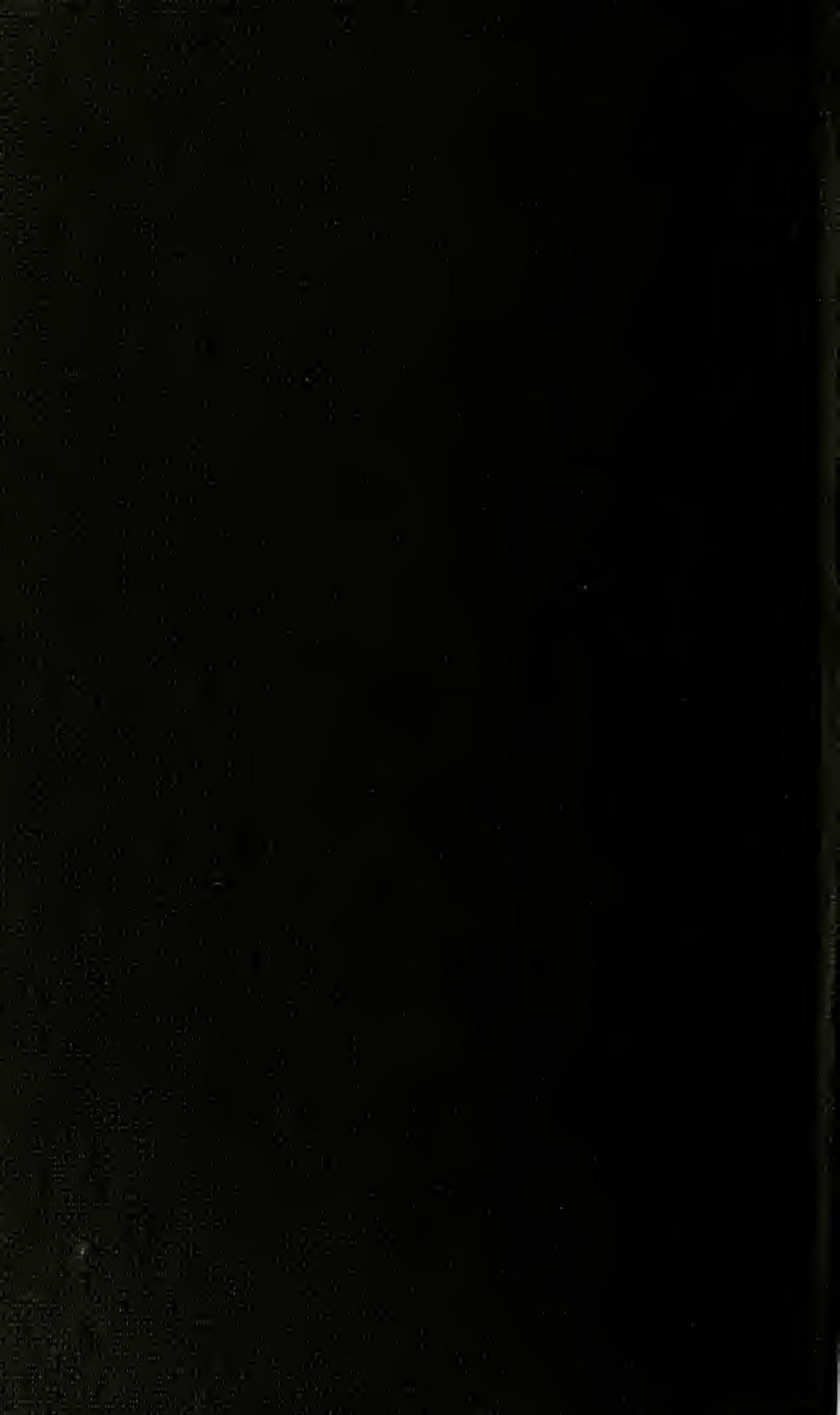